UNIVERSIDADE DE SÃO PAULO

FACULDADE DE FILOSOFIA, LETRAS E CIÊNCIAS HUMANAS

PROGRAMA DE PÓS-GRADUAÇÃO EM GEOGRAFIA FíSICA

VARIABILIDADE CLIMÁTICA E SUA INFLUÊNCIA NA

PRODUTIVIDADE DA CULTURA DO MILHO NA MICRORREGIÃO DE

FEIRA DE SANTANA (BAHIA)

ALINE FRANCO DINIZ

São Paulo

2016 


\title{
VARIABILIDADE CLIMÁTICA E SUA INFLUÊNCIA NA PRODUTIVIDADE DA CULTURA DO MILHO NA MICRORREGIÃO DE FEIRA DE SANTANA (BAHIA)
}

\begin{abstract}
Tese apresentada ao Programa de PósGraduação em Geografia Física da Faculdade de Filosofia, Letras e Ciências Humanas da Universidade de São Paulo, como requisito parcial para a obtenção do título de Doutor (a) em Geografia.
\end{abstract}

Orientador: Profo. . Dr. Emerson Galvani

São Paulo 
Autorizo a reprodução e divulgação total ou parcial deste trabalho, por qualquer meio convencional ou eletrônico, para fins de estudo e pesquisa, desde que citada a fonte.

Catalogação na Publicação

Serviço de Biblioteca e Documentação

Faculdade de Filosofia, Letras e Ciências Humanas da Universidade de São Paulo

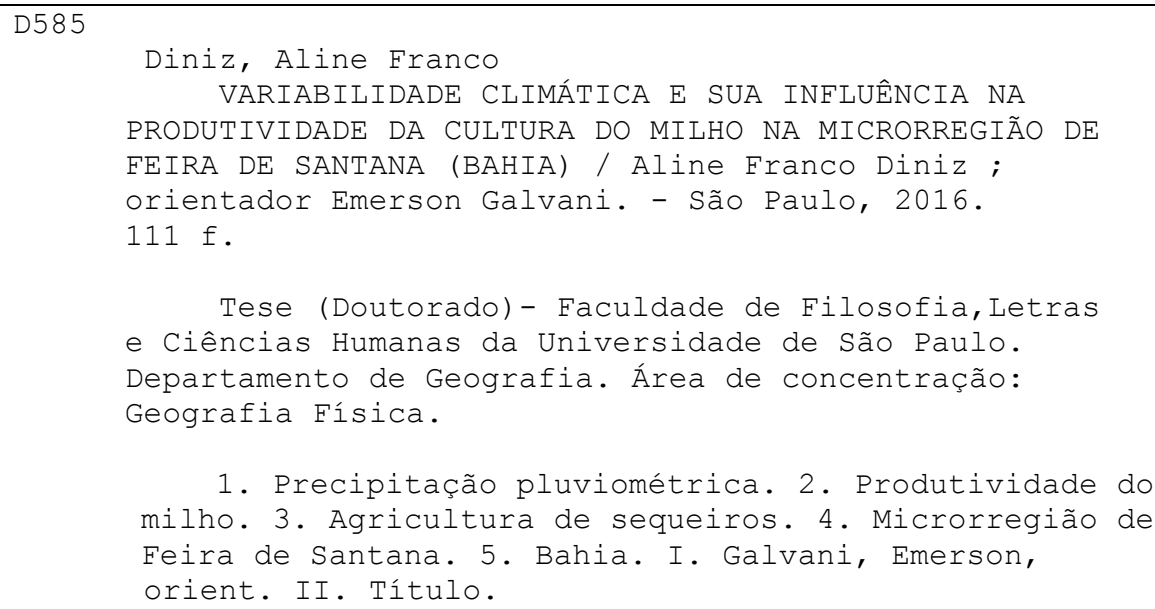

1. Precipitação pluviométrica. 2. Produtividade do milho. 3. Agricultura de sequeiros. 4. Microrregião de Feira de Santana. 5. Bahia. I. Galvani, Emerson, orient. II. Título. 
"Que nada nos limite, que nada nos defina, que nada nos sujeite. Que a liberdade seja nossa própria substância, já que viver é ser livre" Simone de Beauvoir 


\section{DEDICATÓRIA}

Com muita gratidão, dedico esse trabalho à minha família, ao meu orientador Emerson Galvani, aos meus companheiros e companheiras de luta, e aos pequenos agricultores do estado da Bahia. 


\section{AGRADECIMENTOS}

Um curso de Doutorado é um projeto de vida e de amadurecimento.

Este trabalho aqui apresentado representa a principal etapa da minha vida acadêmica, política e pessoal. Apesar de inúmeros desafios e obstáculos eu agradeço as inúmeras pessoas por terem me dado força, coragem e perseverança para nesses últimos quatros anos.

A minha família de mulheres. Agradeço em especial a minha amada mãe Rosa, por ter criado suas filhas sozinhas no interior da Bahia, minha maior companheira de vida. Obrigada por todo amor ao longo dos meus 31 anos. A minha irmã Karol e minha sobrinha Keyse, amores da minha vida. E a minha Vó Ester por todo apoio durante tantos anos. Minha eterna gratidão.

Agradeço aos meus tios e tias, aos meus primos e primas, e ao meu companheiro Gabriel por ter me proporcionado equilíbrio, confiança e alegrias nesses últimos meses.

Agradeço ao meu orientador Professor Emerson Galvani a quem dedico um agradecimento muito especial e de coração. Obrigada pelos ensinamentos, pela motivação, pela paciência e por ter compartilhado seus conhecimentos científicos e de vida comigo. Obrigada por não ter desistido de mim. Minha eterna admiração e gratidão!

Agradeço a Universidade de São Paulo, ao Departamento de Geografia, Secretaria da Pós-Graduação em Geografia Física, aos professores e professoras, funcionários e funcionárias e amigos e amigas da Pós-Graduação em Geografia Física desta Instituição, ao Laboratório de Climatologia e Biogeografia e à concessão de bolsa de estudo do CNPQ que possibilitou o financiamento desta pesquisa. 
Um agradecimento especial a Professora Ivonete de Almeida Souza Domingues e ao Professor José Bueno Conti pelas orientações acadêmicas e por participar de todas as etapas de desenvolvimento da pesquisa. Muito obrigada!

A minha família cruspiana. Foram quatros anos morando no Crusp (Conjunto Residencial da USP), maior moradia estudantil da Ámerica Latina, na qual fui diretora e tesoureira (gestão 2015-2016). Esses anos me trouxeram um amadurecimento pessoal e político. Estive ao lado de grandes amigos e amigas, companheiros e companheiras de luta. Não irei citar nomes aqui, para não correr riscos de esquecer alguém especial. Realizamos incansáveis lutas por permanência estudantil, carrego comigo a solidariedade e sensibilidade para com o outro. Por um Crusp Independente e de Luta!

Aos companheiros e companheiras da ANPG (Associação Nacional de PósGraduandos) durante nossa gestão (2014-2016), e a nossa atual gestão. Aos companheiros e companheiras da APG (Associação de Pós-Graduandos) Usp Capital durante nossa gestão (2014-2015). Aos amigos e amigas da gestão Amorcrusp Independente e de Luta (gestão 2015-2016), uma saudação especial. Ao nosso comitê "Usp Contra o Golpe". Aos companheiros e companheiras petistas da USP. A Representação Discente da Geografia Física durante meus dois mandatos (2014-2015/2015-2016). Uma saudação especial ao coletivo dos estudantes da USP "Independente e de Luta" que ajudei a construir em 2015. 


\section{RESUMO}

O elemento climático, precipitação pluviométrica, apresenta grande variabilidade espacial no Nordeste brasileiro, uma vez que, a ausência ou frequência das chuvas são responsáveis pelo desempenho da agricultura de sequeiros. Com isso, destaca-se o papel do clima como condicionante do processo produtivo, nos quais se procura desvendar as condições climáticas na tentativa de entender sua dinâmica, e com o interesse de aperfeiçoar as possibilidades de cultivo nos mais variados espaços. Com este trabalho objetivou-se estudar a relação entre a precipitação pluviométrica nos municípios de Teodoro Sampaio, Feira de Santana e Rafael Jambeiro, no período de 1990 a 2010, e seus reflexos na produtividade do milho. A relevância deste trabalho está na importância dos estudos agroclimatológicos, a partir da contribuição dos estudos realizados no campo da climatologia agrícola, sob o prisma da climatologia geográfica. Os conceitos norteadores para o desenvolvimento desta pesquisa são precipitação pluviométrica e produtividade agrícola. Para tanto, foram consultados diversos trabalhos, a fim de embasar o processo de construção do referencial teórico-conceitual, podendo ser destacados Ayoade (1983); Christofoletti (1989); Nimer (1989), Santos (2000), Sant'Anna Neto (2003), Tavares (2004) e Domingues (2010). Os estudos foram realizados a partir dos dados de precipitação pluviométrica disponibilizados pela Agência Nacional de Águas (ANA) e os dados de produtividade agrícola do milho disponibilizado pelo Instituto Brasileiro de Geografia e Estatística (IBGE) para a mesma série temporal. Foi possível perceber dentro da série histórica que alguns anos apresentaram uma relação direta entre os desvios de chuvas com a produtividade do milho, ficando bastante claro que alguns desvios negativos de chuvas foram coincidentes com os desvios negativos de produtividade, porém a correlação entre os desvios de precipitação e produtividade do milho realizada para os três municípios foi pouca significativa.

Palavras-chave: precipitação pluviométrica; produtividade do milho; agricultura de sequeiros. 


\begin{abstract}
The climatic element rainfall has great spatial variability in Northeast Brazil, since the absence or frequency of rainfall are responsible for the performance of sequeiros agriculture. Thus, there is the role of climate as a condition of the production process, in which it seeks to discover the climatic conditions in an attempt to understand its dynamics, and the interest of improving the cultivation possibilities in various spaces. This work aimed to study the relationship between rainfall in the Teodoro Sampaio, Feira de Santana and Rafael Jambeiro counties, from 1990 to 2010, and its effects on maize yields. The relevance of this work is the importance for agroclimatology studies, from the contribution of studies in the field of agricultural climatology, in the light of the geographical climatology. The guiding concepts for the development of this research are rainfall and agricultural productivity. Therefore, several works were consulted in order to base the process of building the theoretical and conceptual framework can be highlighted Ayoade (1983); Christofoletti (1989); Nimer (1989), Santos (2000), Sant'Anna Neto (2003), Tavares (2004) and Domingues (2010). The studies were conducted from rainfall data provided by the Agência Nacional de Águas (ANA) and agricultural productivity data corn provided by the Instituto Brasileiro de Geografia e Estatística (IBGE) for the same time series. It could be observed in the time series a few years showed a direct relationship between rainfall deviations maize yield, getting quite clear that some negative deviations of rainfall coincided with the negative deviations of productivity, but the correlation between the deviations rainfall and maize yields held for the three counties was little significant.
\end{abstract}

Keywords: rainfall; maize yields; sequeiros agriculture. 


\section{LISTA DE SIGLAS E ABREVIAÇÕES}

ASAN - Anticiclones Subtropicais do Atlântico Norte

ASAS - Anticiclones Subtropicais do Atlântico Norte

ATN - Atlântico Tropical Norte

CEI - Centro de Estatísticas e Informações

CEPLAB - Centro de Planejamento da Bahia

CONAB - Companhia Nacional de Abastecimento

EMBRAPA - Empresa Brasileira de Pesquisa Agropecuária

ENOS - El Niño/Oscilação Sul

FPA - Frente Polar Atlântica

IBGE - Instituto Brasileiro de Geografia e Estatística

INPE - Instituto Nacional de Pesquisas Espaciais

NEB - Nordeste do Brasil

SEPLANTEC - Secretaria do Planejamento, Ciência e Tecnologia

SFs - Sistemas Frontais

SEI - Superintendência de Estudos Econômicos e Sociais da Bahia

SUDENE - Superintendência do Desenvolvimento do Nordeste

TSM - Temperatura da Superfície do Mar

ZCA - Zona de Confluência dos Alísios

ZCIT - Zona de Convergência Intertropical 


\section{INTRODUÇÃO}

O clima constitui, apesar do grande avanço tecnológico e científico, uma importante variável na produtividade agrícola, uma vez que está diretamente relacionado com a agricultura através de elementos climáticos sobre as lavouras e através do controle exercido pelo clima sobre os tipos de práticas agrícolas e de cultivos mais adequados para cada área. Os elementos climáticos exercem influência sobre todos os estágios da produtividade agrícola, desde a preparação da terra, semeadura, crescimento e colheita.

A relação entre clima e organização do espaço depende do grau de desenvolvimento econômico e tecnológico de cada sociedade em particular e de quais atributos são fundamentais em cada ecossistema do planeta. No caso da agricultura, é importante considerar o clima como insumo da produtividade agrícola.

$\mathrm{Na}$ agricultura, ao se considerar o clima (e seus elementos) como insumo da produtividade agrícola, pretende-se afirmar que seu papel não é o de determinante no sistema, mas sim, o de regulador do processo (tanto quanto ao capital, a tecnologia e o trabalho humano). Isto significa que, quanto maior for à possibilidade de inversão de capital e maior a possibilidade de utilização e sofisticação da tecnologia, menor a dependência dos fatores do clima.

Desta forma, devemos considerar que vivemos em uma sociedade repleta de desigualdades e, conforme Sant'Anna Neto (2001, p. 157), "a repercussão dos fenômenos atmosféricos na superfície terrestre se dá num território, transformado e produzido pela sociedade, de maneira desigual e apropriado segundo os interesses dos agentes sociais", nos levando a entender que, 
dependendo do modo de apropriação do território, associado à variabilidade intrínseca do fenômeno climático, promove-se o desenvolvimento também desigual da agricultura.

Esse fato faz com que algumas áreas produtoras apresentem maior vulnerabilidade com relação à variabilidade climática do que outras, pois, dependendo de sua intensidade ao longo do tempo e do espaço, pode representar grandes perdas ao pequeno agricultor, descapitalizado e sem acesso às novas tecnologias. Por outro lado, pode não atingir com a mesma magnitude os grandes agricultores, detentores de grande capital e de tecnologias. Assim, inseridos no modo de produção capitalista, os agricultores melhores servidos de capital e de sofisticação tecnológica apresentam menores níveis de dependência das condições climáticas e, consequentemente, sua produção se dá sob uma menor vulnerabilidade.

O estudo da variabilidade climática e de sua influência na agricultura vem sendo a cada dia mais valorizado, com vistas à obtenção de mais e melhores conhecimentos científicos e tecnológicos necessários a uma produção agrária sustentável. Ou seja, cresce a convicção de que é preciso entender e priorizar as condições climáticas, para que se possa produzir cada vez mais em áreas agricultável cada vez mais reduzida (DOMINGUES, 2010).

Isso porque, ao se objetivar uma produtividade compensadora, deve-se levar em conta que cada cultura necessita de condições favoráveis durante todo o seu ciclo vegetativo, exigindo determinados limites de temperatura nos vários estádios do ciclo, uma quantidade mínima de água e um período seco no estádio de maturação e colheita. 
Nos primeiros séculos da colonização não havia lugar para a pequena propriedade na economia brasileira, voltada, então exclusivamente para a exploração em larga escala de produtos de alto valor comercial como o algodão, o café, a borracha e o cacau. As condições econômicas fundamentais no país e a estrutura social que sobre elas se constituíra tornava evidentemente inviável uma organização agrária, democrática e de larga repartição da propriedade fundiária.

No Nordeste brasileiro a forma de agricultura predominante é de subsistência, praticada em pequenas propriedades rurais nas condições de sequeiros, em que a produtividade agrícola depende da distribuição das chuvas e da fertilidade natural dos solos, nessas condições, os solos se apresentam erodidos, pobres em nutrientes e com níveis baixos de matéria orgânica. A expressão sequeiros deriva da palavra seco, e seu plantio em grande parte em regiões subdesenvolvidas é de forma extensiva.

A relação entre clima e organização do espaço depende do grau de desenvolvimento econômico e tecnológico de cada sociedade em particular. A modernização da agricultura está vinculada ao desenvolvimento tecnológico, este se processa de forma heterogênea no espaço geográfico, isto resulta na (re) produção deste espaço, aonde coexiste técnicas rudimentares ao lado de áreas modernas.

A agricultura moderna no Brasil se configura através dos latifúndios que são grandes propriedades de terras, provocando inúmeras transformações socioespaciais como a espacialização da produção; mudanças nas relações de trabalho; (re) organização produtiva, e divisão social e territorial do trabalho. Por outro lado, a agricultura familiar constitui-se como uma forma de produção 
em que o núcleo de decisões, gerência, trabalho e capital é exercido diretamente pela família. Em geral, são agricultores com baixo nível de escolaridade, que diversificam os produtos cultivados para diluir custos, aumentar a renda, aproveitar a disponibilidade de mão de obra. Por ser diversificada, a agricultura familiar traz benefícios socioeconômicos e ambientais.

É válido salientar que a agricultura familiar não deve ser tratada pelo ângulo da pobreza rural, ou simplesmente ser definida pelo tamanho do estabelecimento. A definição desse segmento passa pela análise das relações sociais que ocorrem entre a família, a terra e a produção, ou seja, predomínio da mão de obra familiar, equilíbrio entre produção, consumo e capacidade decisória do núcleo familiar sobre a administração do estabelecimento (SANTOS, 2007).

\subsection{PROBLEMÁTICA DA PESQUISA}

Esta pesquisa analisou a variabilidade pluviométrica, que se apresenta relevante para a agricultura de sequeiros, o que ressalta a importância de pesquisas desta natureza. Apesar da complexidade dos eventos atmosféricos e suas correlações, e em especial o elemento climático precipitação pluviométrica, esta tem grande destaque no Nordeste brasileiro, pois é o elemento que apresenta maior variabilidade espacial, uma vez que, se parte do pressuposto que a ausência ou frequência das chuvas são em parte responsáveis pelo desempenho da agricultura no estado da Bahia. 
Desta forma, este trabalho realizou um estudo sobre a precipitação pluviométrica e a sua repercussão na agricultura de sequeiros na microrregião de Feira de Santana, especificamente na cultura do milho. Para investigar o tema proposto foi necessária a formulação de alguns questionamentos:

i) Qual foi a tendência da variabilidade pluviométrica na microrregião de Feira de Santana a partir das análises de 21 anos de estudos, na série temporal compreendida entre 1990 a 2010 e a sua relação com a produtividade agrícola do milho?

ii) Ao longo dos 21 anos foi possível perceber uma ciclicidade entre distribuição das chuvas e a organização da agricultura familiar na microrregião de Feira de Santana?

\subsection{HIPÓTESE}

O milho é uma cultura que exige calor e umidade para se desenvolver satisfatoriamente. As precipitações pluviométricas devem ser em torno de 200 $\mathrm{mm}$ no inverno, para que a referida cultura venha se desenvolver. De modo geral, a variabilidade climática interfere na cultura do milho, resultando em uma produtividade heterogênea dentro da microrregião de Feira de Santana.

A hipótese levantada por este trabalho é se na microrregião de Feira Santana a precipitação pluviométrica no período entre 1990 a 2010 define a produtividade do milho. 


\subsection{OBJETIVOS}

\subsubsection{Geral}

O objetivo geral desta pesquisa foi estudar a relação entre a precipitação pluviométrica na microrregião de Feira de Santana, no período entre 1990 a 2010, e seus reflexos na cultura do milho, identificando as correlações entre a chuva e a produtividade agrícola.

\subsubsection{Específicos}

$\checkmark$ Analisar os dados pluviométricos anuais compreendidos entre 1990 a 2010 na microrregião de Feira de Santana, especificamente nos municípios de Teodoro Sampaio, Feira de Santana e Rafael Jambeiro com a produtividade agrícola do milho no mesmo período.

$\checkmark$ Realizar a correlação entre a precipitação pluviométrica e a produtividade do milho nos municípios de Teodoro Sampaio, Feira de Santana e Rafael Jambeiro, e a partir dessas informações analisar os efeitos da precipitação pluviométrica na cultura do milho no período de 1990 a 2010.

\subsection{JUSTIFICATIVA}

O estado da Bahia tem cerca de $320.211 \mathrm{~km}^{2}$, ou $57,08 \%$ do território inserido no Polígono das Secas, constituindo 33\% da área total deste Polígono. 
A microrregião de Feira de Santana está inserida no Polígono das Secas, pois compartilha fatores comuns da problemática nordestina, do ponto de vista climático, apresentando características peculiares como períodos de secas.

Este trabalho se justificou por analisar a precipitação pluviométrica da microrregião de Feira de Santana e a sua relação com a produtividade agrícola. A escolha desta microrregião é pela importância geográfica, histórica e econômica para o estado da Bahia. Além disso, é importante ressaltar que a sede do município de Feira de Santana corresponde a segunda maior cidade do estado com relação à população absoluta de aproximadamente 612.000 habitantes (IBGE, 2014), perdendo apenas para a capital, Salvador. A escolha da microrregião de Feira de Santana como objeto da análise, diante da especificidade do estado, tanto no que se refere à extensão territorial (564.692,7 km²), quanto ao número de municípios (quatrocentos e dezessete), é por conta da dificuldade de uma análise mais detalhada da totalidade do estado da Bahia.

A atividade produtiva, propalada como meio para alcançar 0 desenvolvimento regional/territorial, é efetivada no perímetro da Região Metropolitana de Salvador (RMS), mas, a partir de então, desloca-se em direção ao sertão e, no espaço baiano, registram-se novas articulações espaciais, especialmente quando o processo atinge a microrregião Feira de Santana.

A microrregião de Feira de Santana é composta por 24 municípios, mas Feira de Santana exerce um papel fundamental no que diz respeito à centralização e concentração das atividades econômicas. Em 2007 as estimativas do IBGE, apontavam para quase um milhão de habitantes, 
residindo numa área correspondente a 12.646, $80 \mathrm{~km}^{2}$, e o município de Feira de Santana detém mais de $50 \%$ da população.

A atividade econômica que predomina na microrregião é o comércio, agricultura, pecuária e a indústria. Dentre os cultivos agrícolas se destacam o milho, feijão e a mandioca. O milho apresenta a maior produtividade agrícola na área de estudo, por isso a sua escolha para esta pesquisa.

A relevância deste trabalho está na importância dos estudos agroclimatológicos, a partir da contribuição dos estudos realizados no campo da climatologia agrícola, sob o prisma da climatologia geográfica, subsidiando as discussões que envolvem clima e agricultura. Além disso, este tema apresentou-se pertinente, devido aos fatos que justificam e dão consistências a escolha do tema proposto para o desenvolvimento deste trabalho bem como do seu universo de análise. 


\section{CARACTERIZAÇÃO DA ÁREA DE ESTUDO}

A área de estudo desta pesquisa é a microrregião de Feira de Santana, que está localizado no estado da Bahia. É formada pelos municípios de Água Fria, Anguera, Antônio Cardoso, Conceição da Feira, Conceição do Jacuípe, Coração de Maria, Elísio Medrado, Feira de Santana, Ipecaetá, Ipirá, Irará, Itatim, Ouriçangas, Pedrão, Pintadas, Rafael Jambeiro, Santa Bárbara, Santa Teresinha, Santanópolis, Santo Estêvão, São Gonçalo dos Campos, Serra Preta, Tanquinho e Teodoro Sampaio. Desse universo de municípios trabalhouse em especifico com dados de três deles, a saber: Feira de Santana, Rafael Jambeiro e Teodoro Sampaio. A microrregião de Feira de Santana está inserida na mesorregião Centro-Norte Baiano, possui uma área geográfica de $12.602,6 \mathrm{~km}^{2}$ (Figura 01).

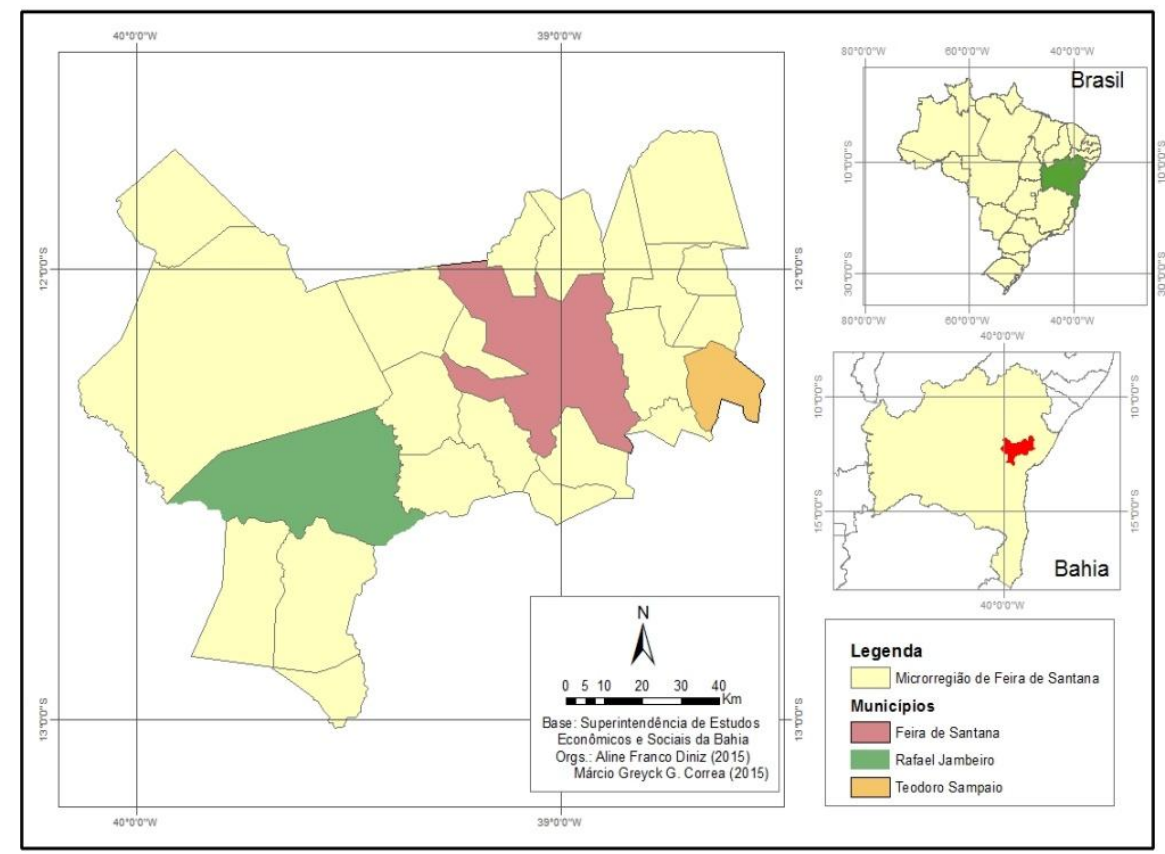

Figura 01: Localização da área de estudo (microrregião de Feira de Santana - Bahia, em destaques os municípios em estudo: Feira de Santana, Rafael Jambeiro e Teodoro Sampaio).

Fonte: SEI (2012)

Elaboração: DINIZ e CORREA (2015) 
Segundo Freitas (2010) a formação territorial de Feira de Santana esteve vinculada à expansão da pecuária, que se consolidou a partir do final do século XVIII. Até então, a feira de gado mais importante do estado da Bahia era a de Capuame no norte do recôncavo; suas pastagens, porém, foram substituídas pelos canaviais, perdendo a região suas características. Abre-se, com isso, um novo espaço para a expansão daquela atividade produtiva, e Feira de Santana transformou-se em importante centro de comercialização de produtos oriundos da pecuária e principal feira de gado do estado, já no ano de 1828 aproximadamente.

A aglomeração urbana que se desenvolveu nas proximidades da capela da Fazenda Sant'Ana dos Olhos d'Água se beneficiou da busca de pastagens e da tentativa de penetração para o interior, consolidando um processo de urbanização. De origem relativamente recente, se comparada ao processo de formação territorial da Bahia, Feira de Santana foi considerada uma unidade política em 1873. Desde 1693 fazia parte da Comarca de Cachoeira, sendo elevada à categoria de Freguesia no ano de 1696. No início do século XIX, Feira de Santana já era "povoada" e considerada o "maior arraial da Paróquia de São José das Itapororocas", passando à categoria de povoado em 1819: até então, Cachoeira era a segunda maior cidade do estado (POPPINO, 1968).

Em 13 de novembro de 1832, o povoado passou à categoria de vila, mediante decreto imperial. A sede do município correspondeu a uma área de 12 mil quilômetros, desligada do município de Cachoeira e também escolhida para esta situação por ser a maior região e a mais importante do ponto de vista econômico. Naquele período, a quase totalidade da produção agrícola e pastoril da região era comercializada na feira, antes de seguir para a capital. 
Em 16 de junho de 1873, a vila foi elevada à categoria de cidade com a denominação de Cidade Comercial de Feira de Santana. Desde então, ampliou seu papel em nível local/regional, sendo o setor terciário o mais expressivo economicamente. O comércio de gado foi realizado no "Campo do Gado ou da Gameleira" que se localizava a aproximadamente um quilômetro ao norte da Capela de Santana, fortalecendo as atividades comerciais do centro (POPPINO, 1968).

Freitas (2010) acrescentou que atualmente Feira de Santana constitui-se como centro comercial de médio porte, com influência marcante em nível local/regional, posicionando-se como segunda maior cidade do estado e, desde a data de sua emancipação, adquiriu expressividade no cenário econômico da Bahia. Este município funciona como ponto de passagem para diferentes destinos, devido às rodovias: BR-324, BR-101 e BR-116.

O Centro Industrial do Subaé é outro elemento marcante para formação territorial. Criado através da Lei Municipal no 690, em 14 de dezembro de 1970, é constituído por dois distritos industriais, um deles instalado no bairro do Tomba, área que se situa na parte sul da cidade e também responsável pelo acesso à BR-101 e, o outro, às margens da BR-324, em contato direto com a capital; ocupa, portanto, Feira de Santana uma posição privilegiada, por ser considerada o maior entroncamento rodoviário do Norte-Nordeste do país. Tal formação está diretamente ligada à história da pecuária e ao comércio do gado da Bahia (FREITAS, 2010).

Os primeiros povoadores eram criadores e a Fazenda Santana dos Olhos d'Água era pouso obrigatório de antigos tropeiros que levavam o rebanho em direção a Salvador, além de comercializar, no local, uma parte do 
mesmo. As vantagens locacionais, de intermediária entre o recôncavo e o sertão baiano, fazem com que a cidade funcione como entreposto comercial, ocorrendo uma rápida expansão do comércio que, com o advento do rodoviarismo, favoreceu o contato com outras regiões (FREITAS, 2010).

Com relação aos aspectos naturais da microrregião de Feira de Santana, no que diz respeito à sua hidrografia, está situada na sub-bacia do rio Jacuípe, na margem esquerda. A drenagem principal é constituída pelos rios Jacuípe, Pojuca e Subaé que integram a bacia do Paraguaçu no seu baixo curso e o regime fluvial têm caráter intermitente na maioria dos seus cursos d água (SANTO, 1995).

Na bacia do Paraguaçu o clima Semi-Árido predomina com 67\%, já nas intermediações da Chapada Diamantina, o clima torna-se mais ameno mudando para o tipo Subúmido a Seco, com algumas pequenas áreas na nascente do rio Paraguaçu apresentando um clima Úmido a Subúmido. E quando os totais pluviométricos aumentam, atingindo até $1200 \mathrm{~mm}$ na bacia do Paraguaçu o clima predominante é o Úmido a Subúmido (INEMA, 2014).

Santo (1995) ao realizar um estudo sobre a hidrografia da área de estudo ressaltou que a ocupação humana cresceu de forma desordenada com aumento populacional excessivo, principalmente após 1970, e com o indevido acompanhamento da infraestrutura urbana. Ao passar do tempo, as lagoas se tornaram áreas consideradas como alternativas para ocupação humana, sendo-as aterradas para as construções residenciais e comerciais, além dos despejos de efluentes poluidores advindos de esgotos urbanos.

A área de estudo é constituída geologicamente por dois grandes conjuntos litológicos: o embasamento cristalino datado do pré-cambriano, 
formado por granitóides, granulitos e migmatitos, e a unidade de cobertura sedimentar (Quaternária) formada por areias e argilas variadas, com níveis conglomeráticos. Especificamente nos municípios em estudo: em Teodoro Sampaio predomina o arenito, no município de Feira de Santana prevalecem os gnaisses, e por último Rafael Jambeiro os anfibolitos e ortognaisses (Figura 02).

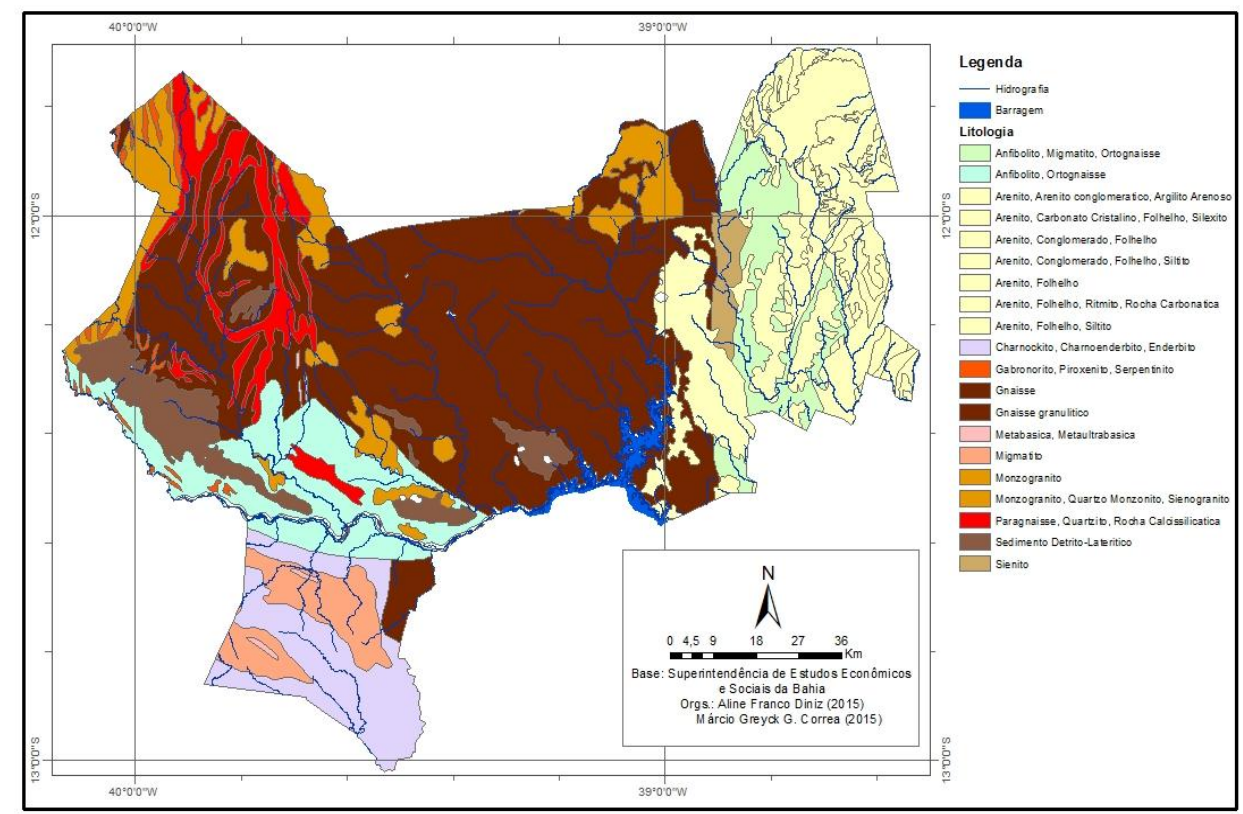

Figura 02: Litologia da área de estudo (Microrregião de Feira de Santana - Bahia) Fonte: SEI (2012).

Elaboração: DINIZ e CORREA (2015)

Com relação à geomorfologia segundo Souza e Santos (2014) a área de estudo está compartimentada em três superfícies denominadas cimeira, intermediária e inferior. A primeira corresponde aos Tabuleiros Interioranos, individualizados no Pediplano Sertanejo, sendo localmente denominado Tabuleiro de Feira de Santana, onde a formação Capim Grosso (Barreiras do Interior) repousa concordantemente sobre o embasamento cristalino, no qual formou pacotes sedimentares que variam de $1,5 \mathrm{~m}$ a $15 \mathrm{~m}$ de profundidade; as demais compõem a superfície exumada, localmente subdividida em função da 
escala e da história evolutiva. Nos municípios em estudo: Teodoro Sampaio predomina o Pediplano Sertanejo, no município de Feira de Santana prevalecem os Tabuleiros Interioranos, e por último Rafael Jambeiro os Pediplano Sertanejo e os Tabuleiros Interioranos (Figura 03).

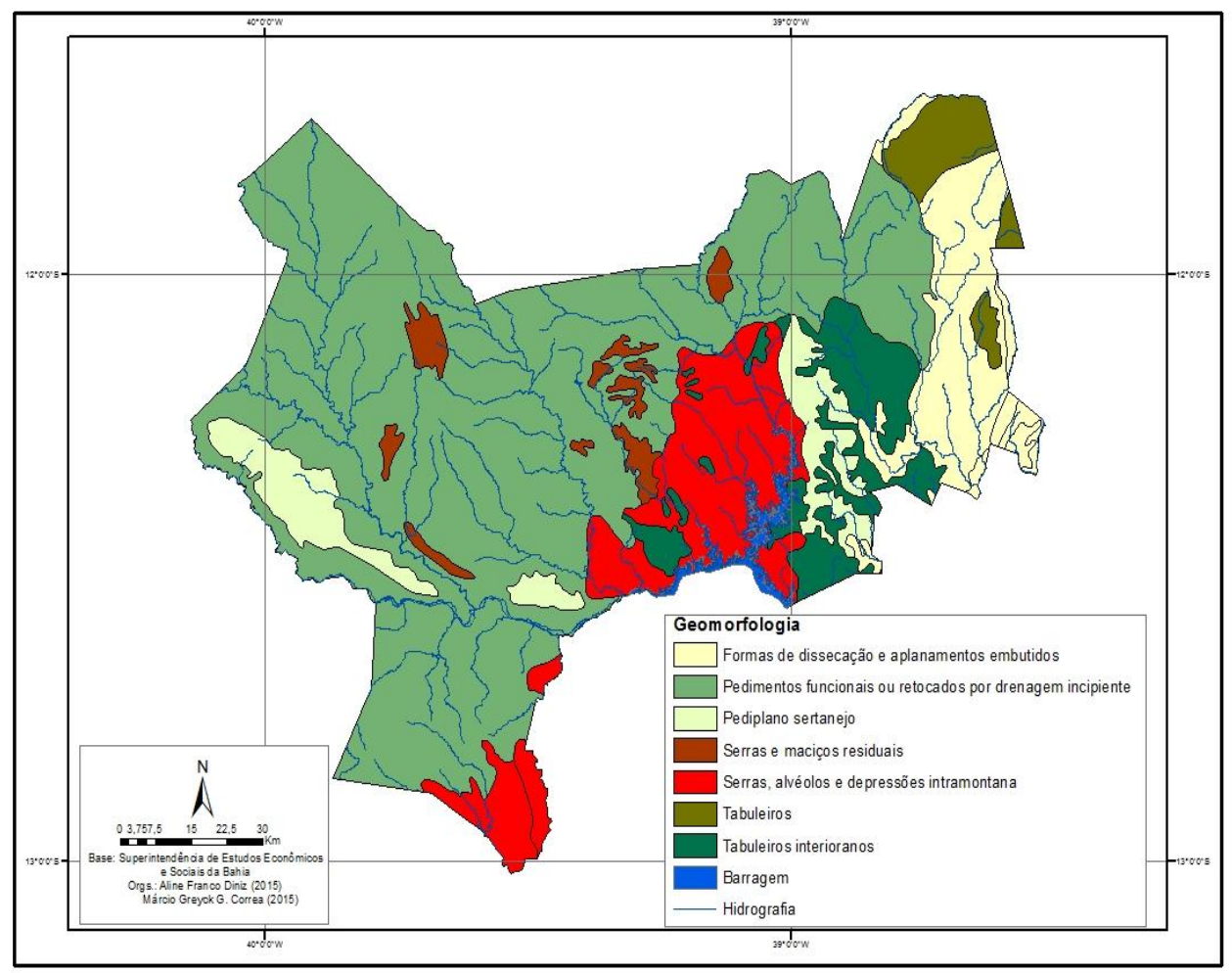

Figura 03: Geomorfologia da área de estudo (Microrregião de Feira de Santana Bahia).

Fonte: SEI (2012)

Elaboração: DINIZ e CORREA (2015)

A área de estudo apresenta relevo com reduzida declividade, caracterizando-se como uma região de tabuleiros pouco dissecados, onde as formações de datações Quaternárias e areno-argilosas (Formação Capim Grosso) depositaram-se semi-horizontalmente sobre o embasamento grandemente fraturado. Além disso, segundo Anjos (1968), a geomorfologia da microrregião em estudo está desenvolvida sobre os sedimentos da formação 
Barreiras, composta pelo sistema aqüífero granular livre, encontrado nas pequenas profundidades, que formam o planalto ligeiramente ondulado por morros testemunhos de rochas pré-cambrianas (embasamento cristalino), que por sua vez, forma o sistema aquífero fissural (Figura 03).

Com relação aos solos, de acordo com o 1ำ nível categórico da classificação dos solos (ordem), pelo Sistema Brasileiro de Classificação dos Solos da Empresa Brasileira de Pesquisa Agropecuária (EMBRAPA, 1999), na microrregião de Feira de Santana foram encontradas as seguintes classes de solos: ARGISSOLOS, CHERNOSSOLOS, LATOSSOLOS, NEOSSOLO, PLANOSSOLOS e VERTISSOLOS. Nos municípios em estudo: Teodoro Sampaio predominam os ARGISSOLOS e nos municípios de Feira de Santana e Rafael Jambeiro prevalecem os PLANOSSOLOS (Figura 04).

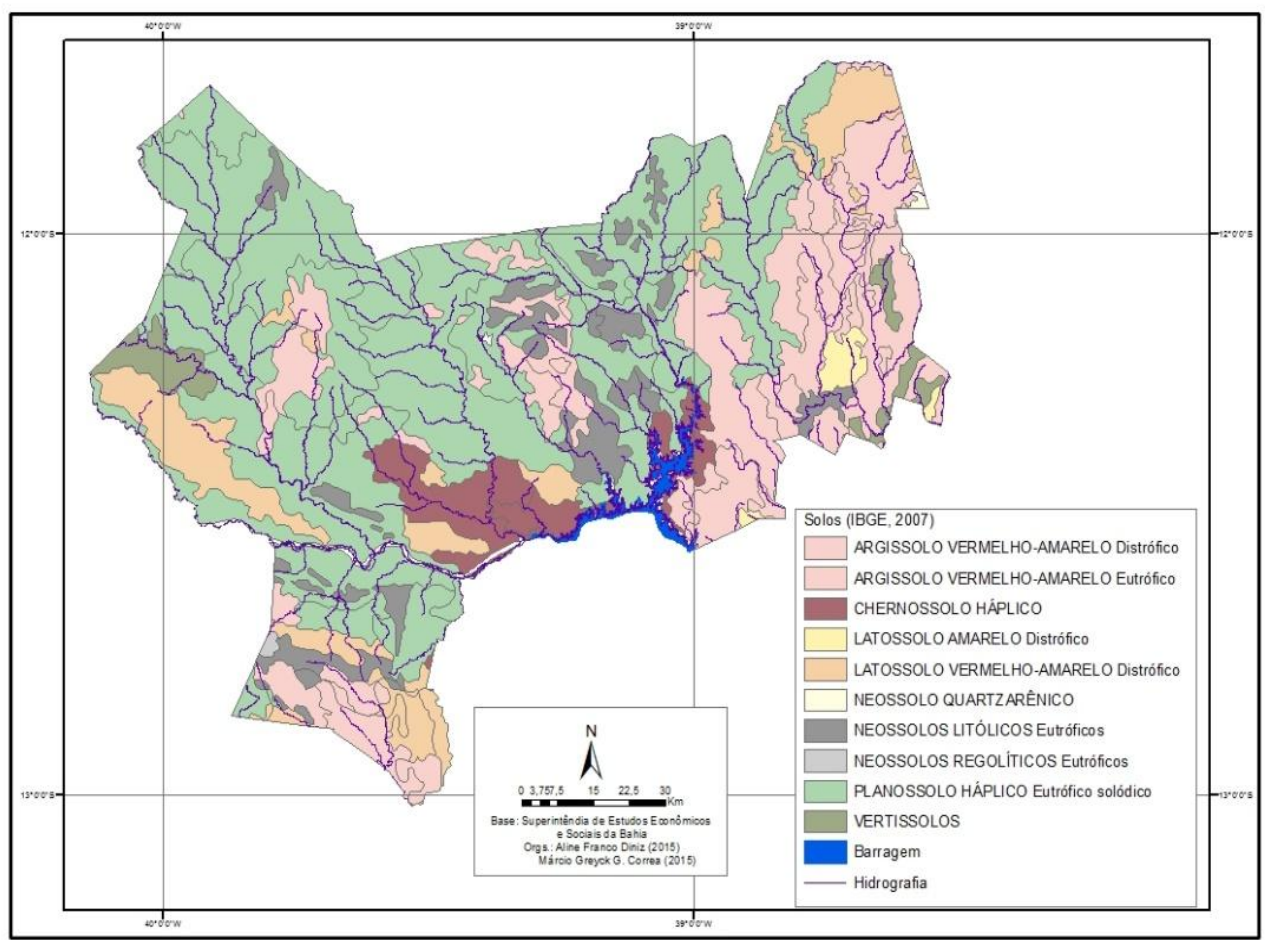

Figura 04: Solos da área de estudo (Microrregião de Feira de Santana - Bahia) Fonte: SEI (2012).

Elaboração: DINIZ e CORREA (2015) 
A área de estudo apresenta como bioma a caatinga que possui características muito peculiares e diversificadas. Caracteriza-se como formação xerófila, lenhosa, decídua, em geral espinhosa, com presença de plantas suculentas e estrato herbáceo estacional, além de uma ampla variação florística como os arbustos espinhosos e as gramíneas. A caatinga é constituída por árvores e arbustos espinhosos, que perdem suas folhas na estação seca, e se desenvolvem com bastante vigor após os períodos chuvosos. A vegetação é constituída no estrato mais alto por árvores e arbustos de porte médio, de 2,50 a 3,00 metros de altura, altamente ramificados. As plantas, geralmente, se agrupam em forma de pequenas ilhas, deixando entre si espaços sem qualquer vegetação, e geralmente as plantas são emolduradas por um amontoado de cactáceas. No estrato superior arbustivo são observados principalmente umbuzeiros, catingueira, jurema, marmeleiro e mandacaru. No estrato inferior, com até 50 centímetros de altura, é composto de poucas espécies de cactáceas como o xique-xique e o quipá (SOUTO, 2012). 


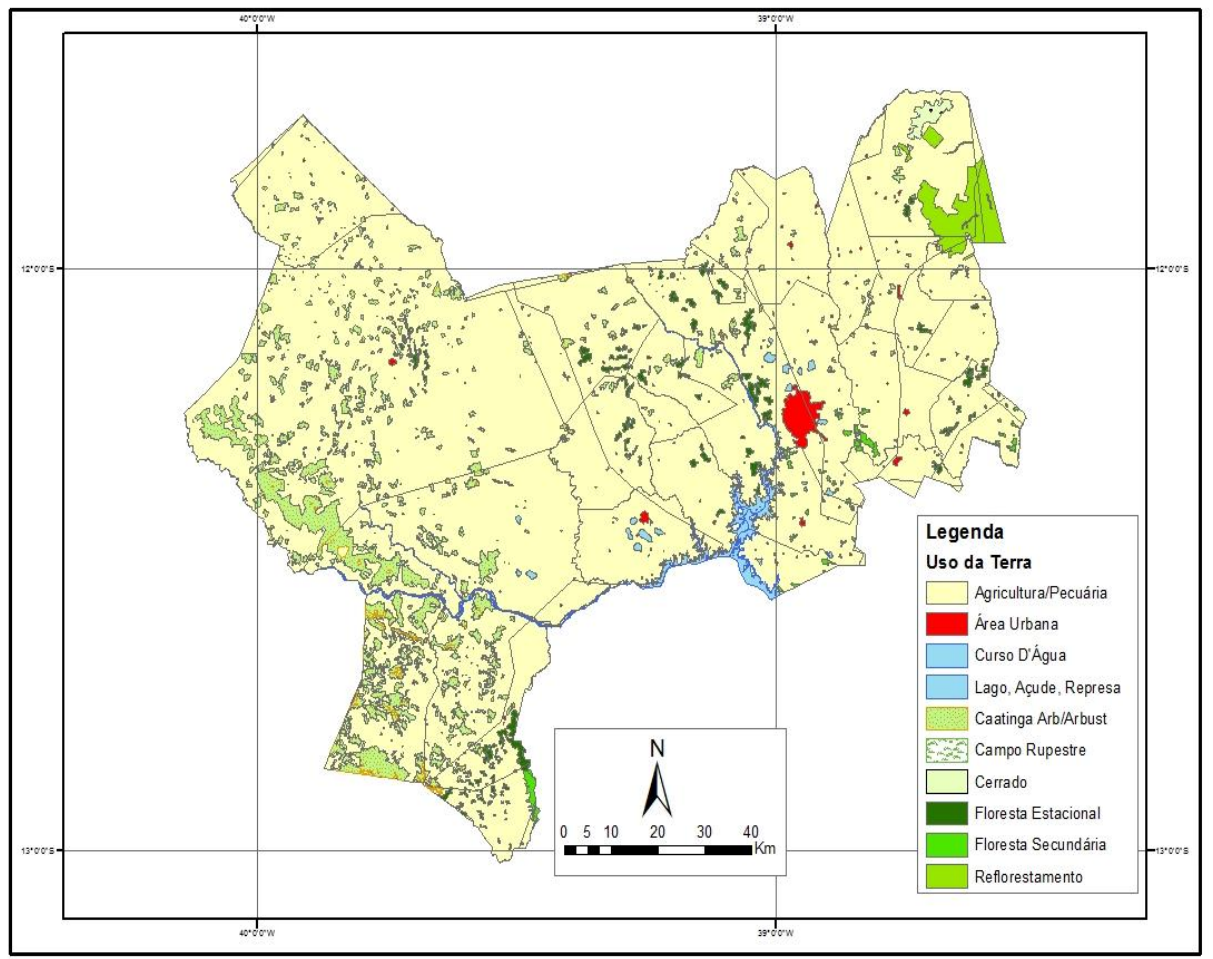

Figura 05: Uso da Terra da área de estudo (Microrregião de Feira de Santana - Bahia).

Fonte: SEI (2012)

Elaboração: DINIZ e CORREA (2015)

A elevada degradação que a caatinga vem sofrendo e os reduzidos números e dimensões de suas áreas de ocupação são condições preocupantes, do ponto de vista florístico e estrutural, uma vez que este bioma é bastante heterogêneo, e atualmente é considerada como o bioma menos preservado e um dos mais degradados. Desta forma, é muito importante a realização do manejo da caatinga, como forma de compatibilizar a exploração e a diversidade biológica. Nos municípios em estudo percebe-se a degradação da caatinga, e a respectiva presença da agricultura e pecuária (Figura 05). 


\subsection{CARACTERIZAÇÃO CLIMÁTICA DA ÁREA DE ESTUDO}

O Nordeste do Brasil (NEB) engloba os estados de Alagoas, Bahia, Ceará, Maranhão, Paraíba, Piauí, Pernambuco, Rio Grande do Norte e Sergipe, perfazendo uma área de $1.558 .196 \mathrm{~km}^{2}$, situando-se no nordeste da América do Sul e a leste da maior floresta tropical do mundo, Floresta Amazônica. É banhado ao norte e leste pelo Oceano Atlântico, limitada a oeste pelo meridiano de $47^{\circ} \mathrm{W}$ e ao sul pelo paralelo de $18^{\circ} \mathrm{S}$. Apesar desta localização, o NEB não apresenta uma distribuição de chuvas típicas das áreas equatoriais, mas inclui principalmente três tipos de climas com precipitação anual variando de 300 a 2.000 mm/ano: clima Litorâneo Úmido (do litoral da Bahia ao do Rio Grande do Norte); clima Tropical (em áreas dos Estados da Bahia, Ceará, Maranhão e Piauí); e clima Tropical Semi-árido, em todo o sertão nordestino (CEPLAB, 1978). 


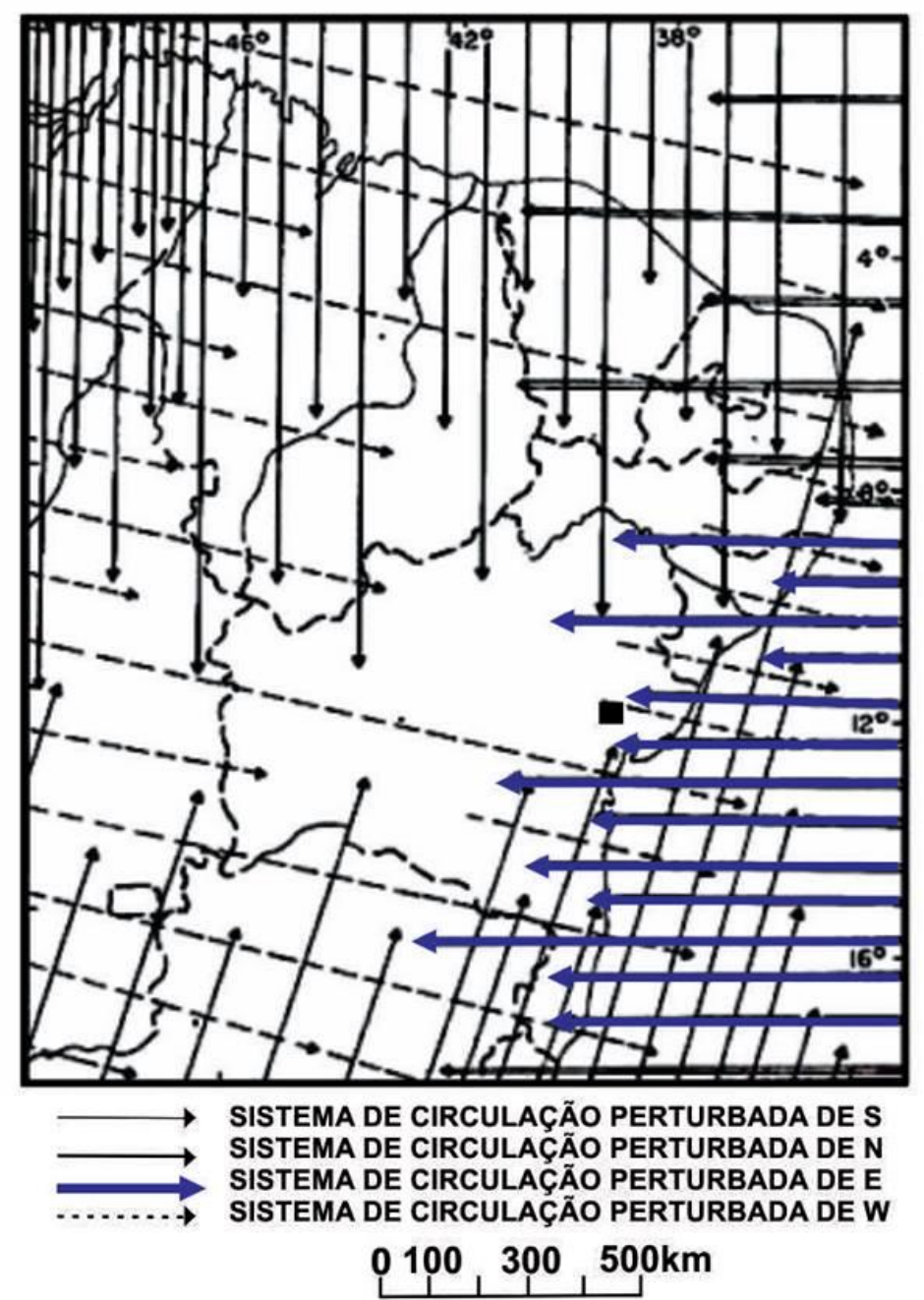

Microrregião de Feira de Santana

Figura 06: Sistemas de circulação atmosférica perturbadas da região Nordeste, destacando em azul a circulação perturbada de leste que atinge o estado da Bahia, especificamente a microrregião de Feira de Santana.

Fonte: Nimer (1977) adaptado por DINIZ (2016).

Segundo Nimer (1977) as correntes de circulação perturbadas são responsáveis pelas instabilidades e chuvas na região Nordeste, e compreendem quatros sistemas: correntes perturbadas de norte, sul, leste e oeste (Figura 06). A corrente perturbada de leste atinge o estado da Bahia, especificamente a microrregião de Feira de Santana, uma vez que, as ondas de leste caminham de leste para oeste, e são característicos dos litorais da 
zona tropical adentrando ao continente, na qual são atingidos pelos alísios e, consequentemente, chuvas mais ou menos abundantes anunciam sua passagem.

As precipitações devidas a este fenômeno diminuem bruscamente para oeste, adentrando ao continente, raramente ultrapassando as escarpas da Borborema e da Diamantina. Este sistema de circulação perturbada é mais frequente no inverno e secundário no outono, enquanto que na primavera e verão são menos frequentes.

A diversidade de climas no NEB deve-se à atuação de vários mecanismos físicos que interagem e são responsáveis pela distribuição de chuvas na região. Entre os principais fatores climáticos que determinam a distribuição dos elementos climáticos da NEB e sua variação sazonal, estão a posição geográfica, relevo, a natureza da superfície e os sistemas de pressão atuantes na região. O relevo nordestino é composto de dois extensos planaltos, Borborema e a bacia do rio Parnaíba, e de algumas áreas altas que formam as chapadas, como Diamantina e Araripe (CAVALCANTI, FERREIRA, SILVA e DIAS, 2009).

O NEB está sob a influência dos Anticiclones Subtropicais do Atlântico Sul (ASAS) e do Atlântico Norte (ASAN), e do cavado equatorial, cujas variações sazonais de intensidade e posicionamento determinam o clima na região. O ASAS intensifica-se com certa regularidade e avança sobre o país de leste para oeste, começando no final do verão do Hemisfério Sul, atingindo sua máxima intensidade em julho e declinando até janeiro. Por outro lado, o ASAN tem comportamento mais irregular: é forte em julho, enfraquece até novembro, 
intensifica-se até fevereiro, decresce até abril e intensifica-se novamente até julho.

Entre os Anticiclones Subtropicais do Atlântico Sul e do Atlântico Norte na faixa equatorial, está o cavado equatorial, sendo este influenciado pelos mesmos. Os ventos de baixos níveis associados aos sistemas de pressão são os alísios de sudeste, na borda norte do ASAS, e de nordeste, na borda sul do ASAN. No eixo do cavado equatorial está a Zona de Convergência Intertropical (ZCIT), cujas variações em posição e intensidade estão diretamente relacionadas às alterações nas posições e intensidades do ASAS e do ASAN. Assim, a ZCIT no Atlântico está na região de convergência dos alísios de nordeste e sudeste, apresentando movimentos ascendentes, baixas pressões, nebulosidade e chuvas abundantes, e segue as regiões onde a Temperatura da Superfície do Mar está mais elevada (CAVALCANTI et al., 2009).

A máxima precipitação no norte e no centro do NEB em março-abril deve-se à influência da ZCIT do Atlântico, está migra sazonalmente, em anos considerados normais, de sua posição mais ao norte (em torno de $14 \div-\mathrm{N}$ ), durante agosto-setembro para sua posição mais ao sul (em torno de $2^{\circ} S$ ), durante março-abril. A migração sazonal da ZCIT está atrelada aos fatores que causam fortalecimento ou enfraquecimento dos alísios de nordeste e sudeste, tendo papel importante na precipitação pluviométrica desta região.

Neste sentido, é válido ressaltar que a ZCIT é parte integrante da circulação geral da atmosfera, sendo definida como uma faixa de baixa pressão e convergência do escoamento nos baixos níveis da atmosfera, próximo à superfície. Proporciona condições favoráveis para movimento ascendente, gera, em consequência, condensação do vapor d'água, formação de nuvens e 
altas taxas de precipitação. Suas migrações sazonais para o norte e para o sul do equador, sobre o Atlântico Equatorial, bem como sua intensidade são fatores importantíssimos para a grande variabilidade das chuvas nas partes norte e central do Nordeste (GONÇALVES, 1992).

Em anos de seca a ZCIT, normalmente, não cruza o equador na sua migração sazonal para o sul, não atingindo, portanto, o Nordeste. Em anos chuvosos, desloca-se até $5^{\circ}-6^{\circ}$ sul, próximo à costa do Nordeste. Neste contexto, as pesquisas mais recentes têm revelado a estreita relação da ZCIT com a temperatura de superfície dos oceanos tropicais, uma vez que ela se situa, geralmente, sobre as áreas oceânicas de temperaturas mais elevadas. Constatou-se assim, uma relação entre padrão de anomalias da temperatura da superfície do mar com as anomalias de precipitação do Nordeste: águas mais aquecidas no Atlântico Sul Tropical e mais frias no Atlântico Norte Tropical estão associadas aos anos chuvosos, enquanto que, nos anos secos, o padrão fica essencialmente invertido (GONÇALVES, 1992).

Por conseguinte, um conjunto de variáveis meteorológicas que atuam sobre a faixa equatorial dos oceanos pode definir a ZCIT como a Zona de Confluência dos Alísios (ZCA), a região do cavado equatorial, as áreas de máxima Temperatura da Superfície do Mar (TSM) e de máxima convergência de massa, e a banda de máxima cobertura de nuvens convectivas. Essas variáveis atuam próximo à faixa equatorial dos oceanos e não se apresentam necessariamente sobre a mesma latitude em superfície, mas próximas umas das outras (CAVALCANTI et al., 2009).

A máxima precipitação de novembro a março, com um pico em dezembro no sul do NEB é ocasionada pela incursão de Sistemas Frontais 
(SFs) e seus remanescentes entre $5^{\circ}$ S e $18^{\circ} \mathrm{S}$ que interagem com a convecção local. Neste sentido, os SFs podem interagir com a convecção local, especialmente na primavera e no verão do hemisfério sul, quando os SFs apresentam ampla penetração continental, uma condição apontada como necessária para a interação (CAVALCANTI et al., 2009).

Kousky (1979) mostrou que os sistemas frontais ao adentrar em latitudes baixas também produzem um efeito pronunciado na atividade convectiva da faixa tropical. Estes sistemas constituem um importante mecanismo de produção de chuvas no Nordeste, uma vez que, são originários de altas e médias latitudes sul que entram no continente, e geralmente apresentam dois tipos de deslocamento: ou elas se deslocam para leste, trajetória que só modifica o tempo no sul do continente; ou elas se deslocam com uma componente para norte (Nordeste) e que, nesse caso, modificam o tempo em toda a região.

$\mathrm{Na}$ costa leste do NEB, escoamento médio e a brisa terra-mar ocasionam um máximo noturno ao longo da costa e um máximo diurno até 300 $\mathrm{km}$ distante da costa. Nesse setor, as máximas precipitações anuais (superiores a $1.500 \mathrm{~mm}$ ) concentram-se próximo a região litorânea, em consequência de influências de brisas que advectam nebulosidade, o que provoca a maior concentração de chuvas nessa área. Outra característica da precipitação do NEB é poder ser modulada por distúrbios de leste. Assim, para este setor do NEB, a máxima precipitação mensal de maio-julho foi justificada pela propagação de aglomerados de nuvens para oeste e pelos remanescentes de Sistema Frontal (SF) que se deslocam sobre a região e podem atingir latitudes equatoriais, principalmente no inverno do Hemisfério Sul o que pode 
ser facilitado pela componente meridional do escoamento típico de inverno (CAVALCANTI et al., 2009).

Kayano (2003) mostrou que, durante o inverno do Hemisfério Sul, as ondas de leste propagam-se no Atlântico Tropical Norte (ATN) com efeitos indiretos sobre o leste do NEB, e afetam principalmente a precipitação no norte da NEB, enquanto no verão do Hemisfério Sul a precipitação no NEB pode ser modulada pelo efeito combinado de incursão de ondas transientes e sinóticas de latitudes médias para latitudes equatoriais, ventos alísios e distúrbios de leste nas latitudes equatoriais.

A variabilidade pluviométrica é decorrência também de fenômenos como o El Niño-Oscilação Sul (ENOS), sendo este apontado como um dos principais fenômenos responsáveis pelas variações interanuais de precipitação pluviométrica, associado a anomalias de outros elementos meteorológicos da região do globo, relacionando aos sistemas dinâmicos da circulação atmosférica. As condições secas sobre o NEB em anos de ocorrência de El Niño são explicadas pela componente leste-oeste do ENOS, refletida em alterações de grande escala da circulação atmosférica associada a uma circulação de Walker deslocada para leste, com seu ramo ascendente sobre as águas anomalamente quentes do Pacífico Equatorial Leste, e ramo descendente sobre o Atlântico e o NEB (CAVALCANTI et al., 2009).

O fenômeno El Niño - Oscilação do Sul (ENOS) é constituído por dois componentes, um de natureza oceânica, El Niño, e outro de natureza atmosférica, Oscilação do Sul. A denominação El Niño foi utilizada pela primeira vez, no século XVIII, por pescadores peruanos, designando uma 
corrente de águas quentes que surgia no Oceano Pacífico, na costa da América do Sul em dezembro.

A expressão "O Menino", em espanhol El Niño, foi utilizada em alusão ao natal e ao Menino Jesus. O El Niño (fase quente) tem a característica de elevar acima da média a temperatura das águas da região oriental do Oceano Pacífico Tropical, juntamente com a ocorrência de pressões atmosféricas abaixo do normal na região do Taiti, e acima do normal na região de Darwin.

O estado da Bahia possui uma organização climática transicional e, ao mesmo tempo, ocupa uma posição geográfica de periferia em relação aos sistemas de circulação atmosférica atuantes no Nordeste brasileiro. No quadro regional, o estado é caracterizado pelas condições de tropicalidade, em decorrência de duas estações do ano bem marcadas: uma seca e outra chuvosa. Na maior parte do seu território as chuvas possuem grande variabilidade têmporo-espacial ao longo do ano. As áreas mais chuvosas são encontradas na faixa costeira, sobretudo, nas áreas compreendidas pelo Recôncavo Baiano e na Baía de llhéus, onde os volumes de chuvas anuais ultrapassam os $2.000 \mathrm{~mm}$.

Segundo Jesus (2008) a área central do estado da Bahia é formada por um grande conjunto morfo-estrutural (Espinhaço - Diamantina), que se dispõe no sentido norte- sul, onde são registradas as maiores cotas hipsométricas, constituindo-se em um mesoclima de alta potencialidade climática, decorrente de seus atributos (térmicos) de refúgio salubre de altitude. Apesar de estar inserido no semi-árido baiano, com áreas de piemontes bem contrastantes, nos setores oriental e ocidental, esta região apresenta uma paisagem singular no contexto do estado da Bahia, com um clima bem diferenciado. 
Grande parte da Chapada Diamantina é caracterizada pela existência de formas tabulares, dispostas em patamares estruturais, que se elevam entre 480 a 1.000 metros de altitude, aproximadamente. Se, por um lado, a acidez e a baixa fertilidade dos solos e os reduzidos índices pluviométricos impõem algumas restrições ecológicas ao uso agrícola, o relevo possibilita a existência de atributos climáticos de mesotermia e define atributos ímpares no contexto do estado, oferecendo amplo potencial para o turismo e o lazer.

A variabilidade espacial da pluviosidade no estado da Bahia pode ser caracterizada em áreas distintas, as quais são: a faixa do litoral, que possui índices superiores a 1100 mm, chegando até mesmo a 2000 mm em algumas áreas. Nesta região a chuva é caracterizada por ter uma distribuição mais regular no decorrer do ano. A parte ocidental do Estado, também possui índices elevados, com 800 mm, mas não apresenta uma distribuição regular da precipitação pluviométrica. A encosta Diamantina permite definir outra área com índices pluviométricos que atingem $800 \mathrm{~mm}$, assegurando um índice elevado o ano inteiro. Os índices pluviométricos mais baixos inferiores a 500 $\mathrm{mm}$ são encontrados nas áreas que constituem os setores semi-áridos do Estado abrangendo as regiões norte, nordeste e uma pequena porção no centro-sul (Figura 07).

SEPLANTEC (1978) deu suporte para a realização e publicou o Atlas Climatológico do estado da Bahia, documento síntese, na qual traz a análise de quatro grandes tipos climáticos para o estado da Bahia e cada tipo apresenta subtipos com características que os diferenciam entre si, com base nos índices climáticos, sendo os seguintes: Úmido, Úmido a Subúmido, Subúmido a Seco e Semi-Árido. Os tipos Úmido e Úmido a Subúmido distribuem-se na faixa 
litorânea, nos chapadões ocidentais e na vertente sul da Chapada Diamantina. A faixa litorânea apresenta-se como a área que detém o maior grau de umidade e os índices de chuva acima de $1.800 \mathrm{~mm}$ anuais, atingindo valores em torno de $2.000 \mathrm{~mm}$ no litoral. Por outro lado, à medida que se aproxima da Serra Geral de Goiás, que divide as águas da Bacia do São Francisco e de Tocantins, contrasta com a faixa litorânea no que diz respeito à concentração de chuvas, pois, embora a precipitação ocorra em todos os meses do ano, a faixa oeste exibe uma estação seca bem definida no inverno. Isto se deve aos sistemas de circulação atmosférica atuantes na faixa oeste como o sistema de circulação perturbada de oeste fazendo com que as precipitações não sejam distribuídas de forma equitativa ao longo do ano. Seu regime sazonal é tipicamente tropical, com acentuada máxima no verão e mínima no inverno. Mais de $70 \%$ do total de chuvas acumuladas durante o ano se precipitam normalmente de novembro a março, sendo mais chuvoso o trimestre janeiro, fevereiro e março.

O tipo climático da microrregião de Feira de Santana em função da sua posição geográfica no cenário baiano é o clima tropical Subúmido alternando para o Seco, segundo a classificação proposta por Thornthwaite e Matther (1955). Neste município, as condições climáticas são regidas por diferentes sistemas de circulação atmosférica ao longo do ano (de natureza oceânica e continental), registrando-se precipitação pluviométrica média de $848 \mathrm{~mm}$ anuais e temperatura média anual de $24^{\circ} \mathrm{C}$, podendo, no verão, atingir máximas de $27^{\circ} \mathrm{C}$ e no inverno mínimas de $22^{\circ} \mathrm{C}$. 


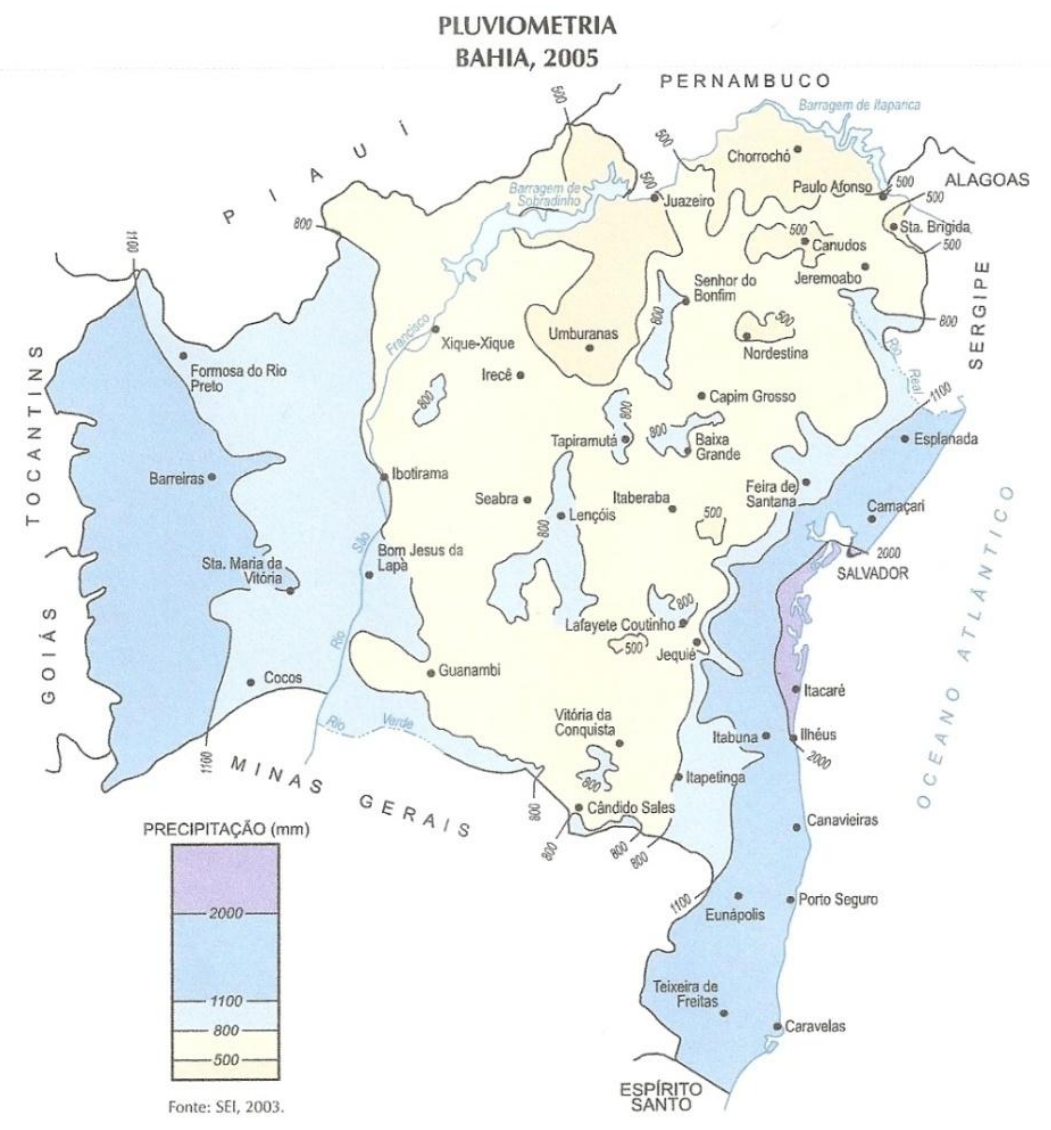

Escala: 1:2.000.000

Figura 07: Mapa de Pluviometria do estado da Bahia. Fonte: SEI (2005)

A área de estudo tem a atuação de alguns sistemas de circulação atmosférica como os Sistemas Frontais que são originários das altas e médias latitudes do hemisfério sul, como descontinuidades resultantes do contato entre os anticiclones polar e subtropical que atuam no Nordeste, durante o ano todo, até a latitude de $13^{\circ} \mathrm{S}$, neste sentido, a microrregião em estudo recebe a influência dos Sistemas Frontais na precipitação pluviométrica. Como afirmado por Gonçalves (1992) a concentração das chuvas no outono-inverno é uma decorrência da atuação mais efetiva dos SFs que, mas vigorosos nesta época, 
atingem mais facilmente esta latitude. Ao longo dos anos o outono se apresentou mais chuvoso na área de estudo, principalmente no mês de maio.

Além disso, Kousky (1980) chama a atenção para a importância da circulação típica das áreas litorâneas do norte/nordeste da América do Sul - ou seja, os mecanismos de brisas marítimas e terrestres - influenciando nas chuvas. Suas observações enfatizam que a atividade decorrente do desenvolvimento de uma linha de cumulunimbus associada à brisa marítima, nestas áreas, é responsável por uma quantidade apreciável de precipitação, podendo se propagar como uma linha de instabilidade em direção ao interior do continente. Como dito por Cavalcanti (2009) e já apresentado o escoamento médio e a brisa terra-mar ocasionam um máximo noturno ao longo da costa e um máximo diurno até $300 \mathrm{~km}$ distante da costa.

Como já discutido anteriormente, a microrregião de Feira de Santana recebe influência da corrente perturbada de leste, uma vez que, são característicos dos litorais da zona tropical adentrando ao continente, na qual são atingidos pelos alísios e caminham de leste para oeste, além disso, tais fenômenos de perturbação ocorrem no seio dos anticiclones tropicais, sobre o continente e, também, com a penetração de frentes frias em baixas latitudes.

Por outro lado com relação à variabilidade pluviométrica da microrregião de Feira de Santana, o fenômeno El Niño-Oscilação Sul (ENOS) traz períodos secos e são explicadas pela componente leste-oeste do ENOS, refletida em alterações de grande escala da circulação atmosférica associada a uma circulação de Walker deslocada para leste, com seu ramo ascendente sobre as águas anomalamente quentes do Pacífico Equatorial Leste, e ramo descendente sobre o Atlântico e o NEB como dito por Cavalcanti (2009). 


\subsection{CARACTERIZAÇÃO DA CULTURA DO MILHO}

O milho (Zea mays L.) há alguns séculos vem sendo utilizado diretamente na alimentação humana e de animais e a sua importância não se restringe apenas ao fato do seu grande volume mundialmente produzido, mas também ao importante papel socioeconômico que representa. Constitui ainda em fonte de matéria-prima para uma expressiva série de produtos industrializados, tais como amido, óleo, flocos, fubá, farinha, dentre outros. Segundo alguns pesquisadores o milho é originário do continente americano, oriundo do México e dos Estados Unidos.

Este cereal sofreu intensa evolução em quase todas as civilizações que o cultivaram, principalmente os Astecas, Mais e Incas e, como consequência desta alta domesticação, seleção natural e hibridização o milho é uma espécie altamente polimórfica, com alta variabilidade genética, sendo conhecidas atualmente com mais de 250 raças e mais de 2500 variedades de milho.

Os indígenas brasileiros, muito antes dos navegadores portugueses, já utilizavam o milho, na qual figurava como um dos alimentos mais importantes ao lado da mandioca. Os indígenas utilizavam o referido cereal, sob a forma de farinha. Ainda no Brasil, documentos históricos de 1834 relatam a importância do milho como fonte alimentar, constituindo-se na época um dos principais objetos de especulação dos cultivadores dos estados de Minas Gerais e Goiás.

O milho no Brasil foi cultivado para atender as necessidades internas ou, mais especificamente das propriedades rurais, é importante ressaltar que 0 milho ocupa no país a maior extensão de área plantada entre todos os produtos agrícolas. Com base no Ministério da Agricultura (2012) estima-se 
que $10 \%$ da produção do milho se destinem ao consumo humano. Cerca de 50 a $60 \%$ é empregada na formulação de rações, e o restante 30 a $40 \%$ é fornecida diretamente aos animais.

O milho exige durante o seu ciclo vegetativo, calor e umidade para se desenvolver e produzir satisfatoriamente. Esta cultura exige no mínimo de 200 $\mathrm{mm}$ de precipitação pluviométrica no verão, para que produza sem a necessidade da prática de irrigação. Assim, as localidades cujas precipitações pluviométricas anuais oscilem entre 250 a 5000 mm são consideradas aptas para o plantio do mencionado cereal. Quanto à temperatura anual, esta deve variar entre 25 e $30^{\circ} \mathrm{C}$, propiciando as melhores condições para a germinação das sementes.

A importância econômica do milho é caracterizada pelas diversas formas de sua utilização, que se estende desde a agricultura familiar até a indústria de alta tecnologia. É uma cultura temporária e bastante importante na produção na alimentação animal representa a maior parte do consumo deste cereal, isto é, cerca de $70 \%$ no mundo, principalmente na forma de rações, onde aparece como componente principal, devido o seu alto valor energético.

A cultura do milho se desenvolve em solos profundos, bem drenados e com boa fertilidade, cujo índice $\mathrm{pH}$ esteja compreendido entre 5,5 e 7,5. $\mathrm{O}$ sistema radicular atinge aproximadamente profundidades de até $1,5 \mathrm{~m}$. Enquanto o porte do milho é pequeno, as suas raízes se desenvolvem quase que paralelamente à superfície do solo, penetrando verticalmente até a profundidade de $30 \mathrm{~cm}$ no máximo. O sistema radicular da planta é bastante ramificado, fazendo com que a cultura tolere bem os períodos de escassez de chuvas. 
O milho pertence ao grupo de plantas com metabolismo fotossintético do tipo C4, que se caracteriza pelo elevado potencial produtivo. Entre as plantas C4, o milho está no grupo de espécies com maior eficiência de uso da radiação solar ou eficiência quântica, com valor médio entre 64,5 a $69 \mathrm{mmol}^{\mathrm{mol}}{ }^{-1}$, enquanto outras espécies C4 apresentam valores em torno de 52,6 a 60,4 $\mathrm{mmol} \mathrm{mol}{ }^{-1}$. Esta maior eficiência é atribuída à anatomia foliar, por apresentar menor área entre as nervuras e lamela suberizada, o que previne a perda de CO² para o meio (HATTERSLEY, 1984).

A cultura do milho apresenta o período crítico, que vai da pré-floração ao início do enchimento de grãos. Nessa etapa fenológica, o milho é sensível ao déficit hídrico, podendo-se observar esta sensibilidade nos processos fisiológicos ligados à formação do zigoto e início do enchimento de grãos, e na elevada transpiração que ocorre nesse período, em razão do maior índice de área foliar. Os eventos de formação do zigoto e início do crescimento dos grãos são muito suscetíveis a estresses, sobretudo ao déficit hídrico (SCHUSSLER e WESTGATE, 1991).

A absorção, o transporte e a consequente transpiração de água pelas plantas são consequência da demanda evaporativa da atmosfera (evapotranspiração potencial), resistência estomática e difusão de vapor, água disponível no solo e densidade de raízes. A planta absorve água do solo para atender às suas necessidades fisiológicas e, com isto, suprir a sua necessidade em nutrientes, que são transportados junto com a água, sob a forma de fluxo de massa. Do total de água absorvida pela planta, uma quantidade bem reduzida (cerca de $1 \%$ ) é retida pela mesma. 
O milho é uma das mais eficientes plantas armazenadoras de energia existentes na natureza. De uma semente que pesa pouco mais de $0,3 \mathrm{~g}$ irá surgir uma planta geralmente com mais de 2,0 m de altura, isto dentro de um espaço de tempo de cerca de nove semanas. Nos meses seguintes, essa planta produz cerca de 600 a 1.000 sementes similares àquela da qual se originou.

O caráter monóico e a sua morfologia característica resultam da supressão, condensação e multiplicação de várias partes da anatomia básica das gramíneas. Os aspectos vegetativos e reprodutivos da planta de milho podem ser modificados através da interação com os fatores ambientais que afetam o controle da ontogenia do desenvolvimento. Contudo, o resultado geral da seleção natural e da domesticação foi produzir uma planta anual, robusta e ereta, com um a quatro metros de altura, que é esplendidamente "construída" para a produção de grãos.

O milho é uma planta monocotiledônea ${ }^{1}$ e pertence à família das gramíneas do gênero Zea, sendo cientificamente designada pela espécie Zea mays $L$. Morfologicamente a planta apresenta ciclo variável entre 110 a 180 dias, compreendendo as seguintes etapas (Figura 08):

a. Germinação ou estabelecimento: período compreendido desde a semeadura até o efetivo aparecimento da plântula, em função do solo pode oscilar entre 15 a 25 dias de duração;

\footnotetext{
1 As monocotiledôneas são um grupo de plantas angiospérmicas (angiospermas ou magnoliófitas) que se caracteriza taxonomicamente na botânica como categoria de planta cujo embrião tem, tipicamente, um só cotilédone, raiz fasciculada (raízes ramificadas) e folhas paralelinérveas.
} 
b. Período vegetativo: período compreendido desde a emissão da segunda folha até o início do florescimento compreende 25 a 40 dias;

c. Florescimento: período compreendido entre o início da polinização e o início da frutificação, cuja duração é entre 15 a 20 dias;

d. Frutificação: período compreendido entre o início do enchimento dos grãos até o início da maturação compreende 35-45 dias;

e. Maturação: período compreendido entre a maturação fisiológica e o momento de colheita compreende 10-15 dias.

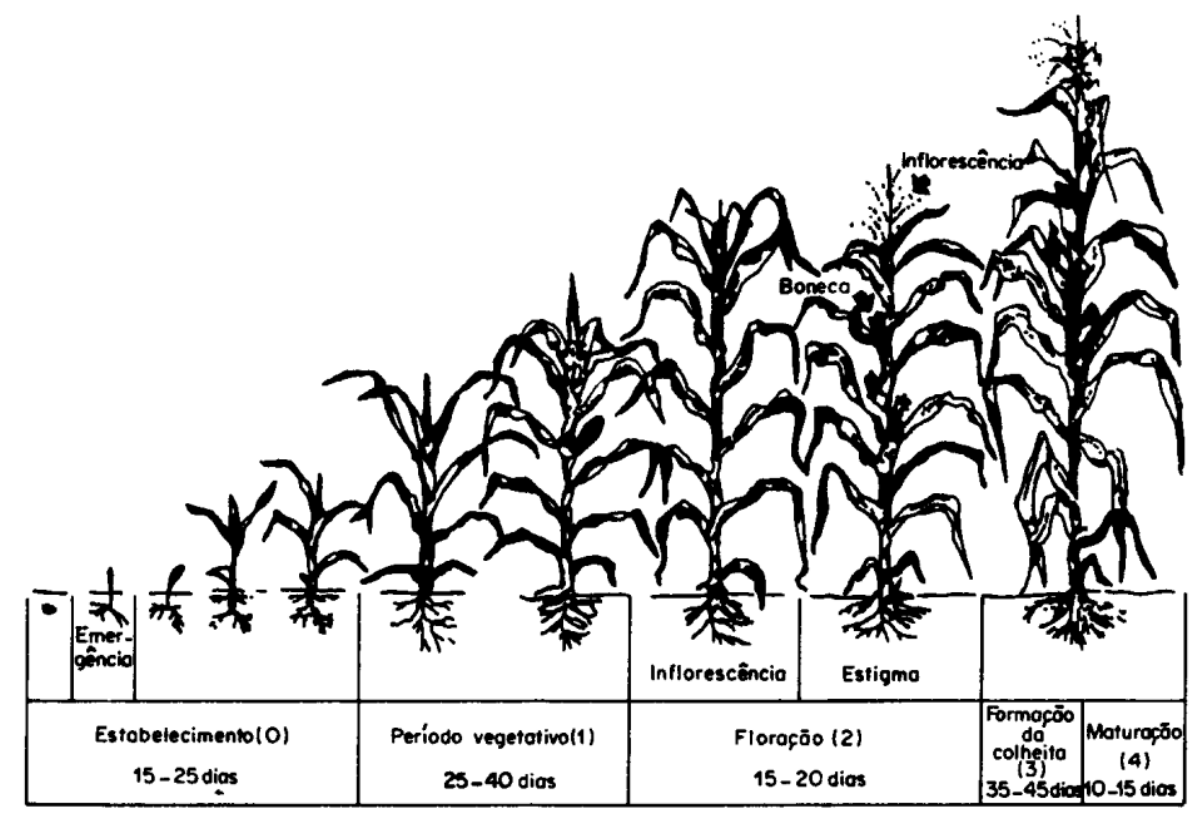

Figura 08: Fases de desenvolvimento da cultura do milho.

Fonte: MAIA (2003) 


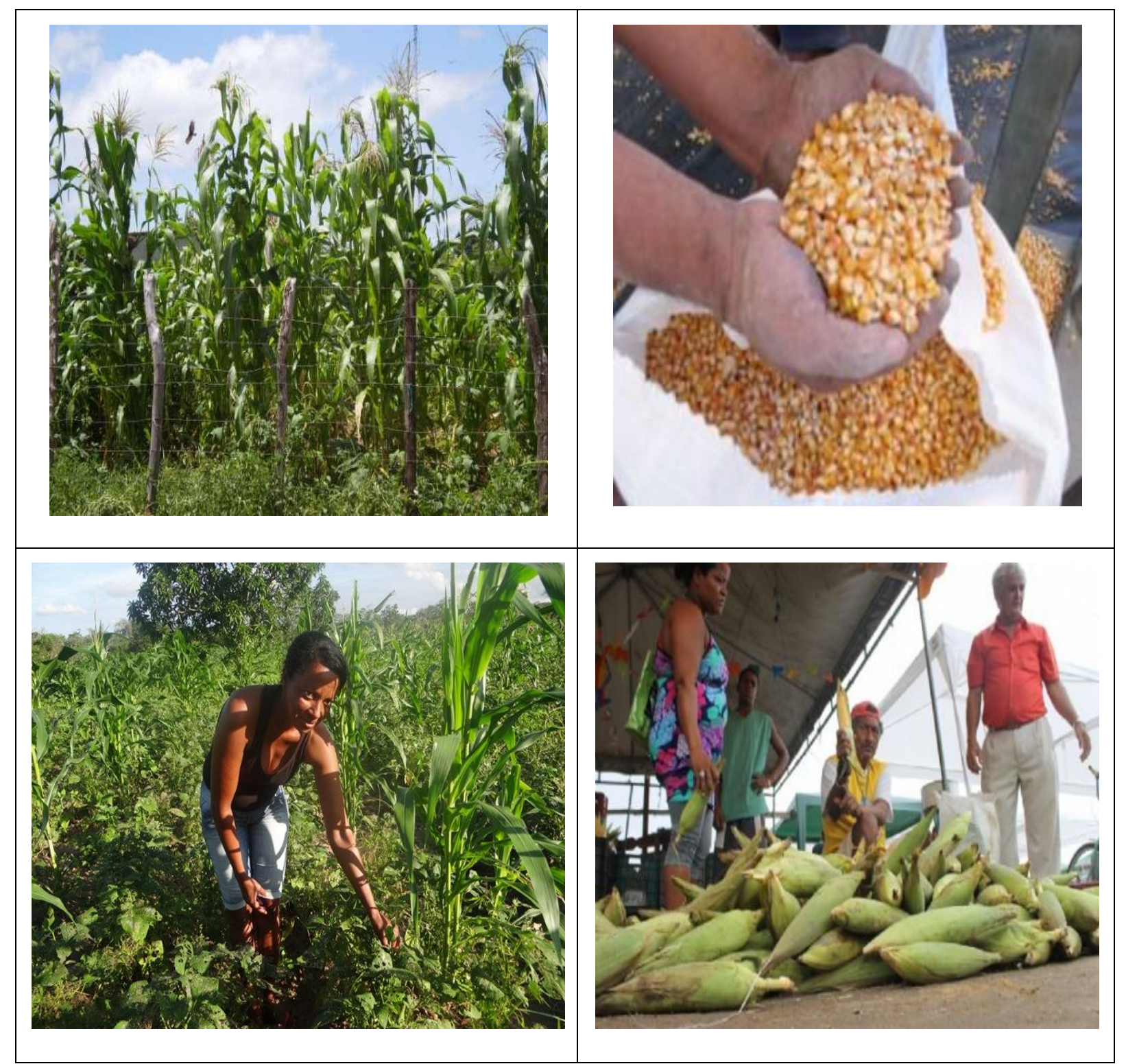

Figuras 09 a 12: Cultura do milho na microrregião de Feira de Santana.

Fonte: DINIZ (2014)

O sistema radicular apresenta dois tipos de raízes: primárias e adventícias; o caule é cilíndrico tipo colmo com nós e entrenós; e as folhas são do tipo lanceolado, possuem limbo e são alternadas. As inflorescências são duas: masculina e feminina, sendo que na masculina, o pendão é constituído de eixo central com ramificações e espiguetas, onde estão as flores. Cada panícula (pendão) pode produzir de dois a cinco milhões de grãos de pólen. A feminina (boneca) quando bem desenvolvida pode reunir de setecentas a mil 
flores, e a semente, por sua vez, é do tipo cariopse que é um fruto seco de semente única.

A espiga corresponde em estrutura a um colmo, as bainhas foliares (palhas) originam-se de cada nós que são fortemente superpostas e firmemente envolvidas em torno da espiga, evitando a dispersão natural. Os pares de espiguetas de cada espiga diferem da do pendão, e as glumas envolvem parcialmente a espigueta. (GOODMAN apud PATERNIANI, 1987). 


\section{REFERENCIAL TEÓRICO-CONCEITUAL}

A Teoria Geral dos Sistemas (Bertalanffy, 1973) foi fundamental para o entendimento do papel dos atributos do clima nos processos e estruturas espaço-temporais, tanto em ambientes naturais quanto antrópicos. A adoção do paradigma sistêmico na análise físico-geográfica, além de permitir valiosa contribuição metodológica, torna a análise de elementos atuantes no sistema (geossistema) inexoravelmente interativos. Neste sentido, é importante a abordagem sistêmica na reveleção dos diferentes atributos naturais e antrópicos. Por estes aspectos o clima assume importante papel como insumo na agricultura, considerado como regulador dos processos agrários como afirma Monteiro (1976), além disso, o clima apresenta diferentes maneiras de influenciar o espaço geográfico.

Os conceitos que nortearam o desenvolvimento desta pesquisa foram de variabilidade pluviométrica e produtividade agrícola. Além disso, foram utilizadas as categorias de análise como circulação atmosférica, pluviosidade e tipologia climática. Para tanto, foram consultados diversos trabalhos como obras específicas, a fim de embasar o processo de construção do referencial teórico-conceitual.

\subsection{VARIABILIDADE PLUVIOMÉTRICA}

Morize (1889) realizou um estudo sobre um Esboço da Climatologia do Brasil retratando as relações do clima com os aspectos humanos; realizou uma proposta de classificação climática que concebia como ponto de partida os 
conceitos adotados por Köppen, no que se refere às médias térmicas, sazonalidade e totais pluviométricos. Utilizando 106 estações meteorológicas, o autor se apoiava nos climogramas para determinar os tipos climáticos; além de um expressivo conjunto de dados meteorológicos.

Carvalho (1917) tratou os aspectos climáticos do Brasil, apontando as concepções gerais sobre o tempo e o clima. Este autor estruturou sua obra em três partes: a primeira tratava dos elementos e fatores climáticos, especificamente no hemisfério sul; a segunda, da variabilidade, sazonalidade e distribuição dos fatores meteorológicos; e a terceira, que chamou de climatologia, propunha uma classificação dos climas do Brasil.

Ferraz (1925) realizou um trabalho sobre as causas prováveis das secas do Nordeste brasileiro retratando as secas nordestinas, procurando averiguar quais os agentes atmosféricos mais diretamente responsáveis pelo fenômeno das intensas estiagens, empregou seus ensaios a partir da análise das cartas sinóticas para explicar as causas prováveis das secas do Nordeste brasileiro. Analisou, também, o papel do anticiclone polar atlântico e definiu-o como o responsável pelo fenômeno da friagem amazônica.

Setzer (1946) fez um estudo sobre a distribuição normal das chuvas no Estado de São Paulo, para explicar diversas questões pedológicas, diretamente inter-relacionado com o clima. $\mathrm{O}$ autor calculou as normais mensais, sazonais e anuais da pluviosidade no espaço paulista para 246 localidades, com uma média de 18 anos para o período de registro, que terminava no primeiro semestre de 1945. Setzer elaborou com base neste material, sete mapas, sendo o primeiro a distribuição das médias pluviométricas do Estado, e no restante dos mapas caracterizou a pluviometria 
das estações do ano, sendo os dois últimos mapas correspondentes aos meses mais secos e chuvosos. O autor concluiu que, na primeira metade do século $\mathrm{XX}$, a estiagem, se tornou mais aguda e prolongada no espaço paulista, e a estação chuvosa se tornou mais curta e intensa, evolução esta que, segundo o autor, reflete os sinais de uma evolução climática ocasionados principalmente pelo desmatamento da vegetação paulista.

Monteiro (1976) desenvolveu um estudo sobre a relevância do clima na organização econômica do espaço geográfico do Estado de São Paulo, através espacialização dos fenômenos climáticos; o clima e a organização econômica; o clima e a sua relação com a qualidade do ambiente. Além disso, ressaltou também algumas questões metodológicas sobre a variabilidade climática espacial e temporal.

Monteiro (1981) realizou um trabalho sobre os fatores climáticos na organização da agricultura nos países tropicais em desenvolvimento: conjecturas sobre o caso brasileiro, o autor retomou a discussão do papel das variáveis climáticas nos processos de organização agrícola, em especial o problema da aplicabilidade das mesmas nos países tropicais em esforços de desenvolvimento. Este trabalho focalizou a relação entre o binômio clima e agricultura que acaba repercutindo ou refletindo conexões importantes nos outros domínios geográficos, além disto, ressaltou algumas inferências sobre o papel dos fatores climáticos na agricultura e o papel da pesquisa climatológica no esforço geral de desenvolvimento.

Mota (1983) realizou um estudo sobre a meteorologia agrícola e acrescentou que a agricultura é dependente dos seguintes recursos naturais: clima, topografia, solo, vegetação, animais, água, homem, depósitos minerais e 
combustíveis. O clima, por sua vez, varia no tempo e no espaço, e os componentes mais importantes são precipitação e radiação solar. Além disso, aborda que o clima assume significância em quase todas as fases das atividades agrícolas desde a seleção de lugares para a instalação de culturas e experimentos agrícolas, até o planejamento a longos ou curtos prazos. Desta forma, é perceptível que o clima é muito importante na agricultura, desde a escolha da área para sua instalação, até o planejamento a longo ou curto prazos, através do monitoramento de períodos excepcionais, que possam repercutir de forma negativa nas lavouras.

Mota (1986) retratou em seu trabalho sobre clima e agricultura no Brasil, a seca como o maior flagelo meteorológico da agricultura brasileira. Além disso, este autor abordou uma previsão agrometeorológica para o rendimento de cereais, através da construção de modelos que levam em consideração o clima-rendimento, estabelecendo um banco de dados históricos meteorológicos e de rendimentos das culturas. Além disso, mencionou um estudo sobre as condições climáticas e o desenvolvimento do trigo, visando estabelecer uma relação entre clima, adaptação, rendimento e zoneamento do trigo no Brasil.

Nimer (1989) realizou um trabalho sobre a climatologia do Brasil e explanou a climatologia da região Nordeste, na qual se caracteriza pelo regime anual de chuvas com secas prolongadas, devido principalmente a irregularidade na sua distribuição. Diante disto, acrescentou que nenhuma outra região brasileira acusa desvios tão significativos como o Nordeste, quase todo o território desta Região apresenta desvio médio (positivo ou negativo) em relação à normal, superior a $25 \%$, e são bem maiores na área do polígono das 
secas. Em algumas áreas deste setor o desvio médio chega a alcançar índices superiores a $50 \%$, o que significa um dos mais expressivos do mundo.

Monteiro (1991) realizou um estudo sobre clima e excepcionalismo: conjecturas sobre o desempenho da atmosfera como fenômeno geográfico. Este autor argumentou que a ciência geográfica visa integrar as diferentes esferas terrestres para uma compreensão da organização e transformação dos espaços, sob um prisma antropocêntrico, e tem no estudo dos climas, um dos mais variados tópicos de seu objeto e estudo. Este autor focalizou a importância dos estudos do clima na Geografia, pois o este apresenta um papel primordial como regulador da produção agrícola.

Ribeiro (1993) tratou sobre a climatologia geográfica e a organização do espaço agrário e acrescentou que o clima é um fator essencial no processo de organização espacial da sociedade, sobretudo na organização do espaço agrário, quando os atributos climáticos exercem um condicionante no processo produtivo. Esse processo produtivo agrário, muitas vezes, está direcionado aos cultivos agrícolas comerciais, os quais devem estar sempre associados a um clima ideal para o desenvolvimento biológico da planta. Estas adaptações dos cultivos agrícolas comerciais contam com o apoio dos modelos numéricos que calculam o balanço hídrico existente entre planta-solo-atmosfera.

Christofoletti (1993) realizou um estudo sobre as implicações geográficas relacionadas com as mudanças climáticas globais, preocupando-se inicialmente em conceituar expressões que estão ligadas às mudanças climáticas globais, tais como: variabilidade, oscilação e tendência; designando, caracterizando e diferenciando tanto no tempo como no espaço as definições abordadas. As mudanças climáticas globais afetam diretamente o fluxo de 
matéria e energia do sistema, delineando um novo comportamento das implicações geográficas, que são divididas pelo autor em diversas categorias, sendo elas: as baixadas litorâneas; química da atmosfera, circulação atmosférica e condições climáticas, modificações no geossistema; distribuição espacial da agricultura e as reações geomorfológicas.

Nunes e Lombardo (1995) abordaram em um trabalho a questão da variabilidade climática através da consideração de diversos artigos que são voltados a essa temática. Acrescentaram que embora a variabilidade seja uma componente conhecida dentro da dinâmica climática, seu impacto, mesmo dentro de limites esperados, pode ter reflexos significativos nas mais diversas atividades humanas, principalmente a agricultura. Este trabalho apresentou uma discussão quanto às formas de tratamento dados à temática, apresentando alguns resultados parciais.

Santos (1996), em seu trabalho sobre as mudanças climáticas no Estado de São Paulo, procurou demonstrar que o homem vem causando enormes alterações no sistema ambiental, acentuadas, recentemente, pelas emissões de gases estufa que resultam no aumento das chuvas. A referida autora, através da tendência e da variabilidade das chuvas no Estado de São Paulo, utilizando dados de 22 postos pluviométricos de uma série de 52 anos (19411993), analisou as alterações climáticas a de curto prazo, com base nos dados pluviométricos, procurando verificar a existência e as características das inconstâncias climáticas nos postos localizados nas nove tipologias climáticas localizadas no espaço paulista. Concluiu que houve redução das chuvas em três unidades climáticas: Litoral e Planalto Atlântico Norte (Ubatuba), Vale do Paraíba (Paraibuna) e Mantiqueira (Campos de Jordão). Em equilíbrio, a 
porção Central do Litoral Paulista (Iguape), e o aumento das chuvas em todo o restante do Estado.

Aragão (2000) realizou um trabalho sobre a previsão da precipitação no norte do Nordeste do Brasil para o período chuvoso de fevereiro a maio: nos anos 1997/98, nesse estudo, foram abordadas as anomalias na precipitação total observadas de fevereiro a maio no norte semiárido do Nordeste do Brasil com indicações de grupos: anos secos, normais e chuvosos. Os anos de 1997 e 1998 apresentaram-se como anos secos, como base em 67 estações meteorológicas. Além disso, o ano de 1997 apresentou uma redução na quantidade de chuva entre 30 a 50\%, o déficit hídrico foi intensificado em 1998 com grandes impactos na agricultura e pecuária. Por conseguinte, ainda tratou que o veranico, conhecido como a ausência de chuvas de uma semana até um mês, quando acontece em determinadas fases do cultivo vegetal, ocorre à conhecida seca verde, como por exemplo, na cultura do milho, em que as folhas ficam verdes e a espigas não desenvolvem o grão.

Sant'anna Neto (2002) realizou um estudo sobre a análise da variabilidade das chuvas no Extremo Oeste Paulista (1971/1999), e apontou que a questão da variabilidade climática e das mudanças climáticas tem sido um dos temas de maior relevância nas discussões atuais sobre os destinos da humanidade. Na literatura científica recente, tem sido demonstrado que os regimes climáticos têm sofrido anomalias, muitas delas com graves consequências socioambientais. Sob esse aspecto, no clima tropical, as chuvas têm se revelado como o elemento de maior irregularidade, tanto espacial, quanto temporal, o que significa enormes repercussões nas atividades socioeconômicas. No caso do estado de São Paulo e, mais 
especificamente em sua porção oeste, tem se verificado dois aspectos que afetam profundamente esta que é uma região eminentemente agropecuária: a concentração pluvial, com episódios de chuvas muito intensas; e o aumento do período de estiagem no inverno e primavera.

Grimm apud Cavalcanti et al (2009) desenvolveu um trabalho sobre a variabilidade interanual do clima do Brasil, e argumentou que esta variabilidade apresenta significativa contribuição para a variância da precipitação em várias regiões, principalmente porque a precipitação é o mais importante parâmetro climático. Alguns resultados observacionais levaram Moura e Shukla apud Cavalcanti et al (2009) a propor um mecanismo dinâmico para explicar as secas do NEB, e os autores utilizando modelos numérico e teóricos, além de análises diagnósticas, propuseram que as secas no NEB podem ser explicadas pela ocorrência simultânea de uma fonte de calor ao norte do equador e um sumidouro ao sul, que induzem uma circulação termicamente forçada, a qual produz movimentos ascendentes ao norte do equador e descendentes ao sul, inclusive sobre o NEB.

\subsection{CLIMA E A PRODUTIVIDADE DA CULTURA DO MILHO (Zea mays L.)}

Carvalho (1967) realizou um estudo sobre os aspectos geoeconômicos da produção do milho, argumentou inicialmente sobre a importância deste cultivo, devido a sua multiplicidade de usos. A sua classificação botânica e suas formas genéticas são mostradas pelo autor que abordou mais de seis formas genéticas cultivadas no mundo. Mais adiante abordou uma descrição 
minuciosa desde o sistema radicular até as características dos grãos de milho (cor e forma). Além disso, tratou o perfil geoeconômico do Brasil sobre a produção do milho, que se desenvolvem sob duas formas básicas: a familiar e a produção em larga escala, sendo esta última produzida principalmente nas regiões Sudeste e Sul do Brasil. Segundo o IBGE (2009) o Nordeste detém a metade dos estabelecimentos de agricultura familiar do país (2.187.295) e $35,3 \%$ da área total deles ( 28,3 milhões de hectares). Na referida região, estes representam $89 \%$ do total de estabelecimentos e 37\% da área. Cinco dos dez maiores estados brasileiros em termos de número de estabelecimentos de agricultura familiar são nordestinos, com destaque para Bahia, em primeiro lugar, com 665.831 (ou 15,2\% do total nacional) e o Ceará, em quarto (341.510 ou $7,8 \%$ do total).

Une (1979) publicou um trabalho sobre os fatores climáticos influenciando a agricultura em Campo Grande (MT), abordou a relação entre chuvas e produção agrícola nos meses de dezembro, janeiro e fevereiro, considerando-os não significativos. Em março, quando o milho se encontra em fase de secagem natural para ser colhido, a partir de abril, ele passa a não necessitar de chuva e assim a pequena oferta hídrica de Campo Grande, como também a redução gradativa do número de dias de chuva, vem facilitar a colheita nos meses subsequentes, e em consequência, a produção do milho apresenta alta correlação positiva com as chuvas de março. Ao analisar os níveis de produtividade do Nordeste, observou-se que ela é historicamente muito baixa, sendo inferior a $1.000 \mathrm{~kg} / \mathrm{ha}$ até o início dos anos 2000 . A partir do início desta década, os níveis de produtividade aumentaram até alcançar a média de $1.300 \mathrm{~kg} / \mathrm{ha}$ nos últimos anos; isto principalmente pelo aumento da 
produção de milho nas regiões Oeste da Bahia, Alto do Rio Parnaíba no Piauí e Sul do Maranhão.

Fancelli e Lima (1982) realizaram um estudo sobre produção, préprocessamento e transformação agroindustrial do milho a partir de uma analise histórica com a origem e difusão do milho; sua importância econômica em âmbito mundial e nacional; e, os problemas da cultura. Além disso, argumentaram sobre as características botânicas, grupos genéticos e o ciclo vegetativo e fisiológico. Este trabalho retratou a relação entre clima e solo, e os autores destacaram que as deficiências hídricas podem afetar sensivelmente 0 processo germinativo, comprometendo o estabelecimento da cultura, deficiências posteriores podem paralisar o crescimento, bem como retardar o desenvolvimento reprodutivo das plantas.

Coelho (1988) realizou um estudo sobre a estimativa da estabilidade de produção em cultivares de milho para o estado de Minas Gerais, foi estudada a estabilidade da produtividade de grãos de 28 híbridos de linhagens, quatro híbridos intervarietais e quatro variedades de milho (Zea mays L.), em doze regiões do Estado de Minas Gerais. As cultivares Cargill 115, Dekalb 678, Cargill 525, Germinal 15C, Cargill 111 S, e Cargill 511 A, apresentaram boa produtividade. De acordo com o parâmetro de estabilidade, as cultivares Germinal 491, Germinal 493, CMS 12, Cargill 203, Pioneer 3218, Pioneer 3216 , Pioneer 6875 e Agroceres 352 F, apresentaram alta estabilidade. As cultivares Germinal 493, Cargill 511 A, Pioneer 3216 e Agroceres 302 apresentaram os menores valores para os desvios da regressão $\left(S^{2} d\right)$. As cultivares Cargill 511 A, Pioneer XCH 36 e Agroceres 303 apresentaram ampla estabilidade de produção de acordo com os parâmetros de estabilidade estudados. As 
variedades de polinização aberta CPJ VI e CMS 12, CMS 06 e IAC Maya XXI foram mais e menos estáveis na resposta ao ambiente, respectivamente.

Tubelis (1988) desenvolveu um estudo sobre a chuva e a produção agrícola, ressaltou que a produção agrícola é substancialmente afetada pelas condições atmosféricas. Esta influência se faz sentir nas fases de plantio, crescimento, frutificação e colheita dos produtos agrícolas. Além disso, argumentou que a precipitação pluviométrica é muito útil na propriedade agrícola, pois resulta em boas colheitas, já a escassez e/ou inadequada distribuição prejudicam o desenvolvimento e a produção dos cultivos, pois a produtividade das culturas está relacionada com a precipitação pluvial. Desta forma, podemos perceber que o conhecimento das chuvas se torna bastante importante no espaço agrário, pois permite estimar com antecedência a produtividade das culturas. No campo da meteorologia este autor ainda destacou questões relevantes sobre o cultivo do milho, como as suas características, a citar a relação entre o milho e a intensidade luminosa, revelando que as maiores produções da cultura são obtidas nos locais de maior disponibilidade de radiação solar.

Burman e Navarro (1992) realizaram um trabalho sobre estimativas das safras agrícolas no Estado da Bahia e elaboraram duas séries de dados de produção agrícola do referido Estado, tendo como fonte IBGE (Censo Agropecuário e a Pesquisa da Agropecuária Municipal), e encontraram diferenças significativas quando analisadas estatisticamente, considerando dados relativos à produção das 20 principais culturas, além de aplicar o teste entre as médias. As divergências estatísticas encontradas na produção agrícola, publicadas pela mesma fonte, desorientam as tomadas de decisões. 
Carvalho (1992) publicou um trabalho sobre a produção de milho na Bahia e ressaltou que em 1989 a produção baiana de milho no contexto mundial era de apenas $1 \%$. Além disso, enquanto nos outros estados da região Nordeste mantiveram-se a produtividade agrícola em torno de $640 \mathrm{~kg} / \mathrm{ha}$, o estado da Bahia apresentou rendimento médio de milho de $496 \mathrm{~kg} / \mathrm{ha}$, inferior a média dos outros estados do Nordeste. O autor justifica as causas da baixa produtividade agrícola: a) distribuição irregular das chuvas durante o ciclo de cultivo; b) baixa fertilidade dos solos; c) baixa capacidade produtiva das variedades utilizadas pelos produtores; d) uso de sementes de má qualidade, com baixo vigor e baixo poder germinativo; e) utilização das tecnologias inadequadas. Com relação ao uso das sementes pelos produtores, normalmente, são as mesmas utilizadas em plantio anteriores. As referidas sementes, devido ao sistema de armazenamento nas propriedades, apresentam baixo vigor e baixo poder germinativo.

A Secretaria de Agricultura, Irrigação e Reforma Agrária (1997) publicou um estudo sobre a situação e tendências dos principais produtos em grãos, e argumentou que a produção baiana de milho se resume em duas safras, sendo que a primeira se concentra nas regiões de Irecê, Barreiras e Piemonte da Diamantina com estimativa em torno de 762 mil toneladas. Para a segunda safra, que tem como principais regiões produtoras Nordeste e Paraguaçu com estimativa de 240 mil toneladas de milho. Por se tratar de uma cultura de consórcio, os produtores de milho de sequeiros que na sua maioria são os mesmos de feijão, enfrentam a mesma problemática: falta de recursos para custeio, períodos longos de estiagem na época do plantio e dos tratos culturais. 
Secretaria de Agricultura, Irrigação e Reforma Agrária (1998) publicou um estudo sobre os bons resultados na $2^{\text {a }}$ safra de milho e feijão de sequeiros, e acrescentou que no ano de 1998 as colheitas dos grãos foram marcadas por grandes prejuízos causados pelo El Niño. Durante o plantio de verão, as lavouras mais afetadas pelo fenômeno foram: mamona, feijão, milho, arroz e algodão que acumularam uma perda total de quase 300 mil hectares, agravada ainda com os baixos rendimentos obtidos por área. O cultivo do milho é pouco tecnificado, devido ao fato de a cultura ser utilizada basicamente para subsistência e com a utilização apenas de mão de obra própria. Esses grupos não conseguem contratar trabalhadores fora da propriedade, geralmente por falta de garantias reais, os bancos não Ihes concedem nenhum tipo de crédito agrícola.

Barbosa (2000) realizou um estudo eminentemente geográfico, sobre os impactos da seca de 1993 no semi-árido baiano: o caso de Irecê. Abordou questões importantes sobre as estiagens, começando com a evolução histórica das secas no Nordeste, a ação governamental e as especificidades do semiárido baiano, com destaque para a Região de Irecê. Nessa área de estudo, a autora focalizou o uso dos recursos e os riscos climáticos para a cultura do feijão, os tipos de secas dentro do período de 1944-1994, e os impactos provocados durante os últimos episódios das secas, evidenciando o evento de 92/93 como aquele mais severo e com mais reflexos no crescimento regional.

Ayala-Osuna (2001) focalizou um estudo sobre genética e melhoramento do milho tropical: propostas para aumentar a produtividade e ressaltou as diferentes publicações sobre a história, evolução e origem do milho, além disso, propôs métodos de melhoramento para as condições do semi-árido e 
destacou as características da planta como resistência as condições de seca, solos ácidos e alta salinidade, de maneira a contribuir para o aumento da produtividade agrícola. Este autor argumentou que na região Nordeste as produções do milho são prejudicadas pelas condições edafoclimatológicas, principalmente devido às secas prolongadas que reduzem as taxas de produtividade em torno de 600 a $1200 \mathrm{~kg} / \mathrm{ha}$. No Estado da Bahia, de forma geral, cerca de $70 \%$ da área do Estado na qual se cultiva o milho concentra-se em propriedades com área menor do que 200ha, principalmente na região Além São Francisco, onde municípios tais como Adustina, Angical, Paripiranga e Riachão das Neves possuem propriedades com menos de 200ha. Já nos municípios na qual vem sendo utilizada maior tecnologia na cultura eles figuram entre os principais produtores, por exemplo: Barreiras, São Desidério e Correntina. Desta forma, o grau de concentração é maior, chegando a cerca de $82 \%$ da área colhida com milho em propriedades com mais de $1.000 \mathrm{ha}^{2}$.

Secretaria de Agricultura, Irrigação e Reforma Agrária (2002) publicou um estudo sobre a primeira safra de grãos 2002 na Bahia, e argumentou que do milho produzido na Bahia $60 \%$ provém do oeste baiano, onde o cereal é plantado mais cedo que as demais culturas. Isso o protegeu dos efeitos da estiagem, uma vez que choveu até meados de fevereiro, o suficiente para 0 bom desempenho da lavoura, que obteve rendimento médio de 87 sacas por hectares. As demais regiões não tiveram o mesmo desempenho, sendo que a produtividade total do Estado passou de $2.576 \mathrm{~kg} / \mathrm{ha}$ para $2.433 \mathrm{~kg} / \mathrm{ha}$.

Maia (2003) realizou um estudo sobre a variabilidade climática e a produtividade do milho em espaços paulistas para analisar a relação do clima versus produtividade do milho, e argumentou que milho na safra verão é 
plantado em outubro a novembro, e nos meses de março a abril a produção já está definida, tornando a distribuição e a quantidade da precipitação, um fator fundamental para o desenvolvimento da cultura do milho, principalmente nos meses de outubro a março, período este que coincide com o ciclo vegetativo do cereal. A cultura do milho, com a ausência de água durante as fases de formação da espiga, reprodução e enchimento dos grãos (outubro a janeiro) são reconhecidas como as causas determinantes das menores produtividades, com a indicação dos parâmetros hídricos fornecidos pelo Balanço Hídrico. O autor explanou que se faz necessário a formulação de políticas e estratégias para o desenvolvimento rural regional de curto prazo, para diminuir as perdas na produtividade agrícola paulista e elevar a economia deste importante Estado brasileiro.

Moraes e Ferreira Filho (2011) realizaram um estudo sobre a economia das alterações climáticas e a agricultura baiana, neste trabalho os autores ressaltaram a perspectiva de ocorrência de alterações climáticas e suas repercussões na agricultura. Além disso, apresentaram resultados para a atividade econômica, mercado de trabalho e perfil de consumo das famílias para o estado da Bahia a partir de cenários de alterações climáticas. Através de um modelo de equilíbrio geral computável, estimou-se que o produto interno bruto possa cair até 2,3\% em um cenário mais severo, apenas considerando os efeitos na agricultura. Resultados para o mercado de trabalho e perfil de consumo também indicaram a possibilidade de uma maior desigualdade de renda a partir das alterações climáticas. 


\section{METODOLOGIA}

\subsection{BASES DE DADOS}

Das bases de dados adquiridas, uma se referiu a dados de produtividade da cultura do milho, e a outra aos dados de chuva da área em estudo. Para a primeira, as fontes de busca foram Instituto Brasileiro de Geografia e Estatística (IBGE), por meio do acervo PAM (Produção Agrícola Municipal) para a série temporal compreendida de 1990 a 2010, totalizando 21 anos de estudo. A série temporal iniciou em 1990, por causa da criação do PAM neste mesmo ano. O IBGE também disponibilizou dados de quantidade produzida e área colhida para o mesmo período em estudo.

A segunda base de dados se refere aos dados pluviométricos que foram retirados de duas fontes: a primeira Agência Nacional de Águas (ANA) e a segunda a Estação Climatológica do Campus da Universidade Estadual de Feira de Santana no município de Feira de Santana (Bahia). A Agência Nacional de Águas (ANA) disponibilizou dados de chuva apenas dois municípios da microrregião de Feira de Santana que são os municípios de Teodoro Sampaio e Rafael Jambeiro para o período de 1990 a 2010.

Por conseguinte, utilizamos os dados de chuvas extraídos da Estação Climatológica, pertencente ao IV Distrito do Instituto Nacional de Meteorologia (INMET) localizada no Campus da Universidade Estadual de Feira de Santana no município de Feira de Santana (Bahia), apresenta as seguintes coordenadas geográficas $12^{\circ} 12^{\prime} 08^{\prime \prime} \mathrm{S}$ e $38^{\circ}{ }^{\circ} 8^{\prime} 15^{\prime \prime} \mathrm{O}$. A série pluviométrica e de temperatura disponibilizada pela Estação Climatológica se refere ao período 
de 1994 a 2010, uma vez que só começou a funcionar em março de 1993, por isso só foram estudados os dados pluviométricos e de temperatura a partir de 1994, pois em 1993 foi um ano experimental e de adaptações.

\subsection{PROCEDIMENTOS METODOLÓGICOS PARA A EVOLUÇÃO ESPAÇO- TEMPORAL DA CULTURA DO MILHO NA ÁREA DE ESTUDO}

Os dados agrícolas utilizados na análise da evolução espaço-temporal envolveram três variáveis: quantidade produzida (ton), área colhida (ha) e produtividade agrícola (ton/ha), referentes aos períodos de 1990 a 2010 para os municípios de Teodoro Sampaio e Rafael Jambeiro, e de 1994 a 2010 para o município de Feira de Santana. Utilizando os dados de quantidade produzida e área colhida se calculou os dados de produtividade

$$
\text { Produt }=\operatorname{Prod} / \mathrm{A}
$$

$$
\begin{aligned}
& \text { Produt = produtividade (ton/ha) } \\
& \text { Prod = quantidade produzida (ton) } \\
& \text { A = área colhida (há) }
\end{aligned}
$$

Os dados dessas três variáveis foram organizados em planilhas do software Excel e seus resultados apresentados em tabelas e gráficos, sendo utilizados também em geração de mapas pelo ArcMap. 


\subsection{PROCEDIMENTOS METODOLÓGICOS PARA A ANÁLISE DA PLUVIOMETRIA NA ÁREA DE ESTUDO}

Para a análise dos dados foram utilizadas as médias diárias, mensais e anuais da precipitação pluviométrica, das quais possibilitaram o conhecimento da variabilidade climática dos municípios Teodoro Sampaio, Feira de Santana e Rafael Jambeiro. Utilizou-se a média aritmética e o desvio em relação à média. Os desvios em relação à média é a diferença entre cada elemento de um conjunto de valores e a média aritmética. $\mathrm{O}$ desvio pode ser calculado pela seguinte equação:

$$
d_{i}=x_{i}-\bar{x}
$$

$d_{i}$ é o desvio em relação à média;

$x_{i}$ o valor da precipitação pluviométrica;

$x$ é a média aritmética.

Foram realizados testes de correlação linear para os desvios de precipitação pluviométrica e para os desvios de produtividade do milho para os três municípios em estudo, para entender o quanto esses dois elementos são interligados. Foram feitos gráficos e calculada a distribuição e frequência da amostra, a correlação e sua significância estatística. Para este cálculos foram utilizadas: a) as séries temporais de toda a série histórica, com dados mensais; b) os dados totais anuais; c) anomalias para os dados mensais; d) anomalias para os dados anuais. A depender do tamanho da amostra, o valor de $r$ exigido para a significância da correlação pode variar. 


\subsection{TÉCNICAS DE PESQUISA}

Na pesquisa direta procedeu-se ao levantamento de informações por meio de trabalho de campo para o reconhecimento da área de estudo na microrregião de Feira de Santana. O trabalho de campo permitiu uma aproximação do pesquisador da realidade sobre a qual formulou o problema, além de estabelecer uma interação com os agentes que conformam à realidade, assim, construindo um conhecimento empírico importantíssimo para a pesquisa. É importante ressaltar que a observação foi não-participante, na qual o pesquisador toma contato com a realidade estudada sem integrá-la.

A pesquisa indireta foi realizada à pesquisa documental (fonte de pesquisa primária) e pesquisa bibliográfica (fonte de pesquisa secundária). $\mathrm{Na}$ pesquisa documental foram focalizados os dados de chuvas de 1990 a 2010, além dos dados de produtividade do milho fornecido pelo IBGE para o mesmo período. Na pesquisa bibliográfica foram consultados diversos trabalhos como obras específicas, artigos publicados em revistas e periódicos especializados. 


\section{RESULTADOS}

As Figuras 13, 14 e 15 apresentam a distribuição dos totais pluviométricos dos municípios de Teodoro Sampaio (1990 a 2010), Feira de Santana (1994 a 2010) e Rafael Jambeiro (1990 a 2010). Em Teodoro Sampaio é possível perceber as menores precipitações pluviométricas nos anos de 1993 (541 mm), 1998 (839,6 mm) e 2009 (702,1 mm). No município de Feira de Santana as menores precipitações pluviométricas foram nos anos de 1995 (594,2 mm), 1998 (592,6 mm), e 2001 (619,6 mm). O município Rafael Jambeiro, por sua vez, as menores precipitações pluviométricas foram os anos 1993 (269,3 mm), 1996 (399,5 mm), 2003 (388,6 mm).

Diante das Figuras 13, 14 e 15 é possível notar que as maiores precipitações no município de Teodoro Sampaio foram nos anos de 1996 (1300,9 mm), 1999 (1399,9 mm) e 2000 (1330,6 mm). No município de Feira de Santana as maiores precipitações pluviométricas foram nos anos de 1994 (1038 mm), 1996 (886,5 mm), e 1997 (924 mm). O município Rafael Jambeiro, por sua vez, as maiores precipitações pluviométricas foram 1991 (867,9 mm), 1995 (855,9 mm), e 1997 (973,2 mm). 


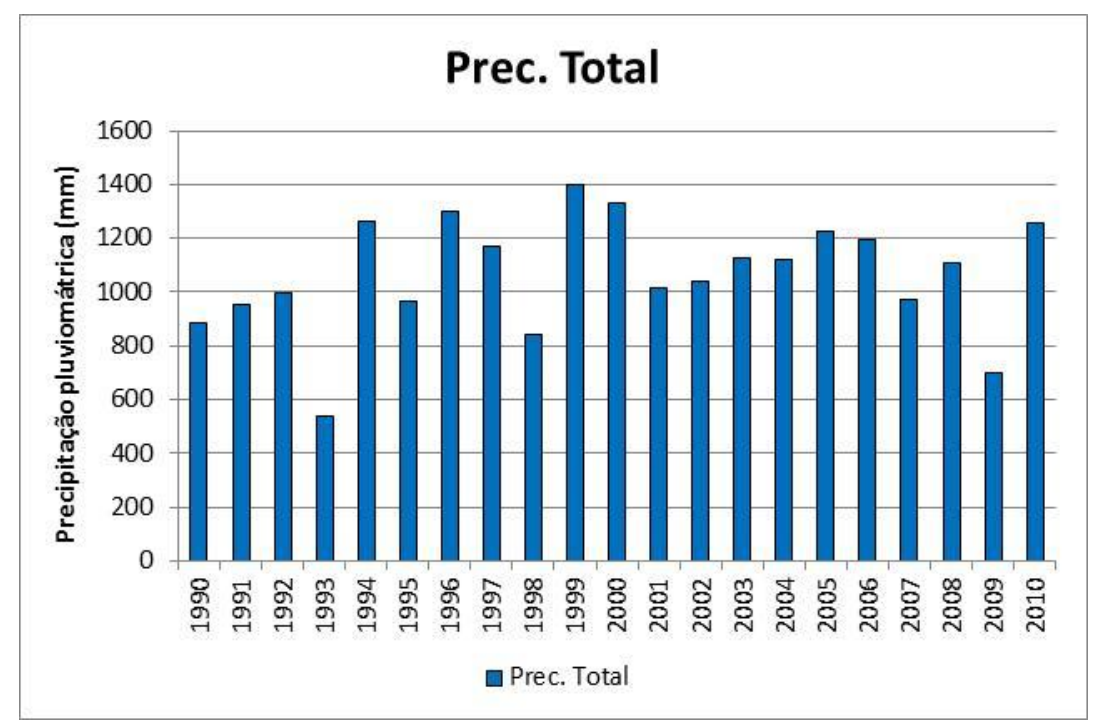

Figura 13: Totais pluviométricos do município de Teodoro Sampaio no período de 1990 a 2010.

Fonte: ANA (2013)

Elaboração: DINIZ (2014)

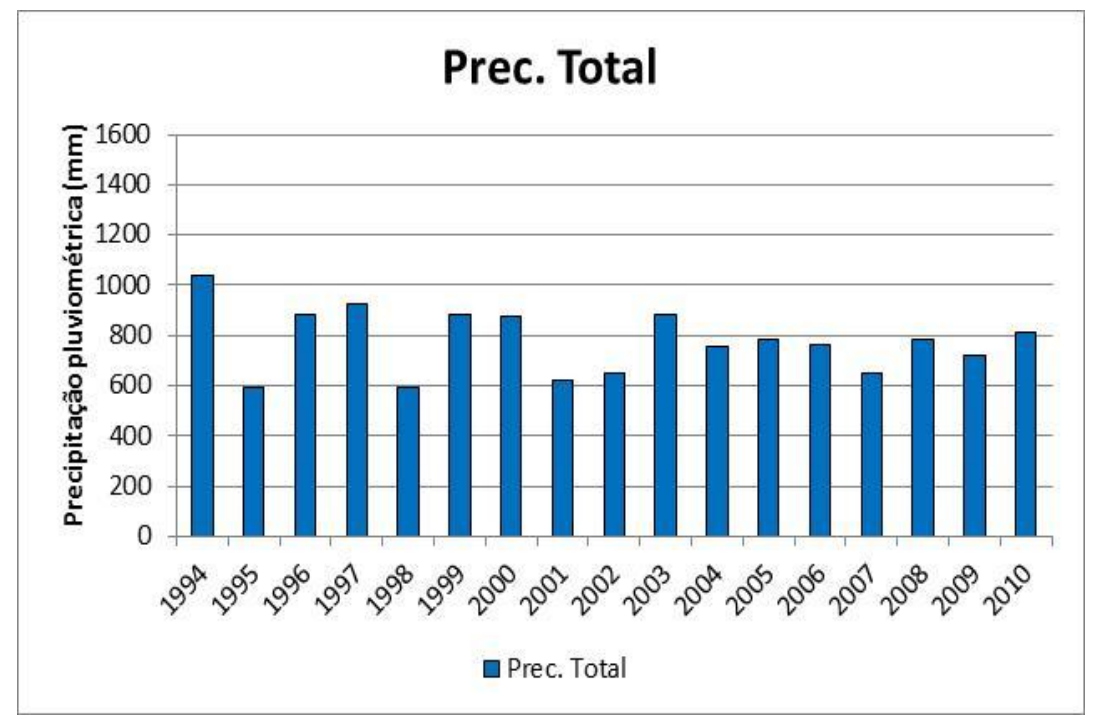

Figura 14: Totais pluviométricos do município de Feira de Santana no período de 1994 a 2010. Fonte: ANA (2013)

Elaboração: DINIZ (2014) 


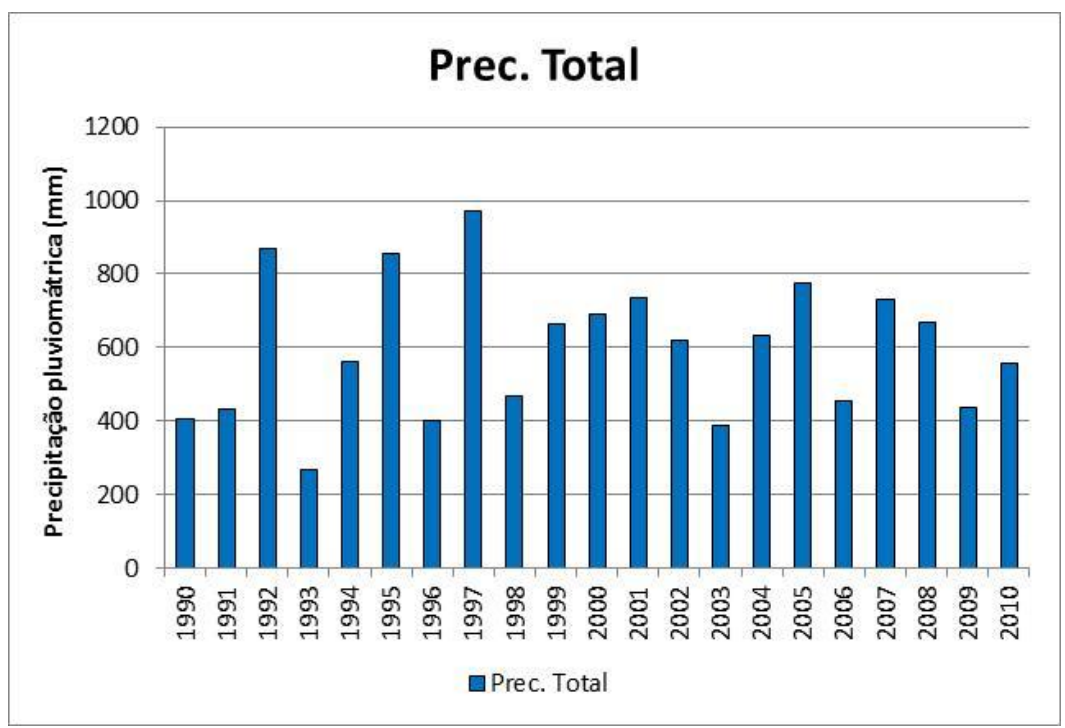

Figura 15: Totais pluviométricos do município de Rafel Jambeiro no período de 1990 a 2010. Fonte: Estação Climatológica/ UEFS (2013) Elaboração: DINIZ (2014)

É possível perceber ao analisar as Figuras 16, 17 e 18 que os meses mais secos das séries históricas em estudo são: no município Teodoro Sampaio: janeiro, outubro e dezembro. Nos municípios de Feira de Santana e Rafael Jambeiro agosto, setembro e outro.

Os meses mais chuvosos são: Teodoro Sampaio maio, junho e julho. No município de Feira de Santana são os meses de abril, junho e novembro. Em Rafael Jambeiro os meses mais chuvosos são janeiro, fevereiro e março. É possível observar nas Figuras 16, 17 e 18 que o mês de março de 1997 teve grande expressividade nos volumes de precipitações pluviométricas, em Teodoro Sampaio (267,5 mm), Feira de Santana (352,8 mm) e Rafael Jambeiro $(423,3 \mathrm{~mm})$.

Segundo Aouad (1983) através de estudos desenvolvidos pela SEPLANTEC comprovou o grau de participação da Frente Polar Atlântica (FPA) na produção de chuvas, correlacionando os índices pluviométricos com a 
atuação das correntes atmosféricas. Constatou a existência de estreita relação entre o número de passagens das frentes frias e as chuvas, durante todo 0 ano. Os meses secos estavam relacionados à frequência dos alísios de sudeste. A estrutura pluvial na Microrregião de Feira de Santana é bastante irregular não só quanto à distribuição espacial da pluviosidade bem como a duração dos períodos secos e chuvosos.

Essa irregularidade é capaz de desorganizar a agricultura de sequeiros, na qual depende da precipitação pluviométrica para seu desenvolvimento. Como citadas por Fancelli e Lima (1982) "as deficiências hídricas podem afetar sensivelmente o processo germinativo, comprometendo o estabelecimento da cultura, deficiências posteriores podem paralisar o crescimento, bem como retardar o desenvolvimento reprodutivo das plantas". 

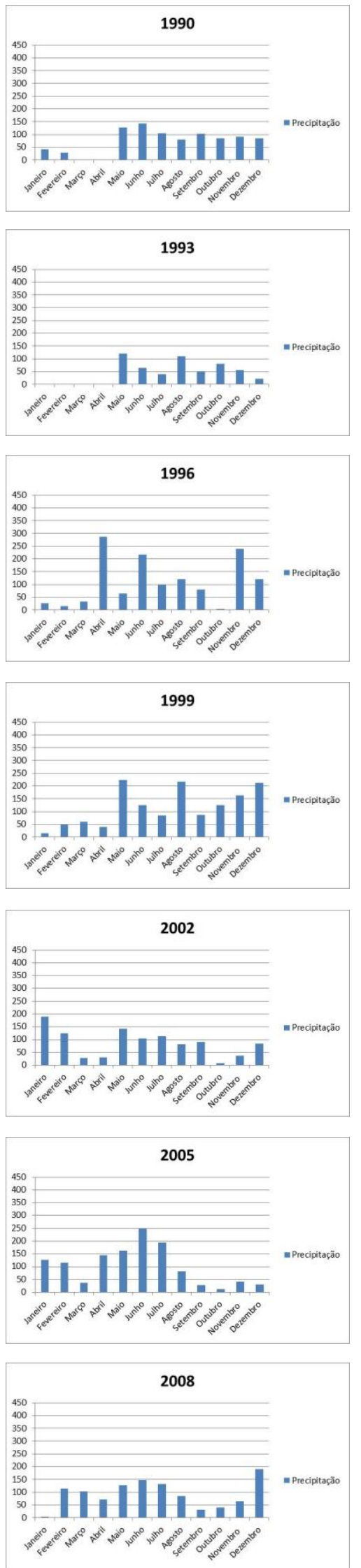

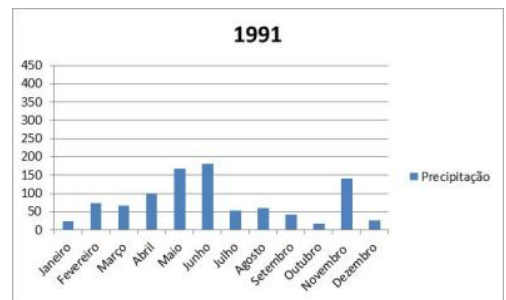

1994
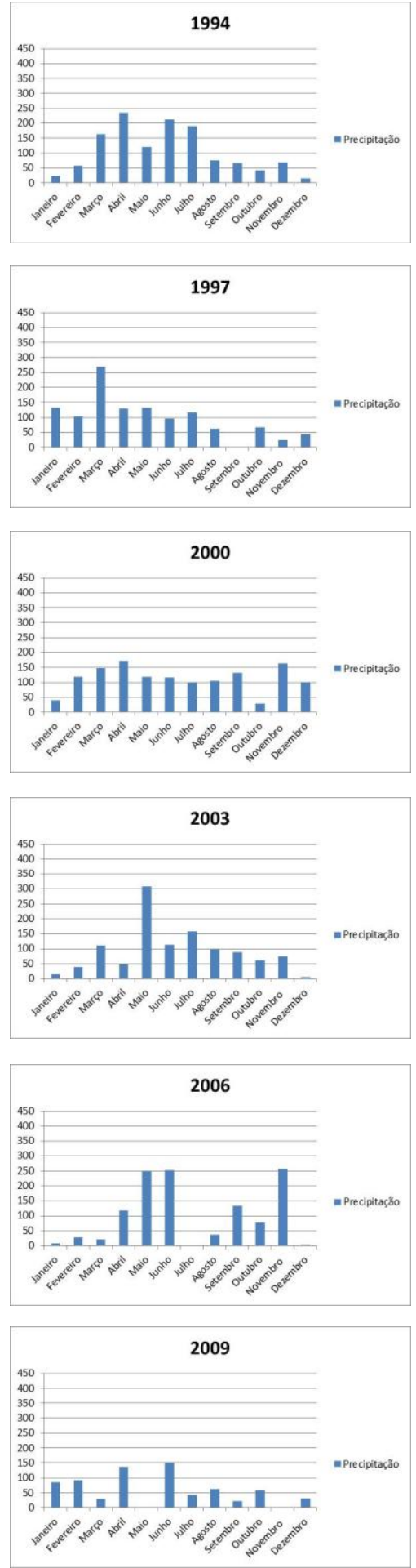
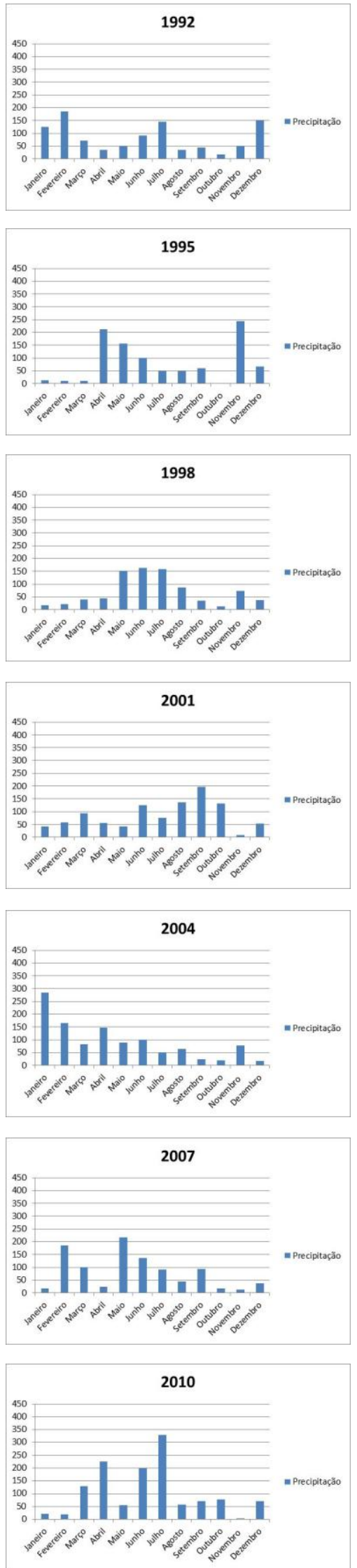

Figura 16: Dados pluviométricos médios mensais do município de Teodoro Sampaio (1990 a 2010).

Fonte: ANA (2013)

Elaboração: DINIZ (2016) 

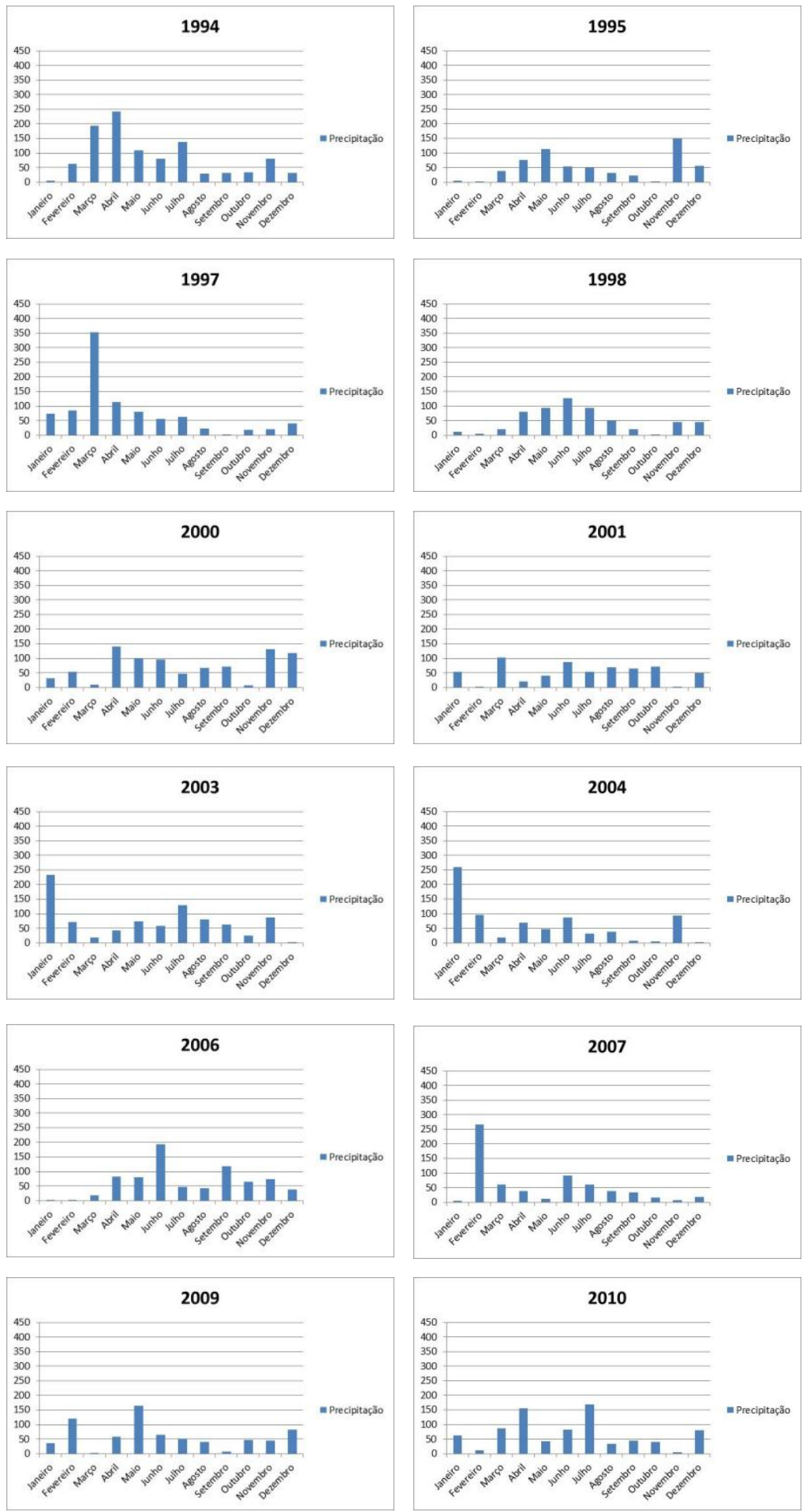
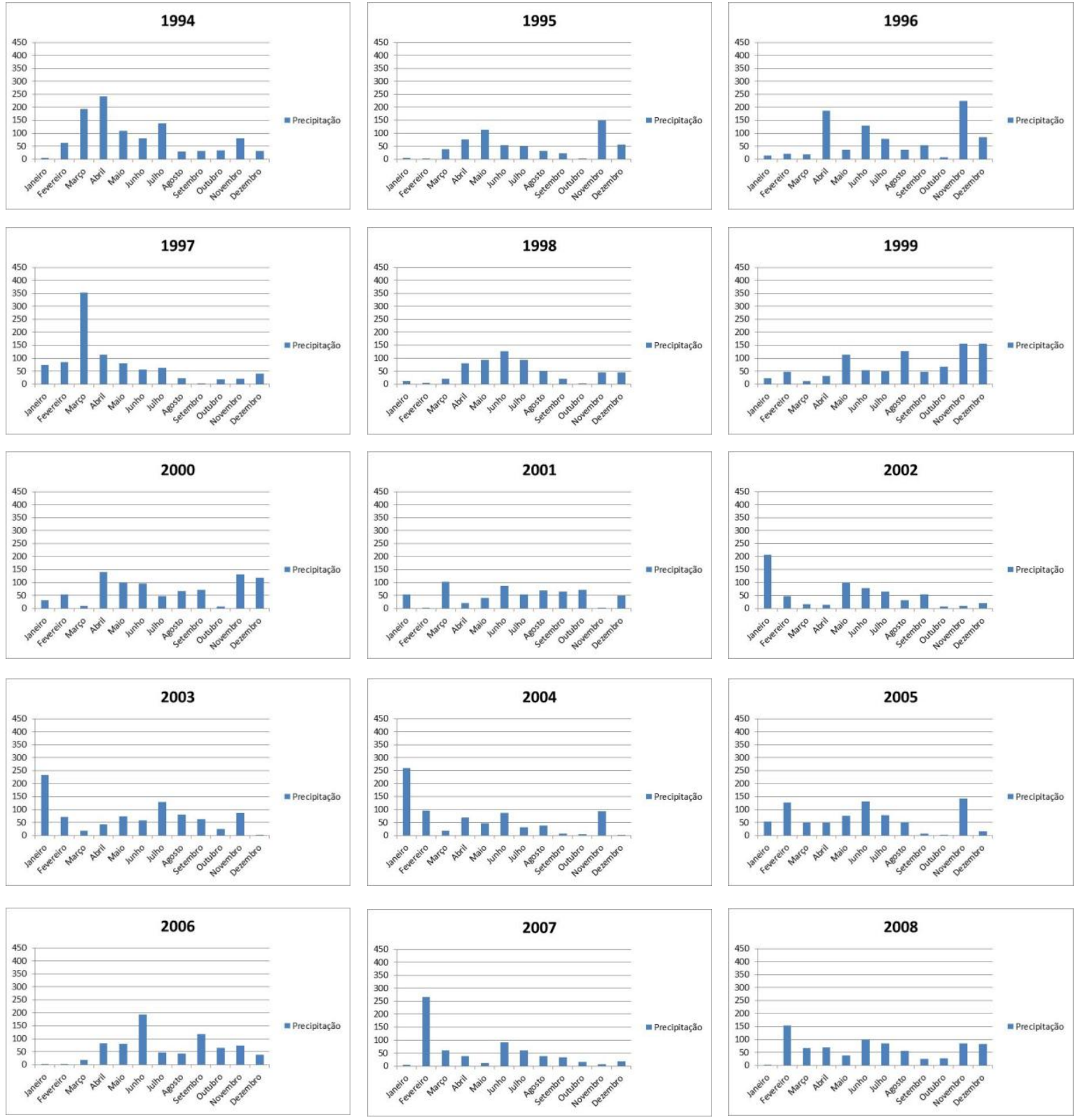

Figura 17: Dados pluviométricos médios mensais do município de Feira de Santana (1994 a 2010).

Fonte: Estação Climatológica/UEFS (2012)

Elaboração: DINIZ (2016) 


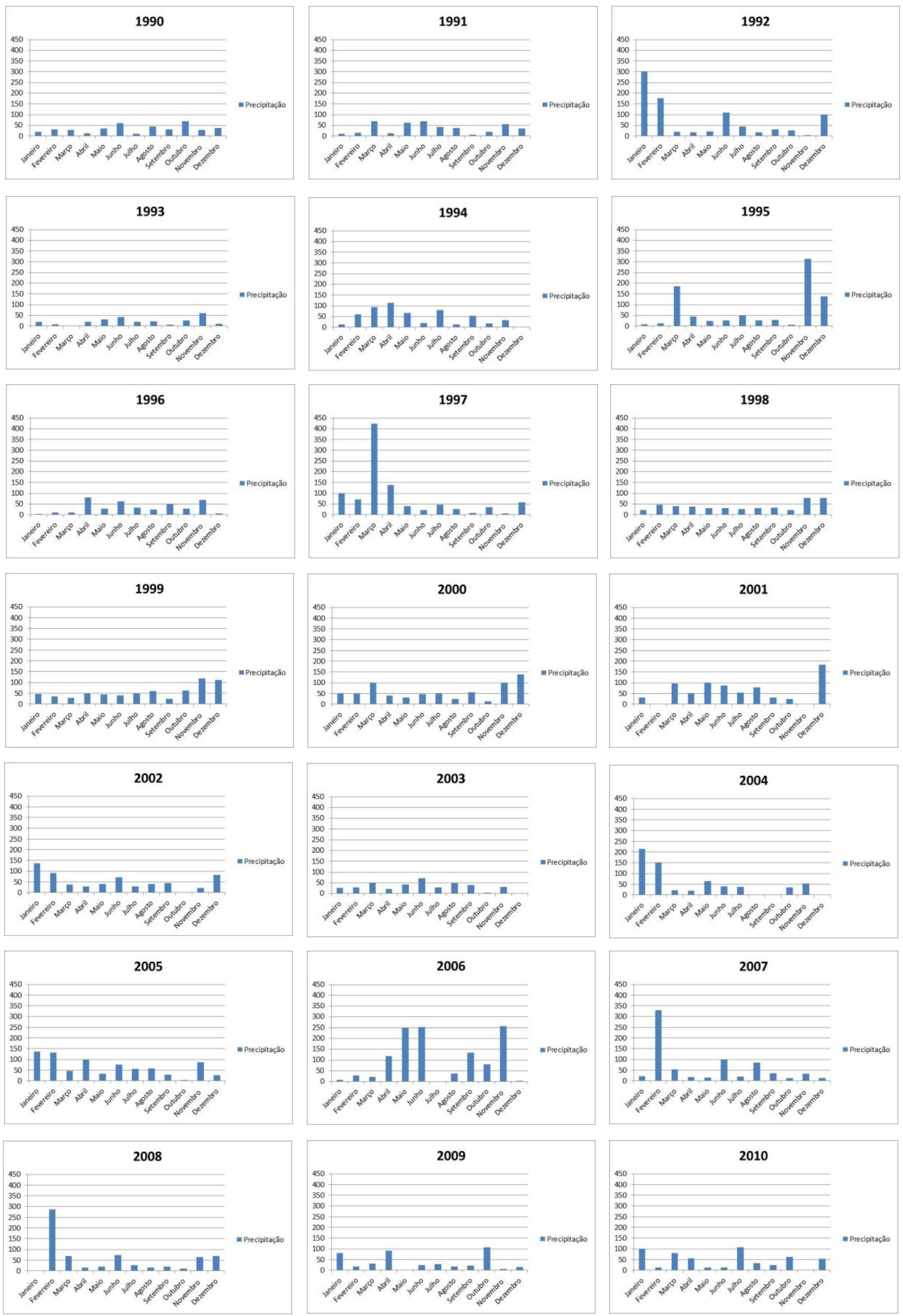

Figura 18: Dados pluviométricos médios mensais do município de Rafael Jambeiro (1990 a 2010). Fonte: ANA (2013)

Elaboração: DINIZ (2016) 
As Figuras 19, 20, 21 e 22 retratam a variabilidade sazonal da precipitação pluviométrica nos municípios em estudo, foi possível observar que as chuvas são menores na primavera e no verão, já no outono e inverno o volume das chuvas são maiores. Isto se justifica pelo sistema de circulação perturbada de leste que é mais frequente no inverno e outono, enquanto que na primavera e verão são menos frequentes. Por isso, mais seco na primavera e mais chuvoso no outono na Microrregião de Feira de Santana. Como já discutido, e de acordo com Nimer (1977) "as ondas de leste caminham de leste para oeste, e são característicos dos litorais da zona tropical adentrando ao continente, na qual são atingidos pelos alísios [...] as precipitações devidas a este fenômeno diminuem bruscamente para oeste, adentrando ao continente".

Barbosa (2000) argumentou que o agreste baiano é sub-região do Nordeste na qual está inserida a Microrregião de Feira de Santana, situada entre o litoral e o interior, sendo está uma zona de transição, ocasionalmente, beneficia-se das precipitações do litoral, podendo ocorrer os períodos chuvosos pela superposição dos sistemas atmosféricos atuantes. Além disso, é importante ressaltar Cavalcanti et al. (2009) que ressaltou que o escoamento médio e a brisa terra-mar ocasionam um máximo noturno ao longo da costa e um máximo diurno até $300 \mathrm{~km}$ distante da costa, e a Microrregião em estudo está localizada na abrangência dos 300 km da costa litorânea. 


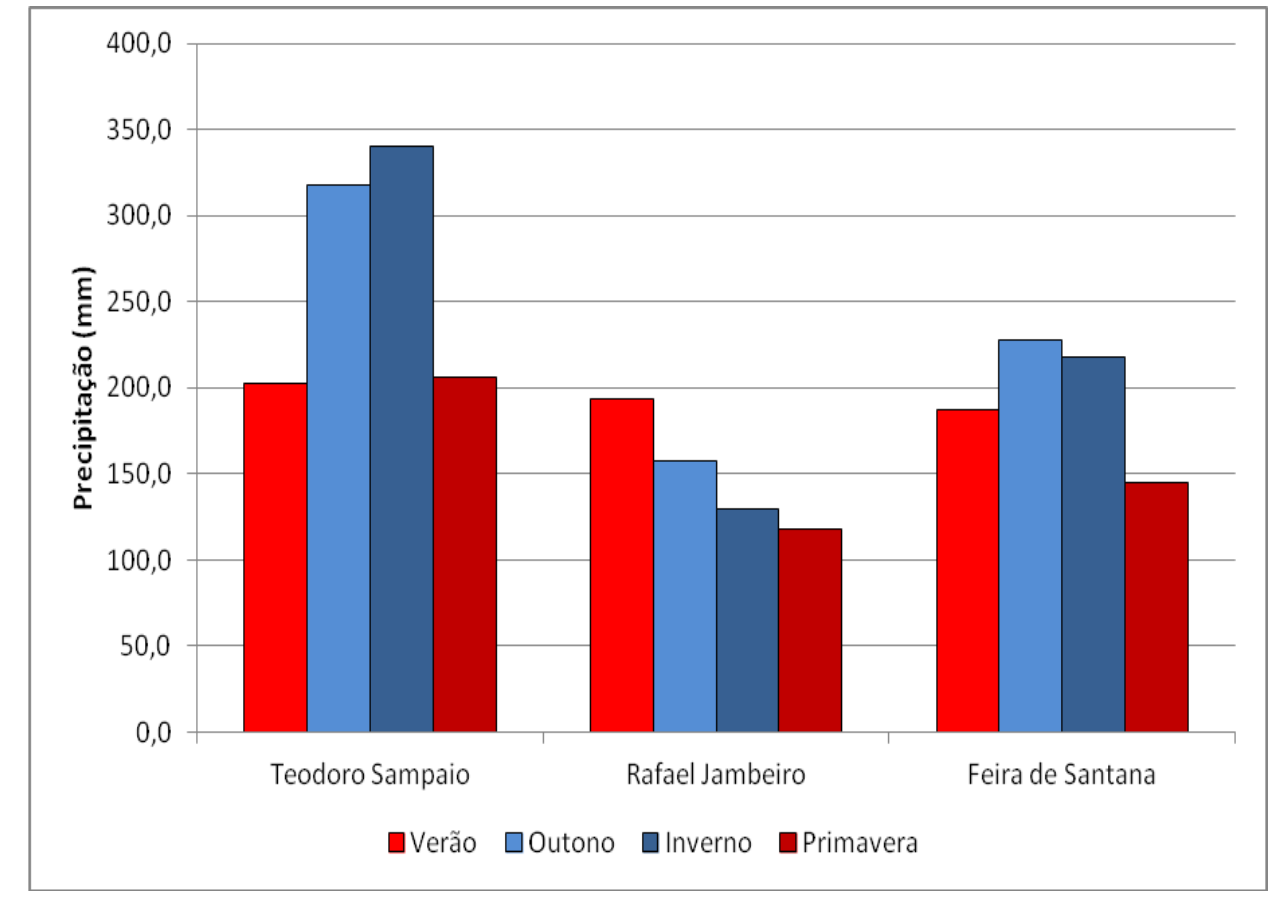

Figura 19: Dados pluviométricos sazonais dos municípios em estudo da Microrregião de Feira de Santana: Teodoro Sampaio, Rafael Jambeiro e Feira de Santana.

Fonte: ANA (2013) e Estação Climatológica/UEFS (2012)

Elaboração: DINIZ (2016)

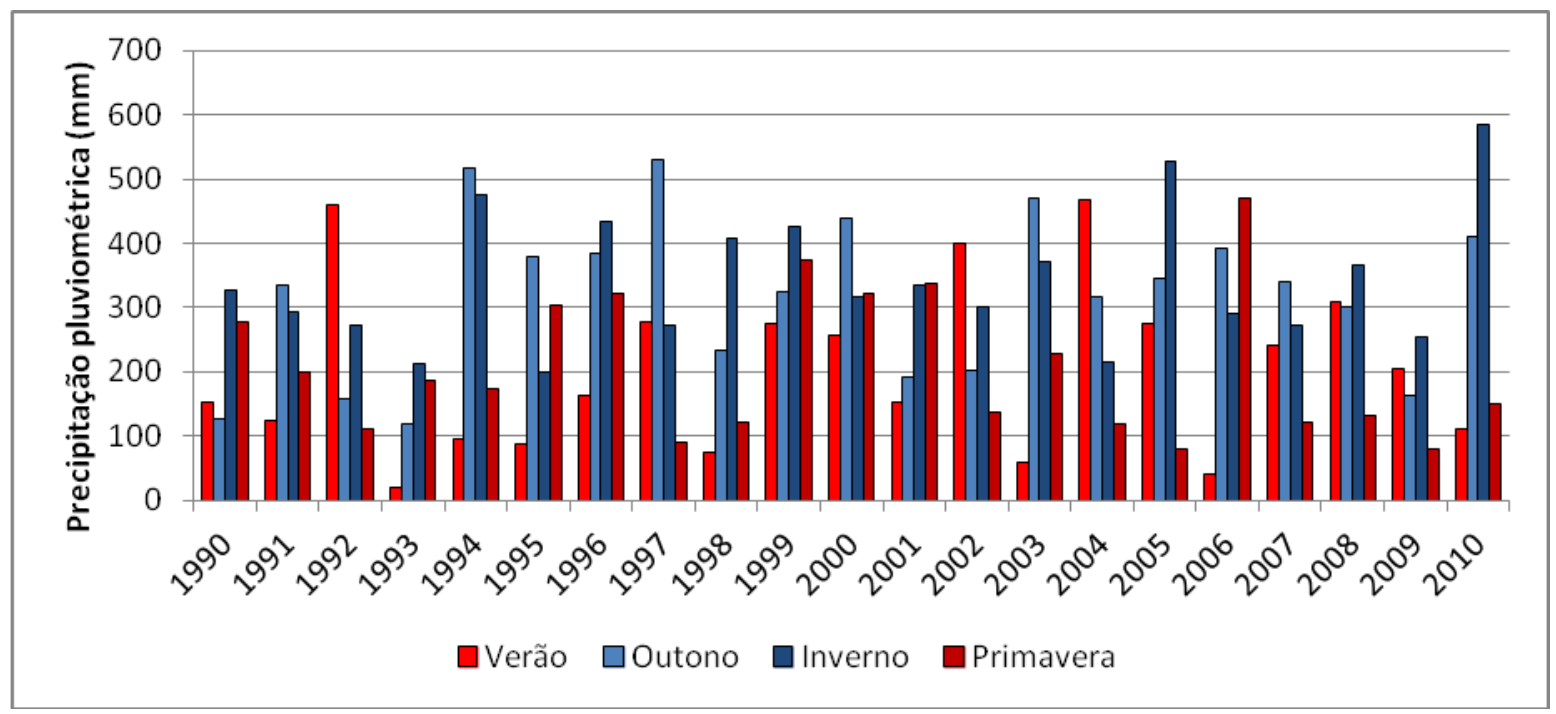

Figura 20: Dados pluviométricos sazonais do município de Teodoro Sampaio (1990 a 2010). Fonte: ANA (2013)

Elaboração: DINIZ (2015) 


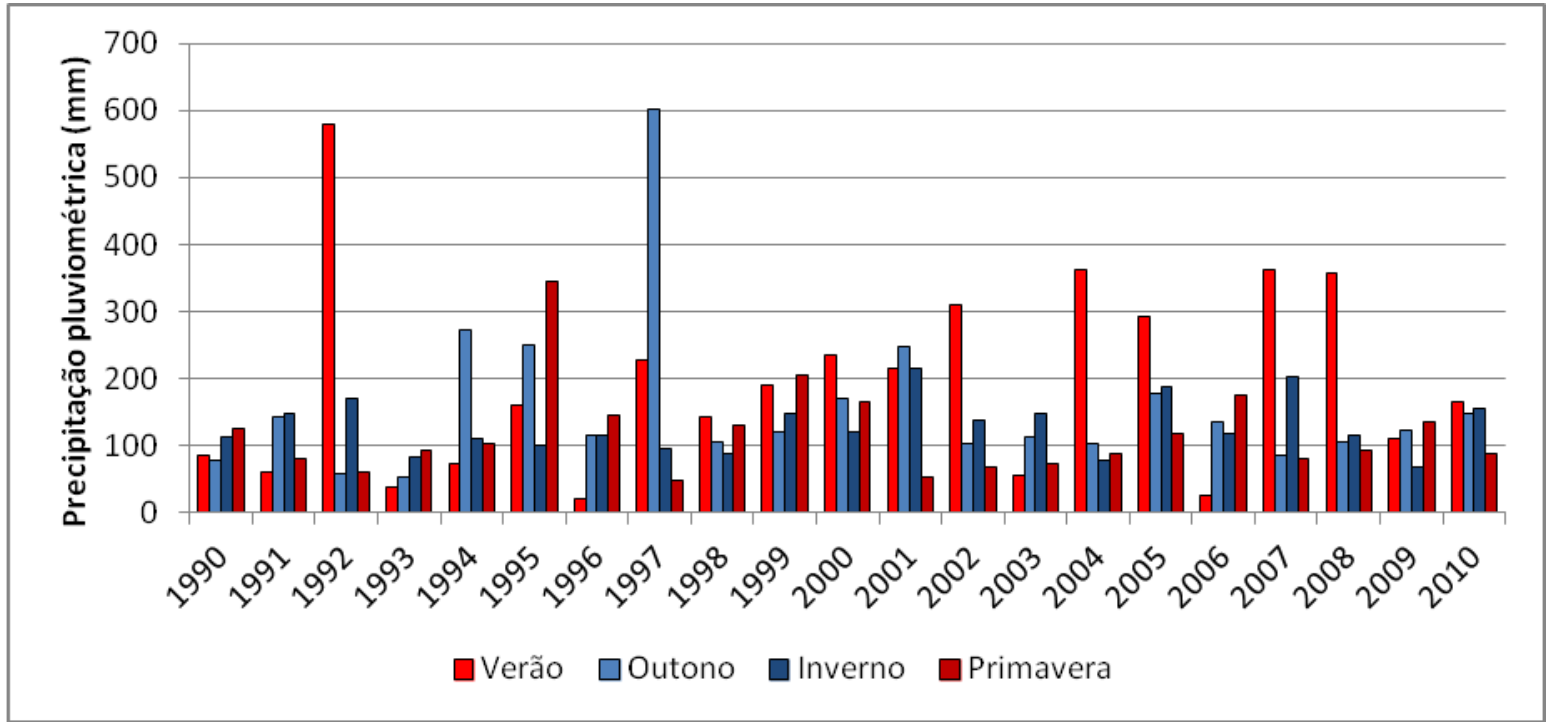

Figura 21: Dados pluviométricos sazonais do município de Feira de Santana (1994 a 2010). Fonte: Estação Climatológica/UEFS (2012)

Elaboração: DINIZ (2015)

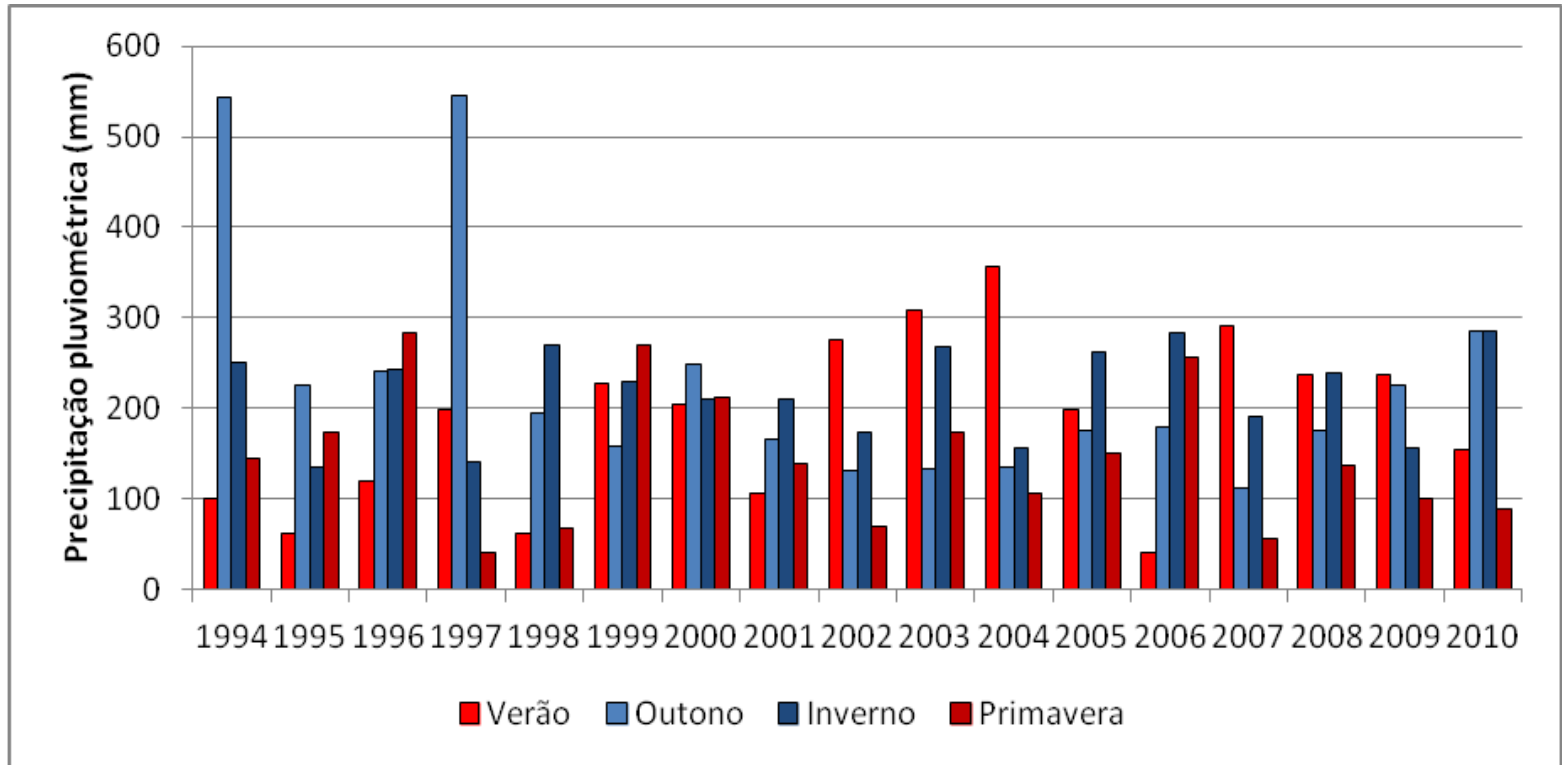

Figura 22: Dados pluviométricos sazonais do município de Rafael Jambeiro (1990 a 2010).

Fonte: ANA (2013)

Elaboração: DINIZ (2015) 
Alguns anos de ocorrência do ENOS (El Niño) coincidem com os anos que obtiveram totais pluviométricos abaixo da média do período. Em Teodoro Sampaio as menores precipitações pluviométricas aconteceram em anos que ocorreu o ENOS como 1993 (forte), 1998 (forte) e 2009 (fraco). Em Feira de Santana as menores precipitações foram 1995 (moderado), 1998 (forte), com exceção de 2001, na qual não houve a ocorrência deste fenômeno. Em Rafael Jambeiro 1993 (forte), 1996 (não ocorreu), e 2003 (moderado). Segundo Caviedes (1975) foi observado "uma forte coincidência entre anos de ocorrência do fenômeno oceanográfico El Niño e as secas no Nordeste" (Quadro 01).

Quadro 01: Intensidade do fenômeno El Niño (ENOS/Oscilação Sul) no período entre 1990 a 2010.

\begin{tabular}{|c|c|}
\hline Anos & Intensidade do ENOS \\
\hline 1990 & Forte \\
\hline 1991 & Forte \\
\hline 1992 & Forte \\
\hline 1993 & Forte \\
\hline 1994 & Moderado \\
\hline 1995 & Moderado \\
\hline 1996 & - \\
\hline 1997 & Forte \\
\hline 1998 & Forte \\
\hline 1999 & - \\
\hline 2000 & - \\
\hline 2001 & - \\
\hline 2002 & Moderado \\
\hline 2003 & Moderado \\
\hline 2004 & Fraco \\
\hline 2005 & Fraco \\
\hline 2006 & Fraco \\
\hline 2007 & Fraco \\
\hline 2008 & - \\
\hline 2009 & Fraco \\
\hline 2010 & Fraco \\
\hline
\end{tabular}

Fonte: Disponível em http://enos.cptec.inpe.br/tab_elnino.shtml. Acesso em 15 de maio de 2016. 
Segundo Aragão (2000) "o ano de 1998 apresentou-se como ano seco, com base em 67 estações meteorológicas". Além disso, este autor comentou que "o ano de 1997 apresentou uma redução na quantidade de chuva entre 30 a 50\%, o déficit hídrico foi intensificado em 1998 com grandes impactos na agricultura [...]". As ideias de Aragão (2000) são esclarecedoras, quando ditas sobre a influência deste fenômeno nos anos de 1997 e 1998, dando um suporte teórico para as repercussões nos municípios em estudo da microrregião de Feira de Santana.

Com relação à agricultura de sequeiros na Microrregião de Feira de Santana, as Figuras 23 a 43 retratam a produtividade da cultura do milho, é possível avaliar temporalmente e espacialcialmente a produtividade dessa cultura na Microrregião de Feira de Santana, que diminui a produtividade na maneira que se avança para o interior da Bahia. Quanto mais próximo do oceano, a influencia dos sistemas atmosféricos e oceanicos interferem na cultura do milho, aumentando a produtividade agrícola.

Quanto mais se adentra ao continente, é possível perceber uma redução no volume das chuvas, e o empobrecimento da fertilidade dos solos, reduzindo a produtividade do milho, que não depende do sistema de irrigação para seu desenvolvimento. Uma vez que, diferentemente do oeste baiano, onde a agricultura é voltada para o agronegócio, tecnificada e moderna, a agricultura na Microrregião de Feira de Santana é desenvolvida em pequenas propriedades rurais, e depende das condições edafoclimáticas para seu desenvolvimento. 


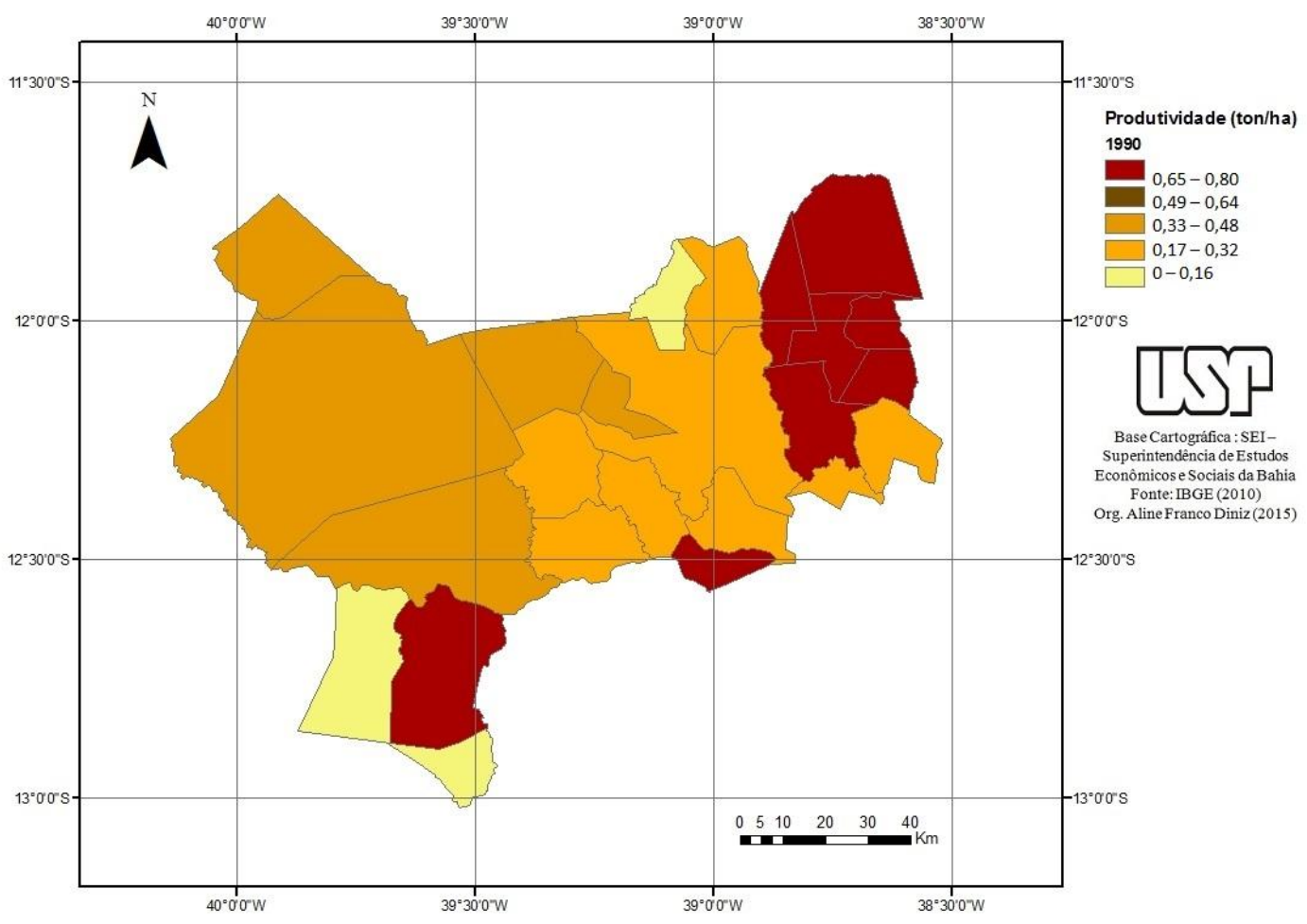

Figura 23: Avaliação temporal e espacial da produtividade da cultura do milho na Microrregião de Feira de Santana (1990).

Fonte: PAM, IBGE (2013)

Elaboração: DINIZ (2015)

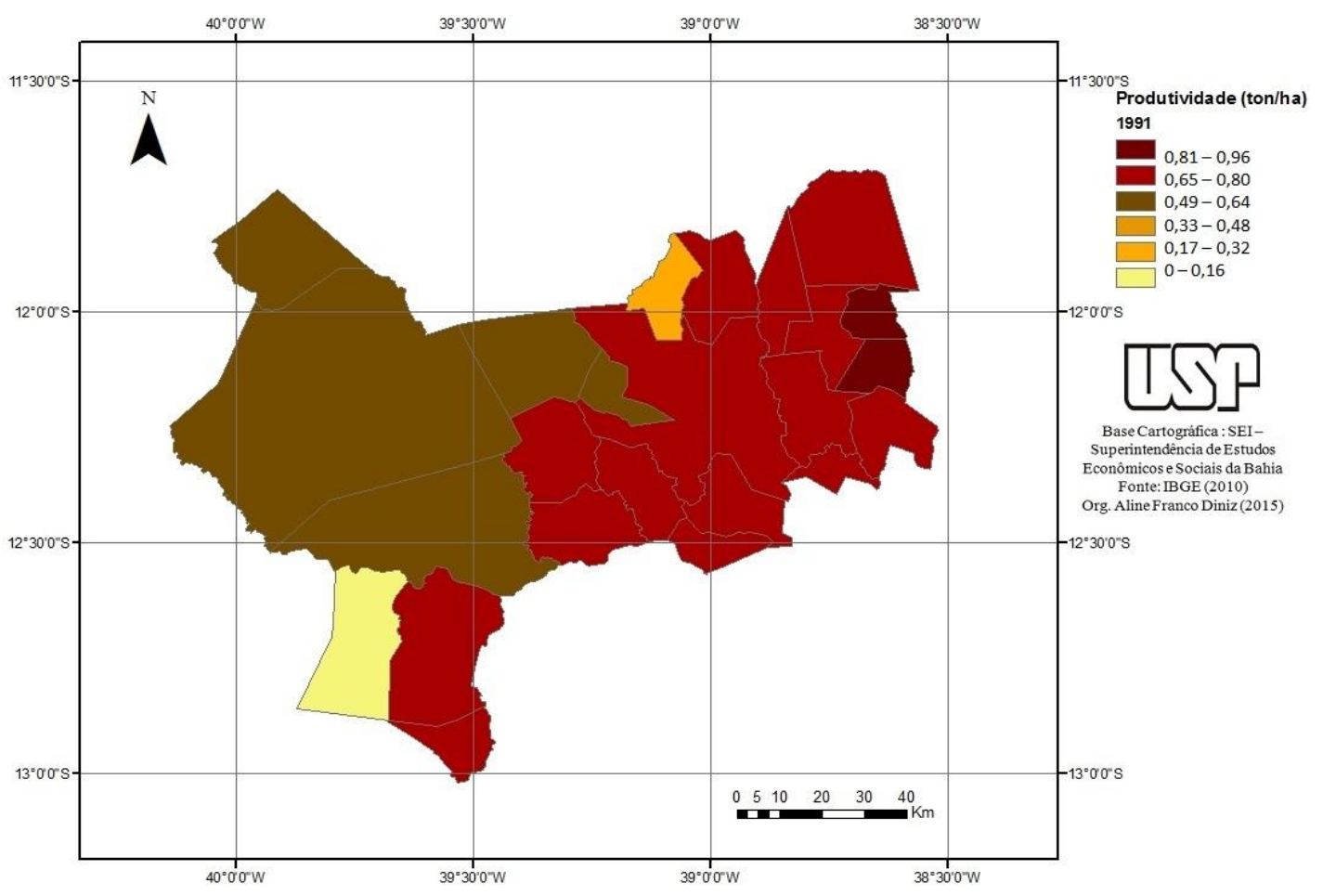

Figura 24: Avaliação temporal e espacial da produtividade da cultura do milho na Microrregião de Feira de Santana (1991).

Fonte: PAM, IBGE (2013)

Elaboração: DINIZ (2015) 


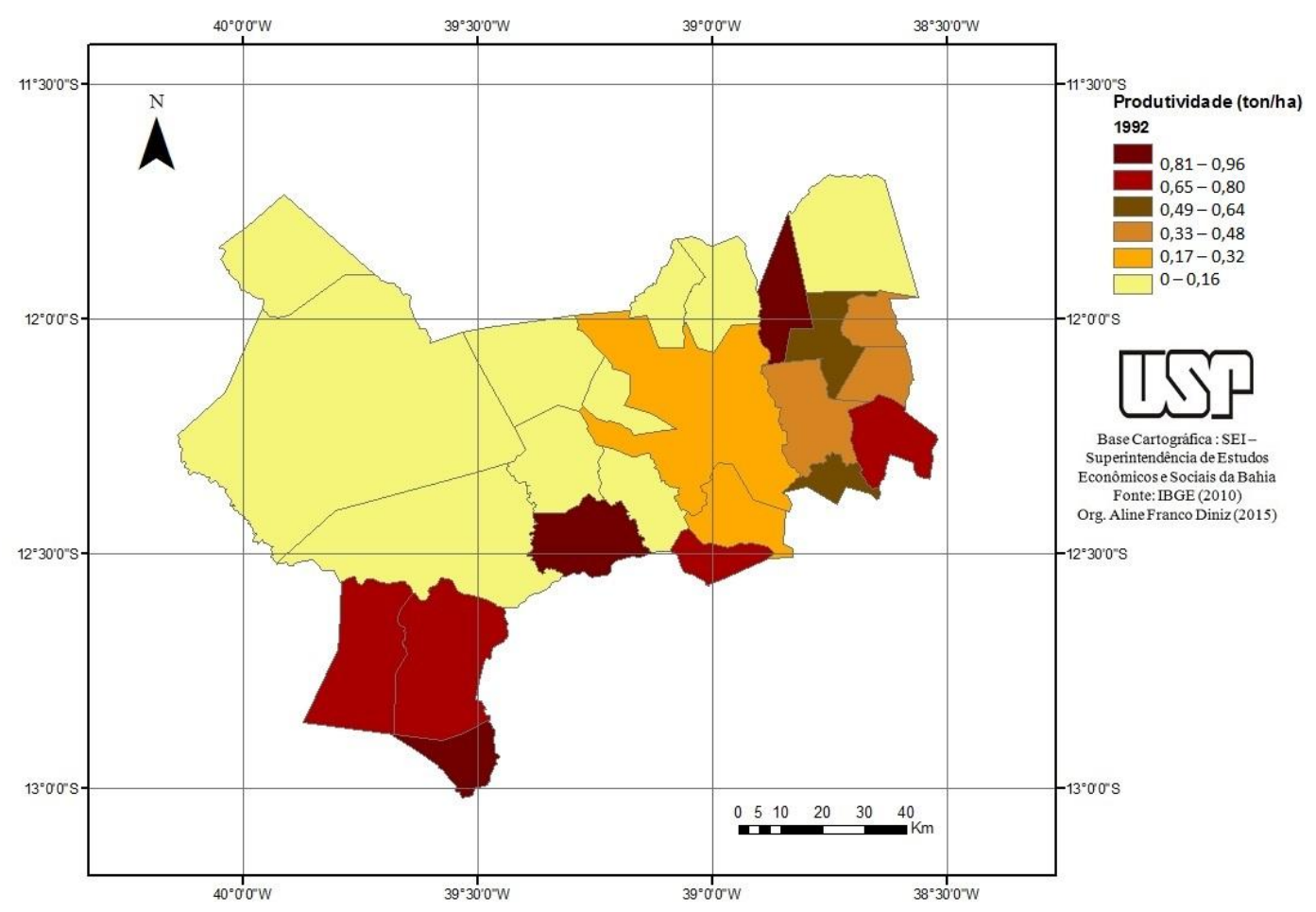

Figura 25: Avaliação temporal e espacial da produtividade da cultura do milho na Microrregião de Feira de Santana (1992).

Fonte: PAM, IBGE (2013)

Elaboração: DINIZ (2015)

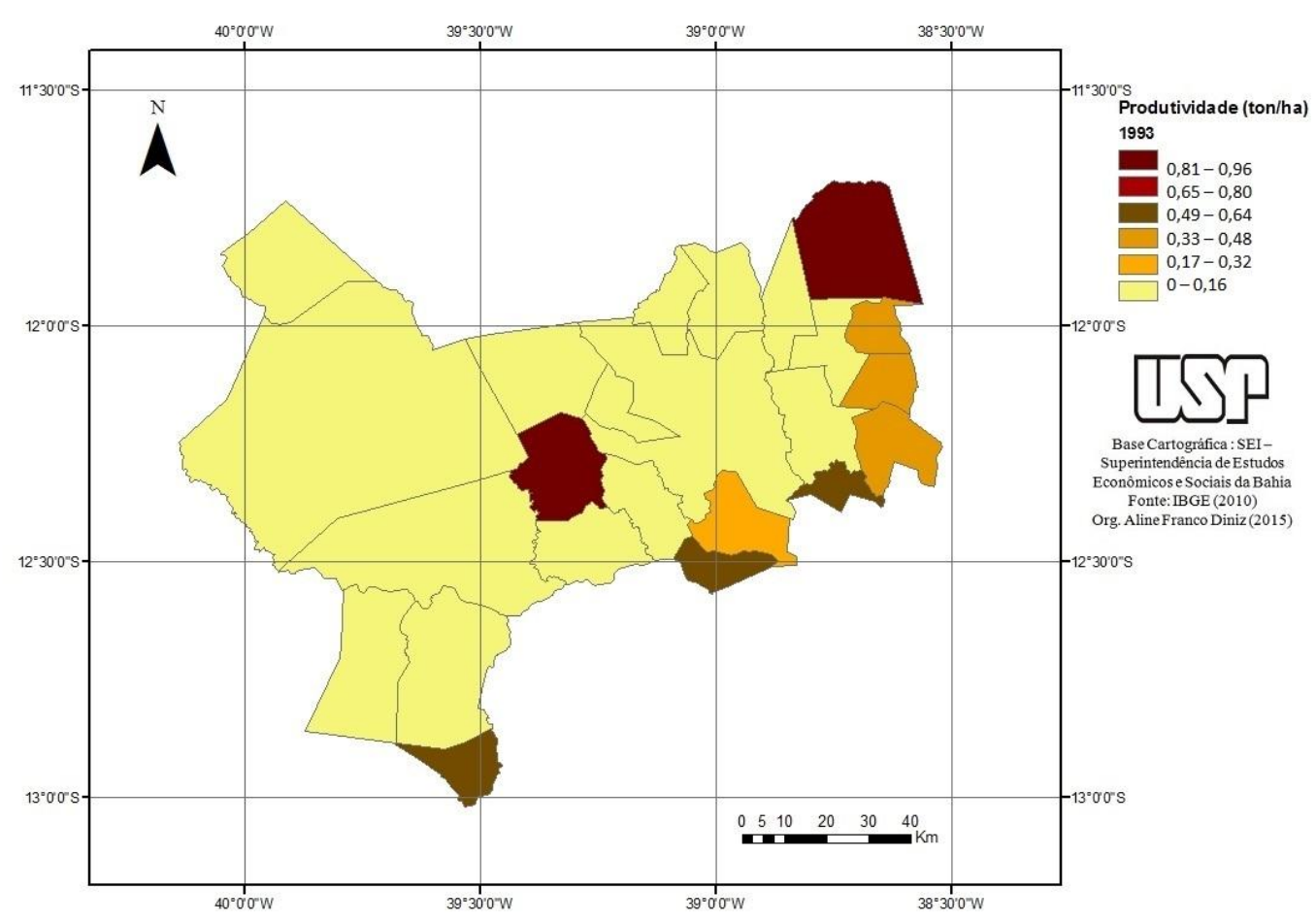

Figura 26: Avaliação temporal e espacial da produtividade da cultura do milho na Microrregião de Feira de Santana (1993).

Fonte: PAM, IBGE (2013)

Elaboração: DINIZ (2015) 


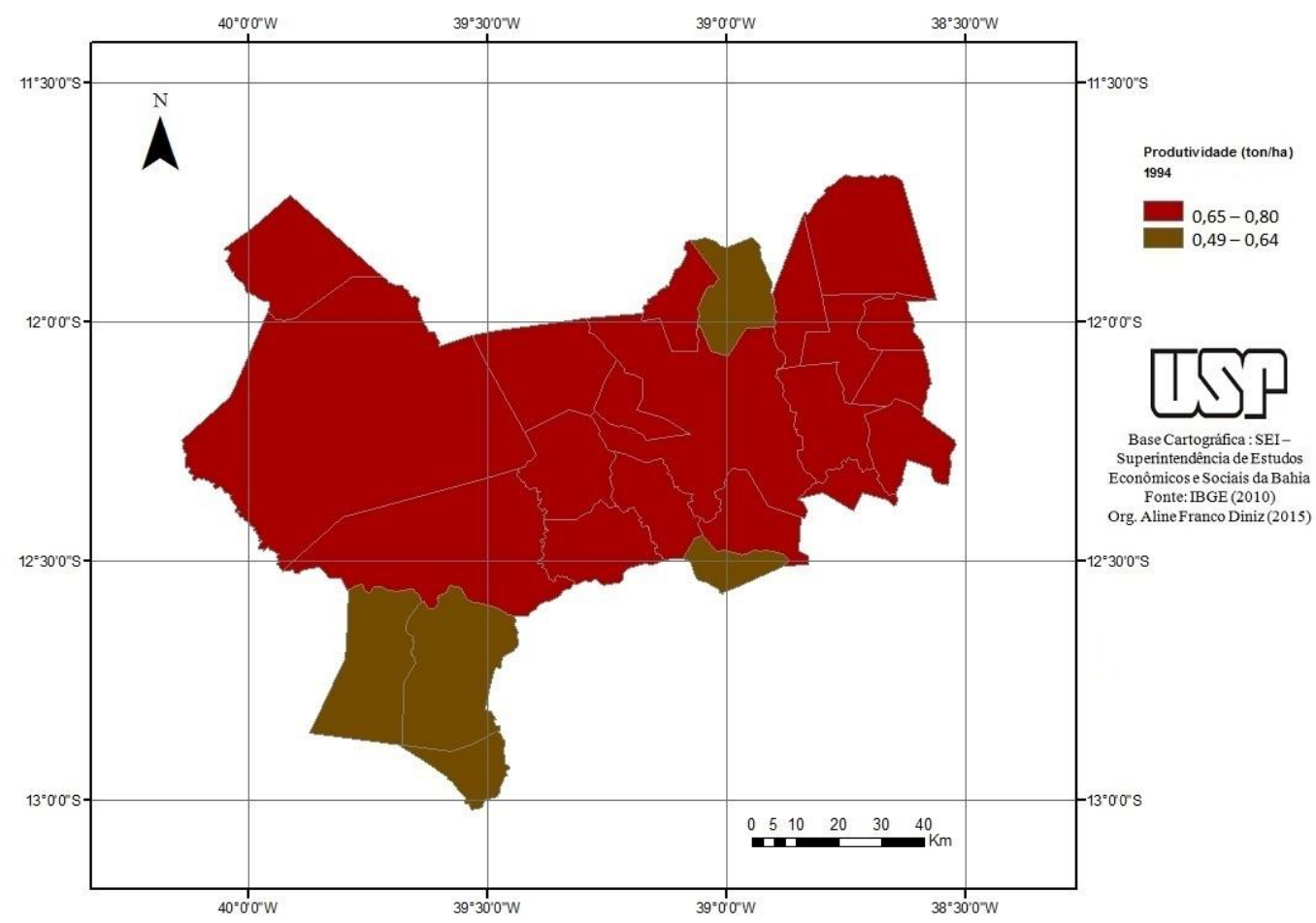

Figura 27: Avaliação temporal e espacial da produtividade da cultura do milho na Microrregião de Feira de Santana (1994).

Fonte: PAM, IBGE (2013)

Elaboração: DINIZ (2015)

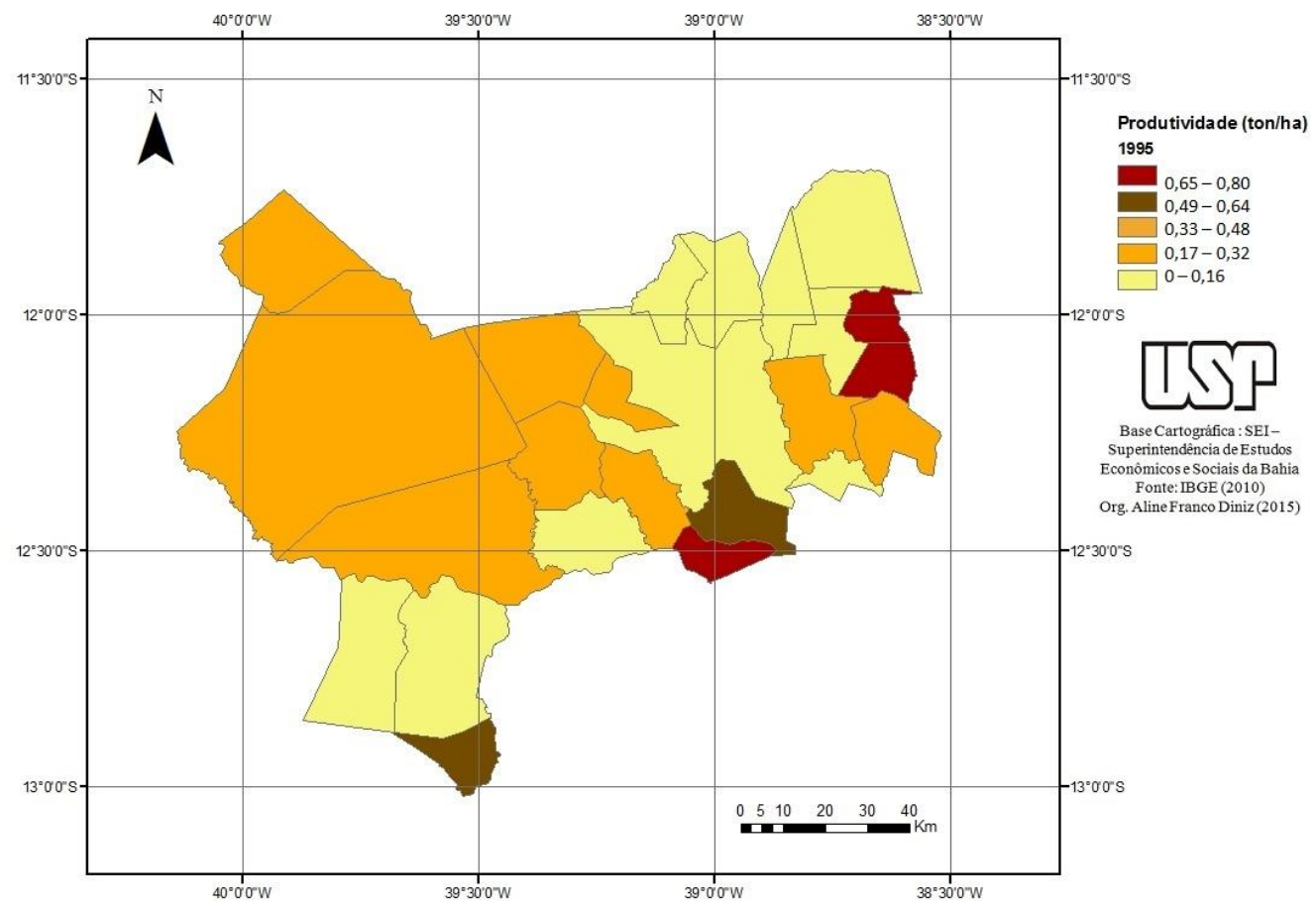

Figura 28: Avaliação temporal e espacial da produtividade da cultura do milho na Microrregião de Feira de Santana (1995).

Fonte: PAM, IBGE (2013)

Elaboração: DINIZ (2015) 


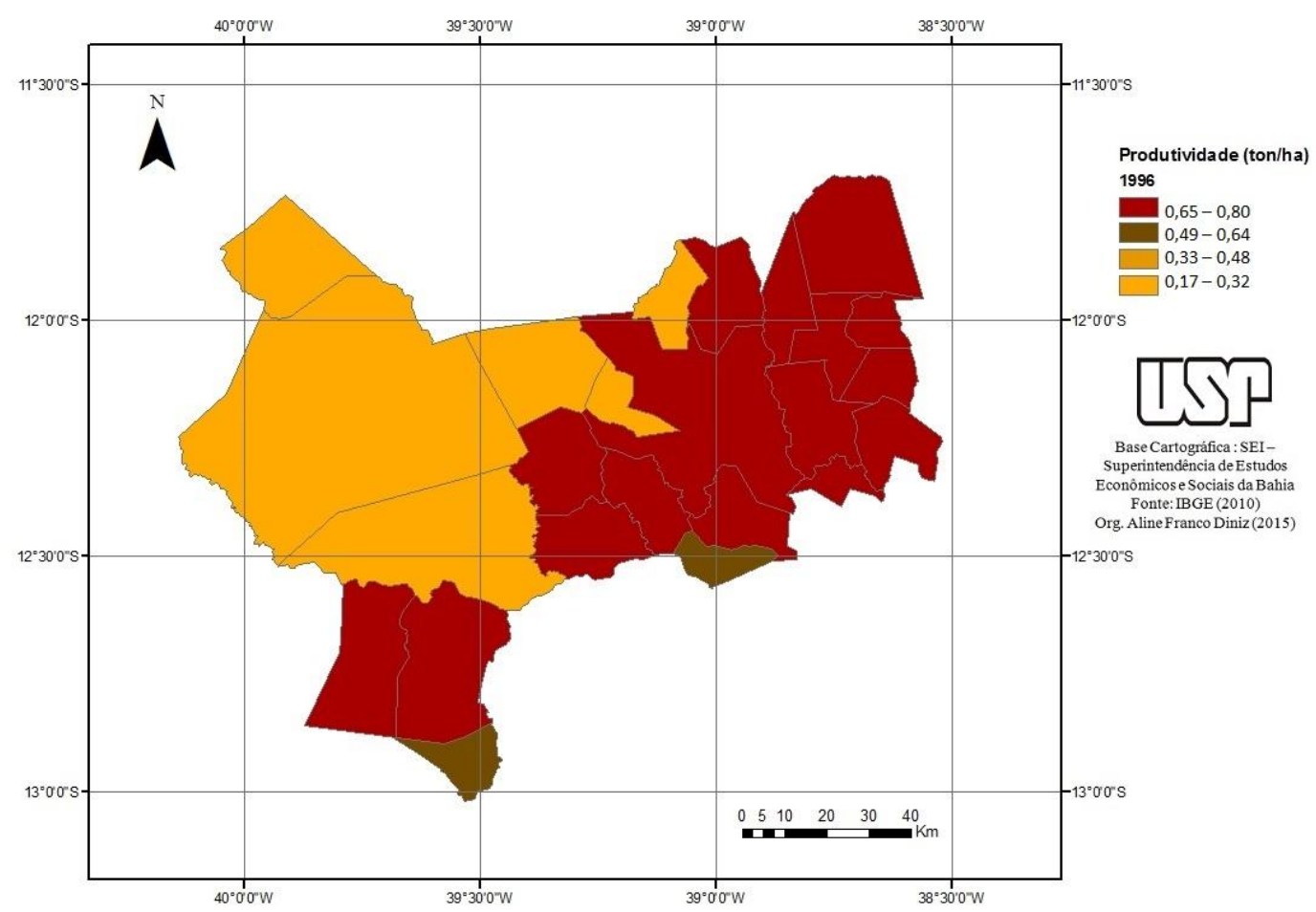

Figura 29: Avaliação temporal e espacial da produtividade da cultura do milho na Microrregião de Feira de Santana (1996).

Fonte: PAM, IBGE (2013)

Elaboração: DINIZ (2015)

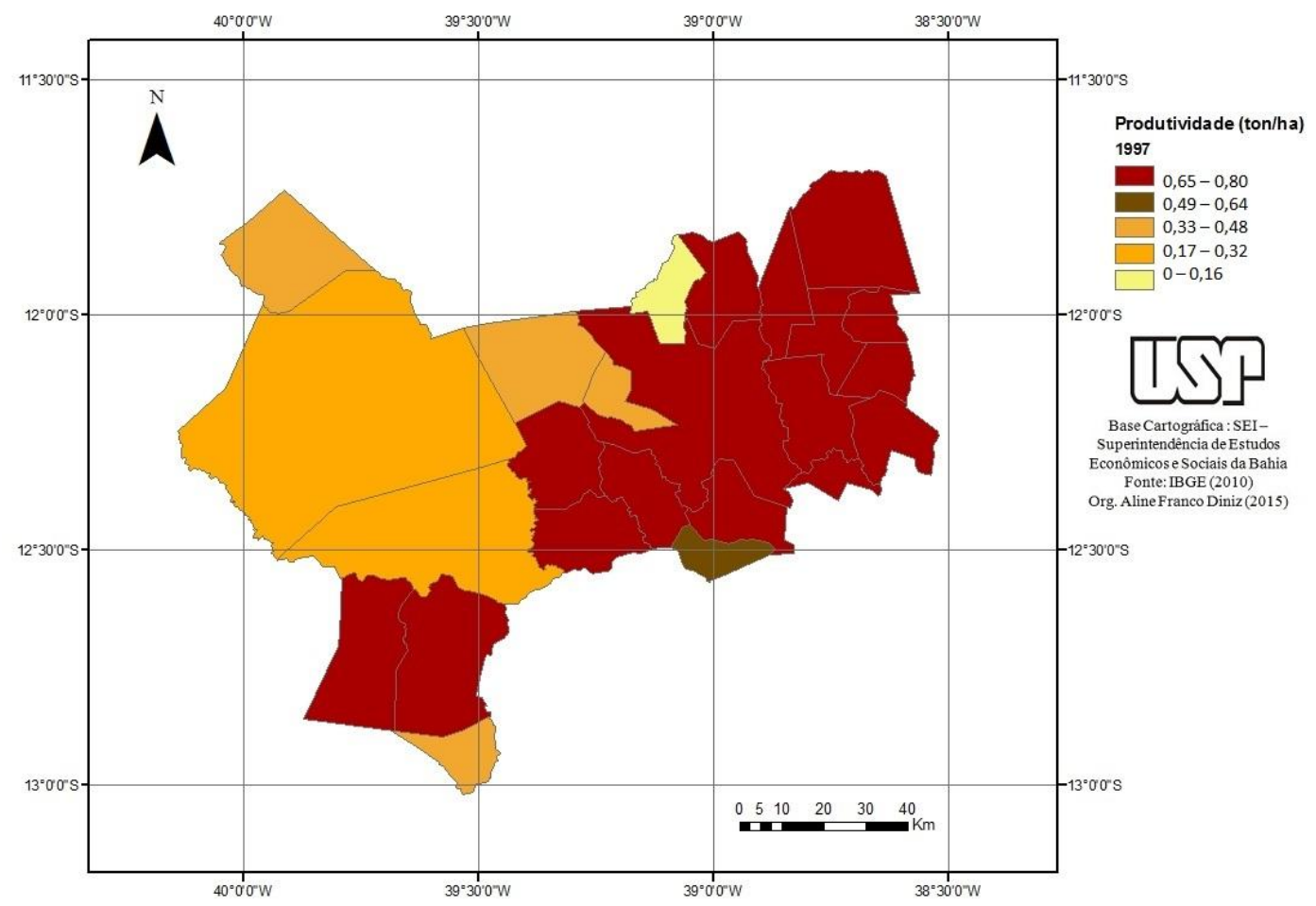

Figura 30: Avaliação temporal e espacial da produtividade da cultura do milho na Microrregião de Feira de Santana (1997).

Fonte: PAM, IBGE (2013)

Elaboração: DINIZ (2015) 


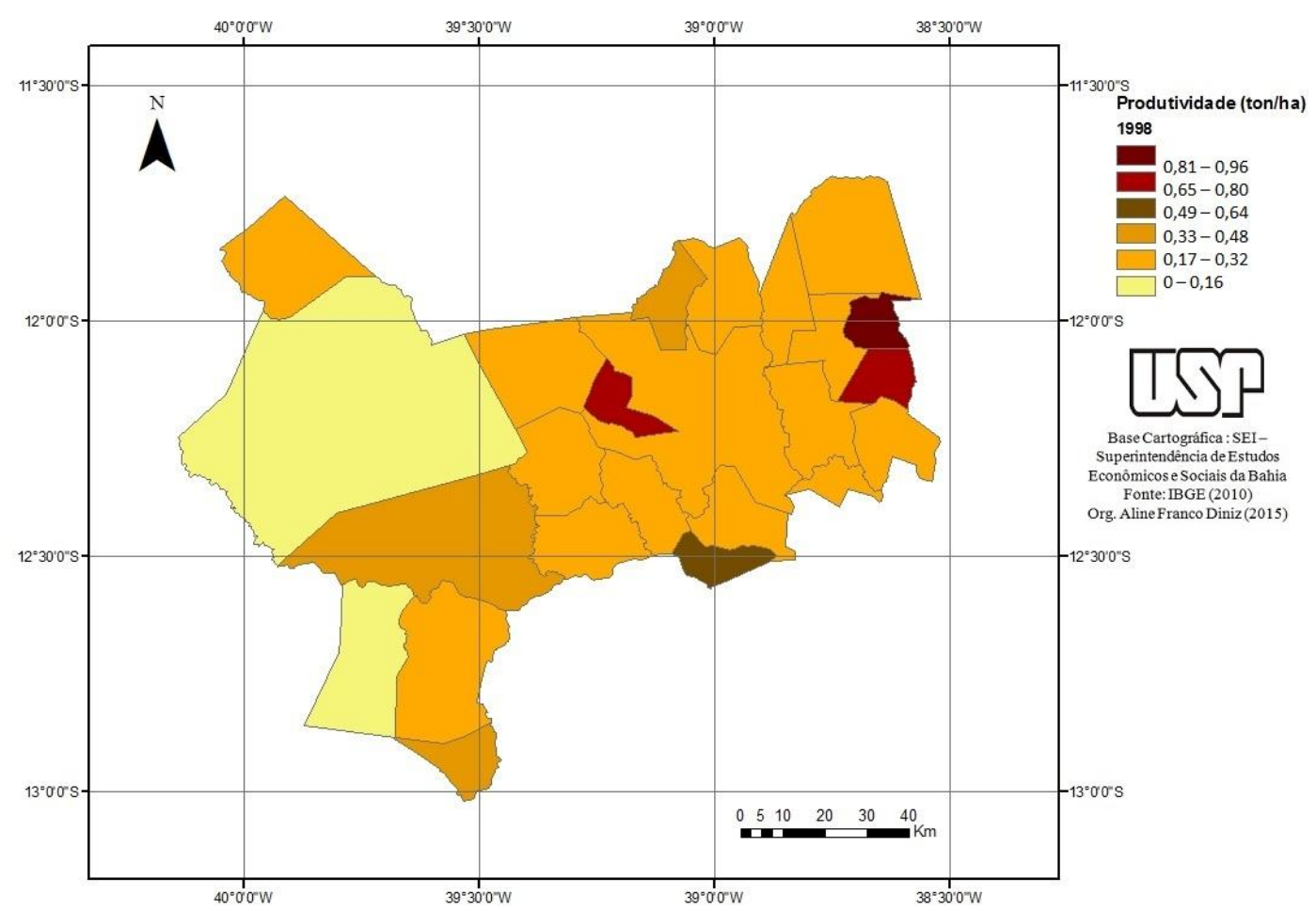

Figura 31: Avaliação temporal e espacial da produtividade da cultura do milho na Microrregião de Feira de Santana (1998).

Fonte: PAM, IBGE (2013)

Elaboração: DINIZ (2015)

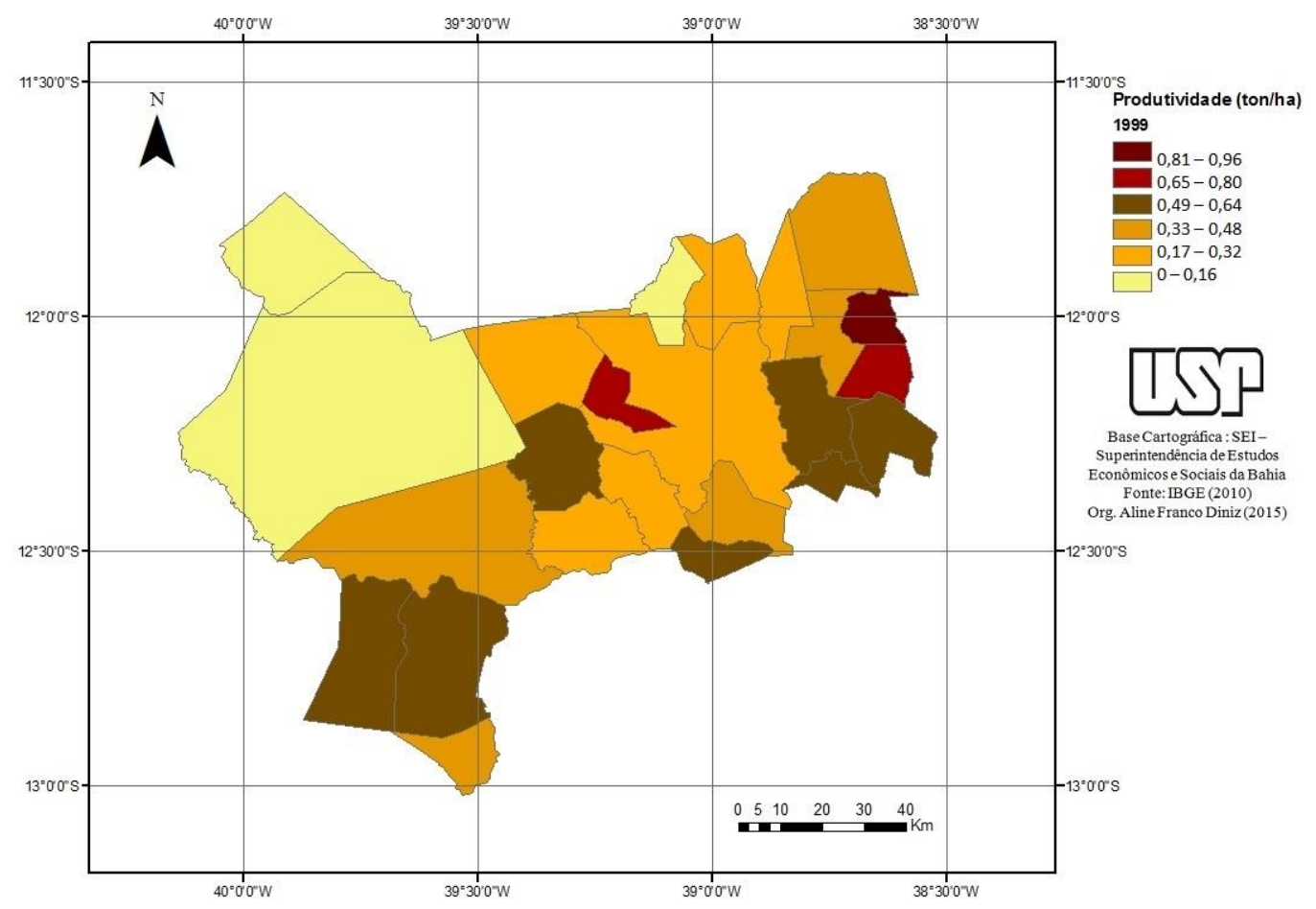

Figura 32: Avaliação temporal e espacial da produtividade da cultura do milho na Microrregião de Feira de Santana (1999).

Fonte: PAM, IBGE (2013)

Elaboração: DINIZ (2015) 


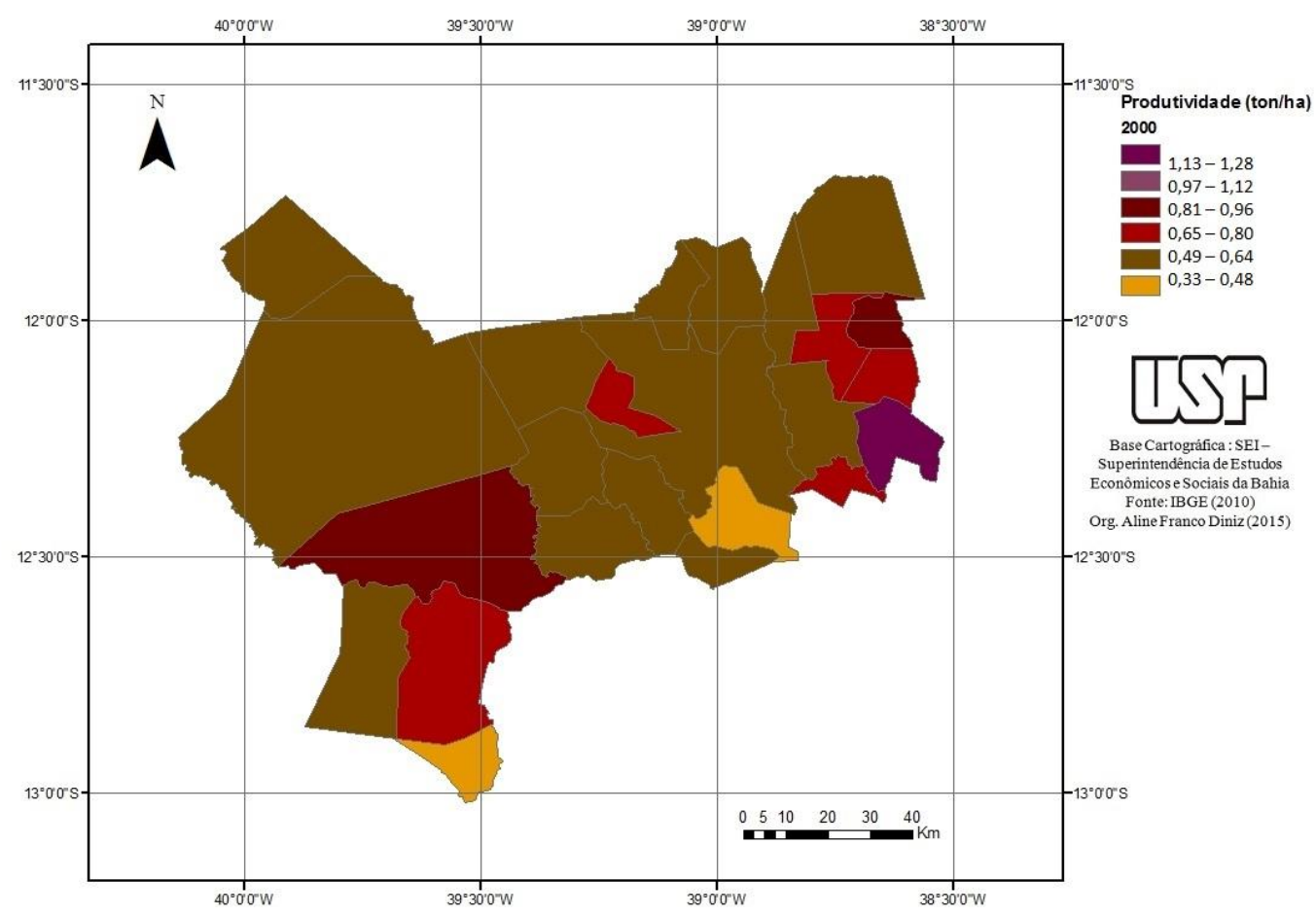

Figura 33: Avaliação temporal e espacial da produtividade da cultura do milho na Microrregião de Feira de Santana (2000).

Fonte: PAM, IBGE (2013)

Elaboração: DINIZ (2015)

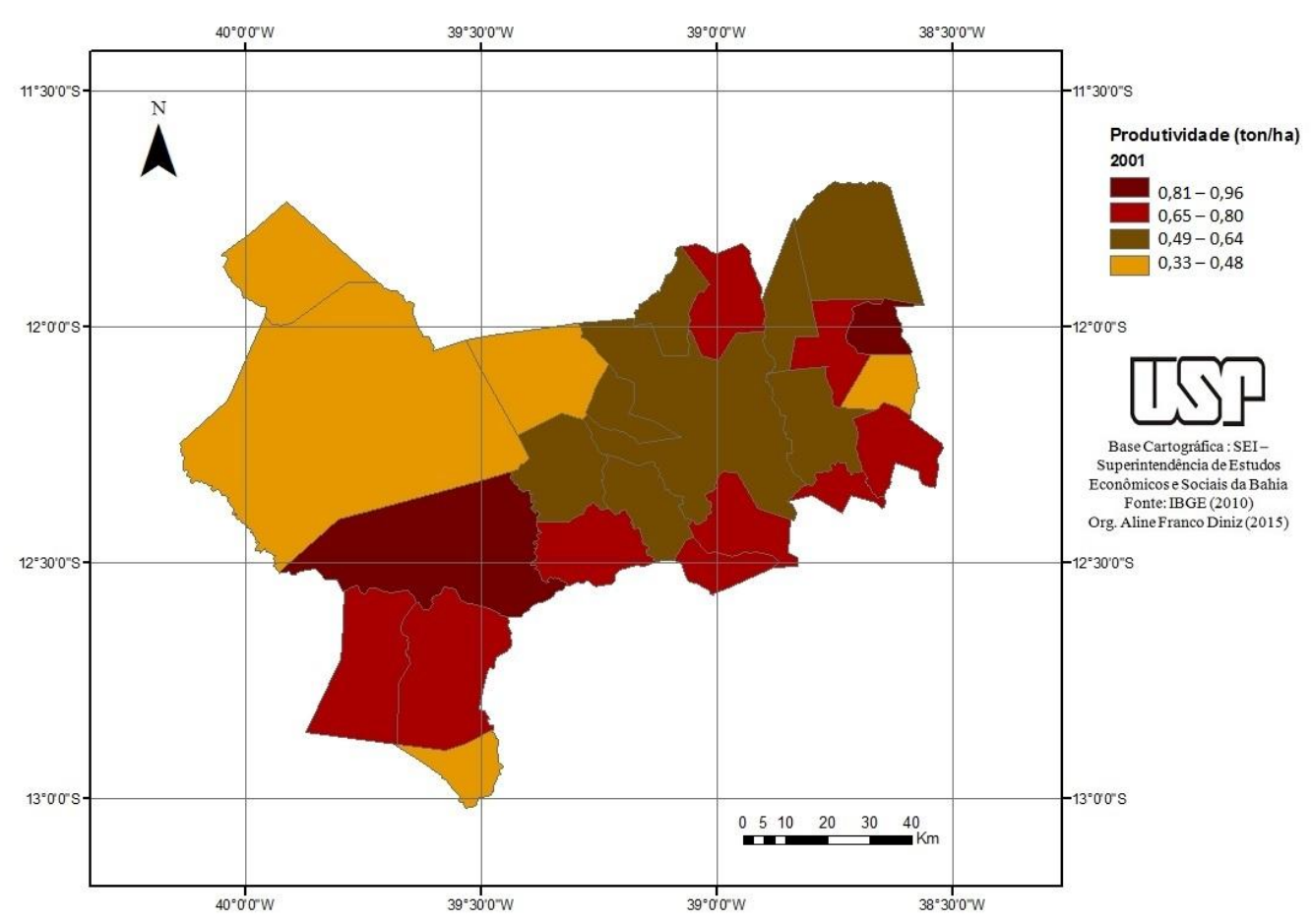

Figura 34: Avaliação temporal e espacial da produtividade da cultura do milho na Microrregião de Feira de Santana (2001).

Fonte: PAM, IBGE (2013)

Elaboração: DINIZ (2015) 


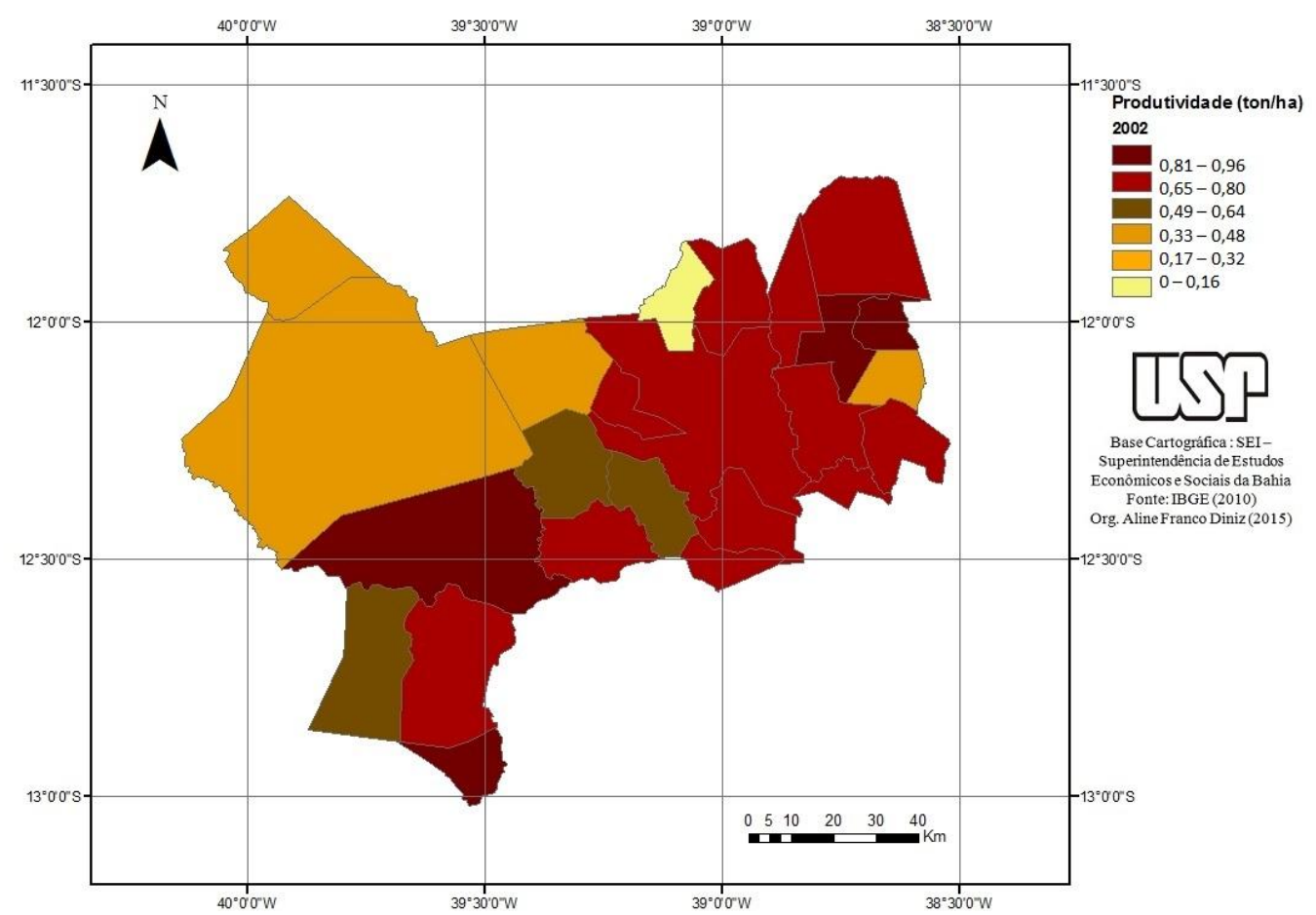

Figura 35: Avaliação temporal e espacial da produtividade da cultura do milho na Microrregião de Feira de Santana (2002).

Fonte: PAM, IBGE (2013)

Elaboração: DINIZ (2015)

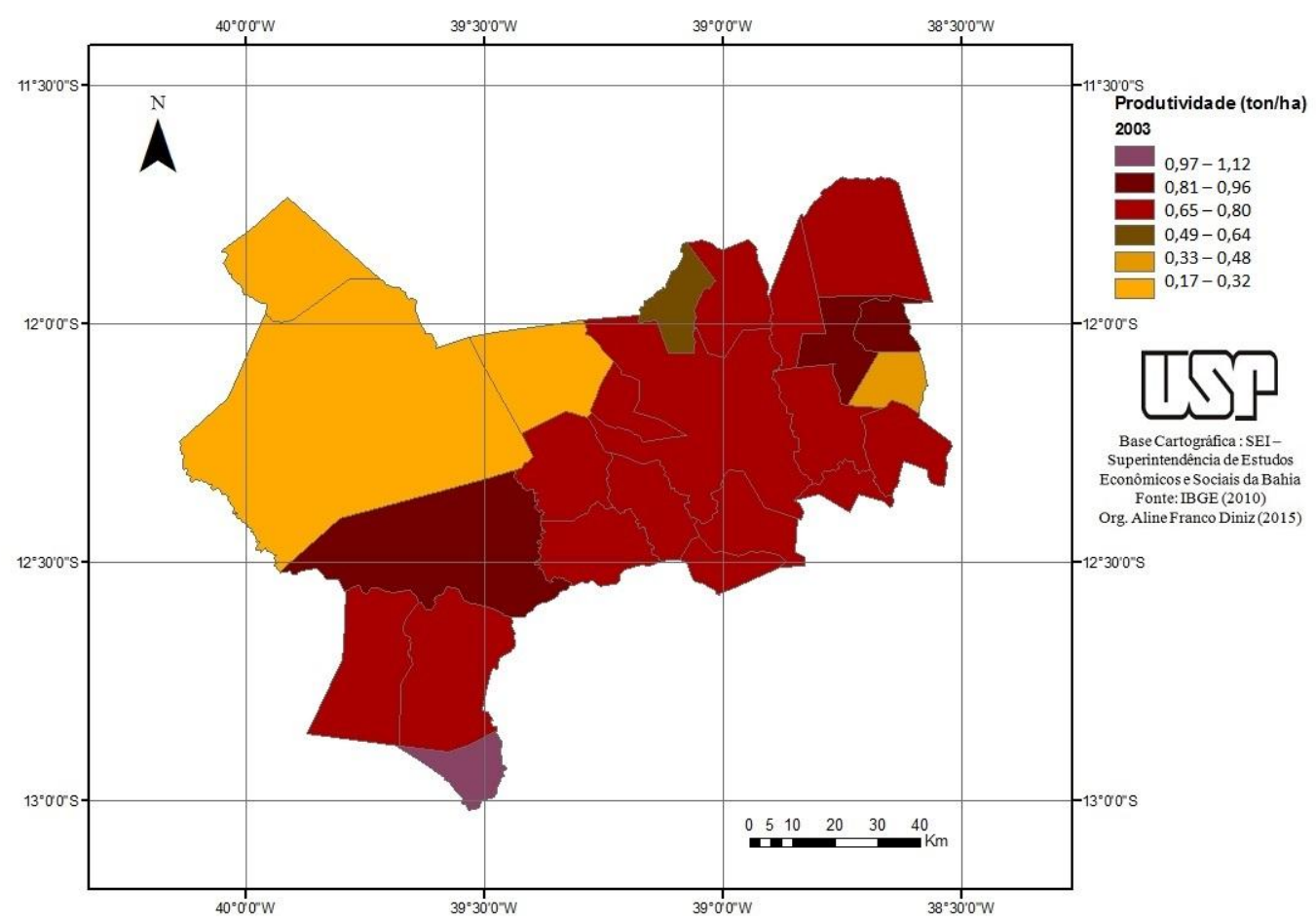

Figura 36: Avaliação temporal e espacial da produtividade da cultura do milho na Microrregião de Feira de Santana (2003).

Fonte: PAM, IBGE (2013)

Elaboração: DINIZ (2015) 


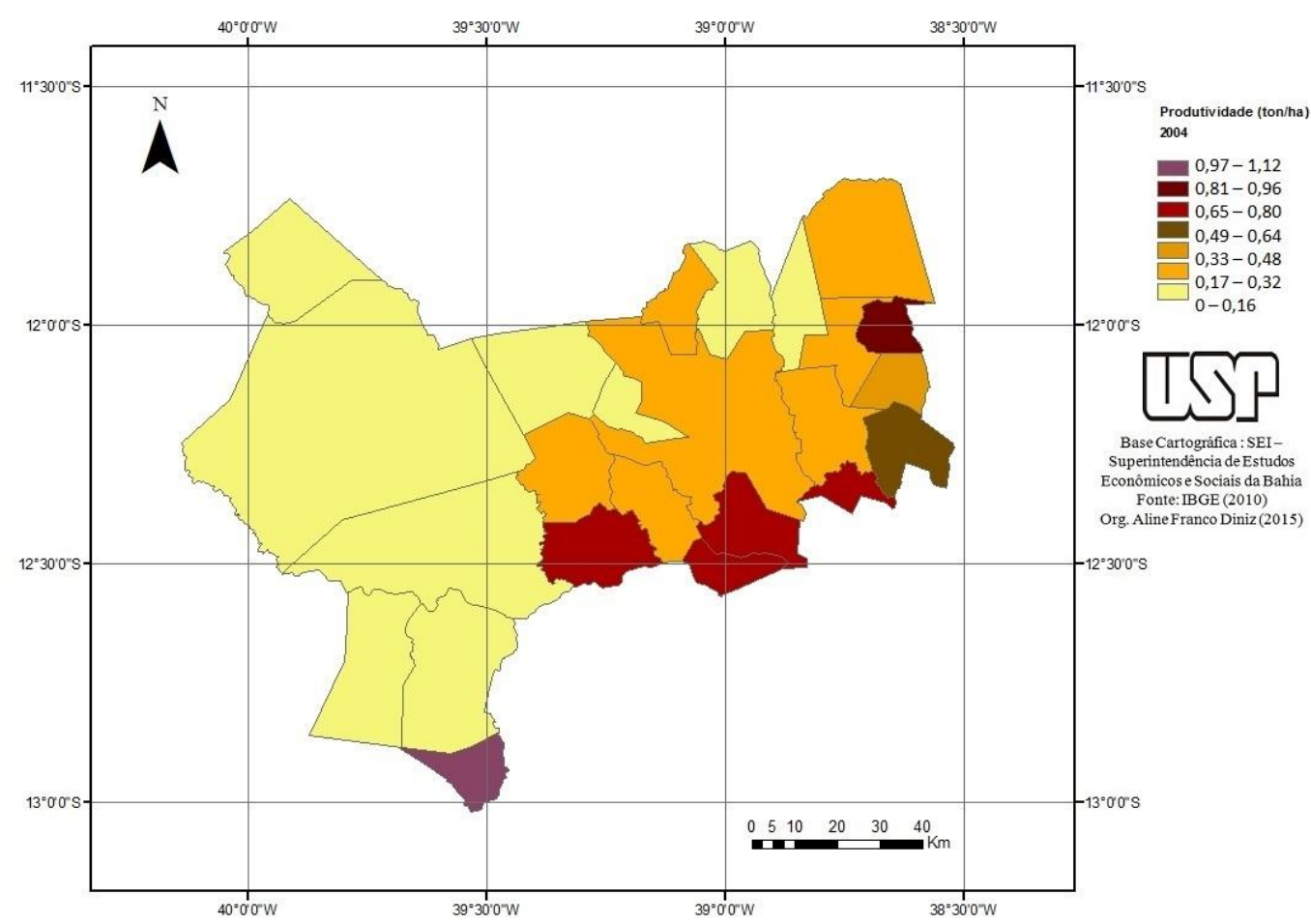

Figura 37: Avaliação temporal e espacial da produtividade da cultura do milho na Microrregião de Feira de Santana (2004).

Fonte: PAM, IBGE (2013)

Elaboração: DINIZ (2015)

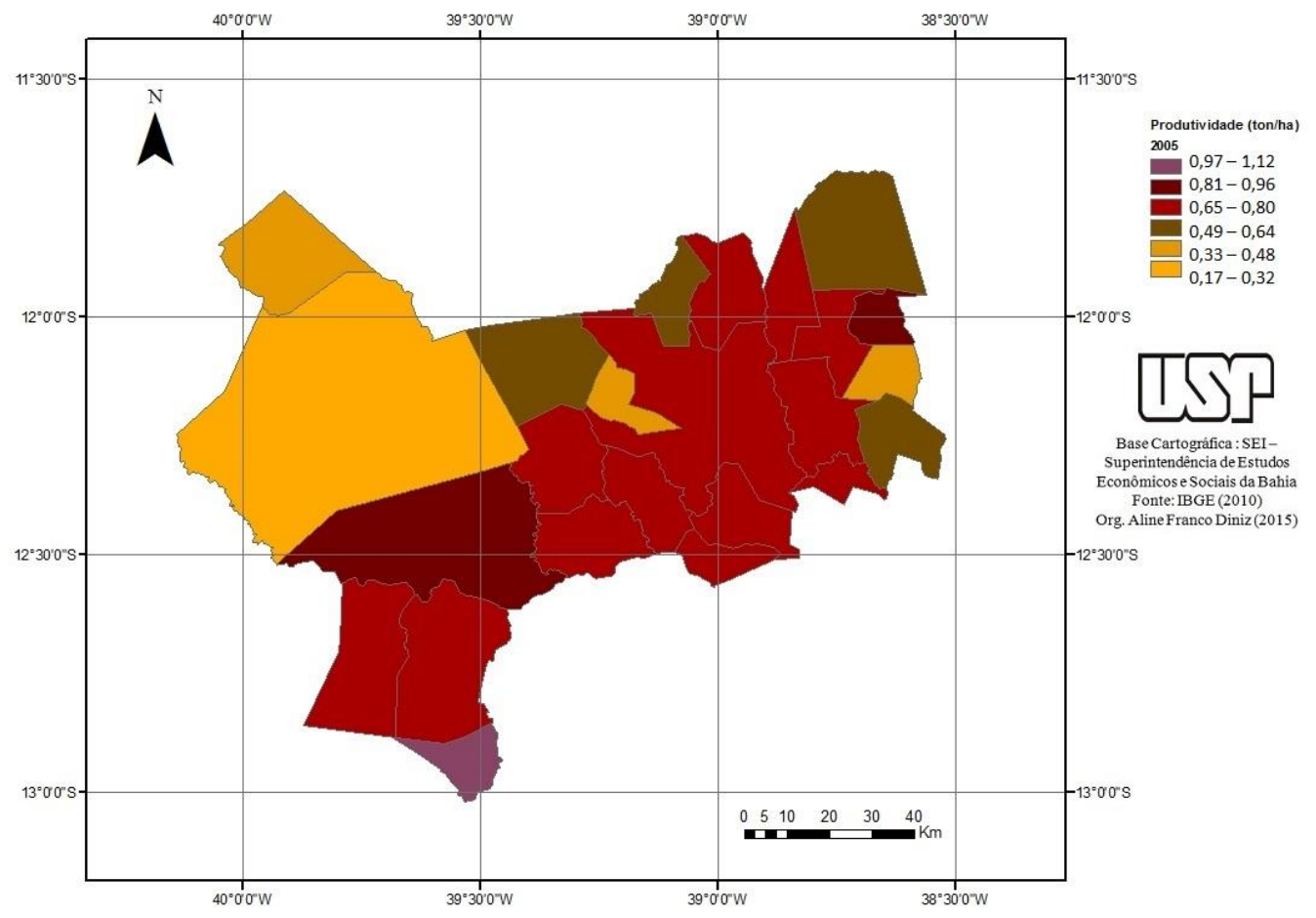

Figura 38: Avaliação temporal e espacial da produtividade da cultura do milho na Microrregião de Feira de Santana (2005).

Fonte: PAM, IBGE (2013)

Elaboração: DINIZ (2015) 


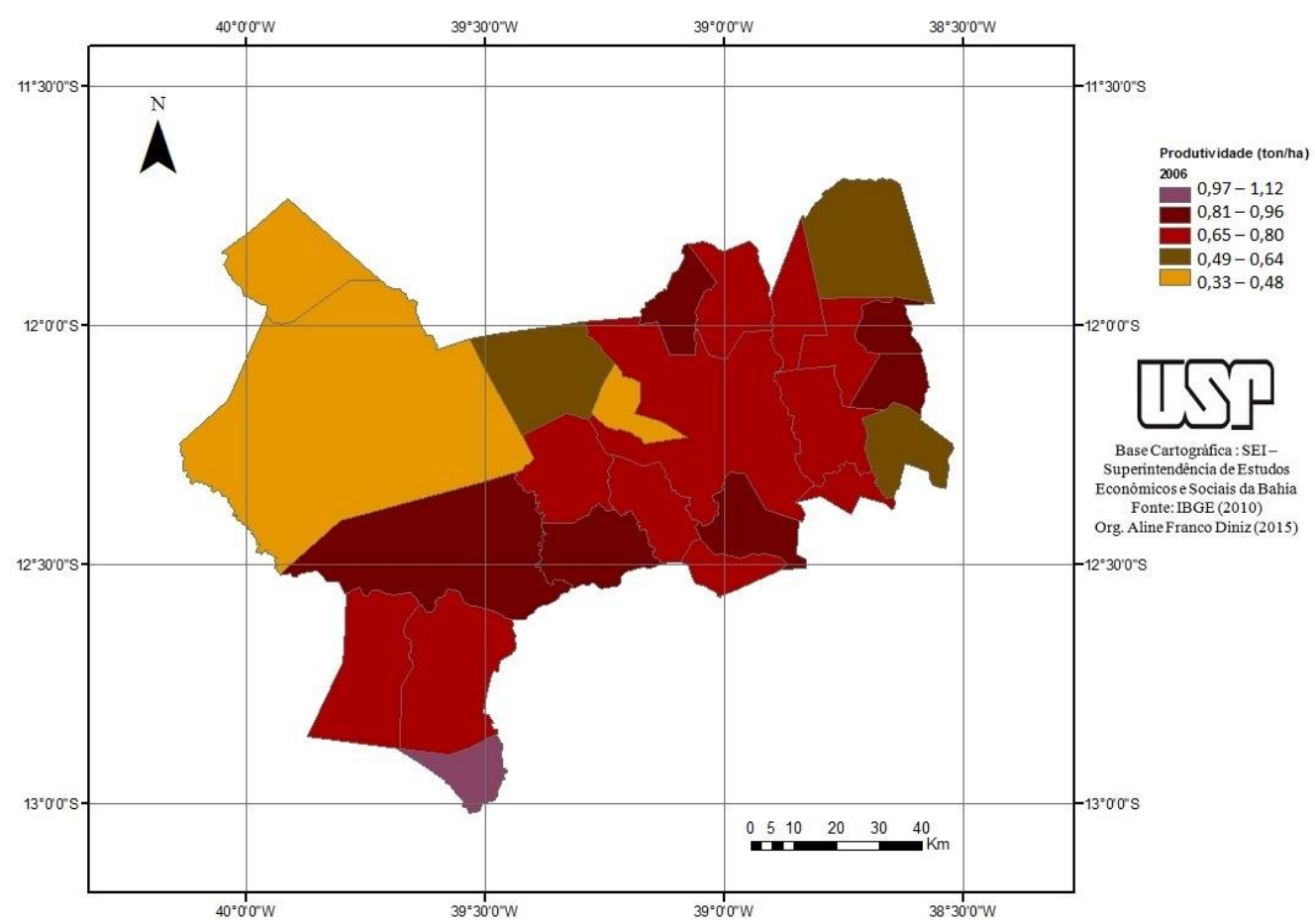

Figura 39: Avaliação temporal e espacial da produtividade da cultura do milho na Microrregião de Feira de Santana (2006).

Fonte: PAM, IBGE (2013)

Elaboração: DINIZ (2015)

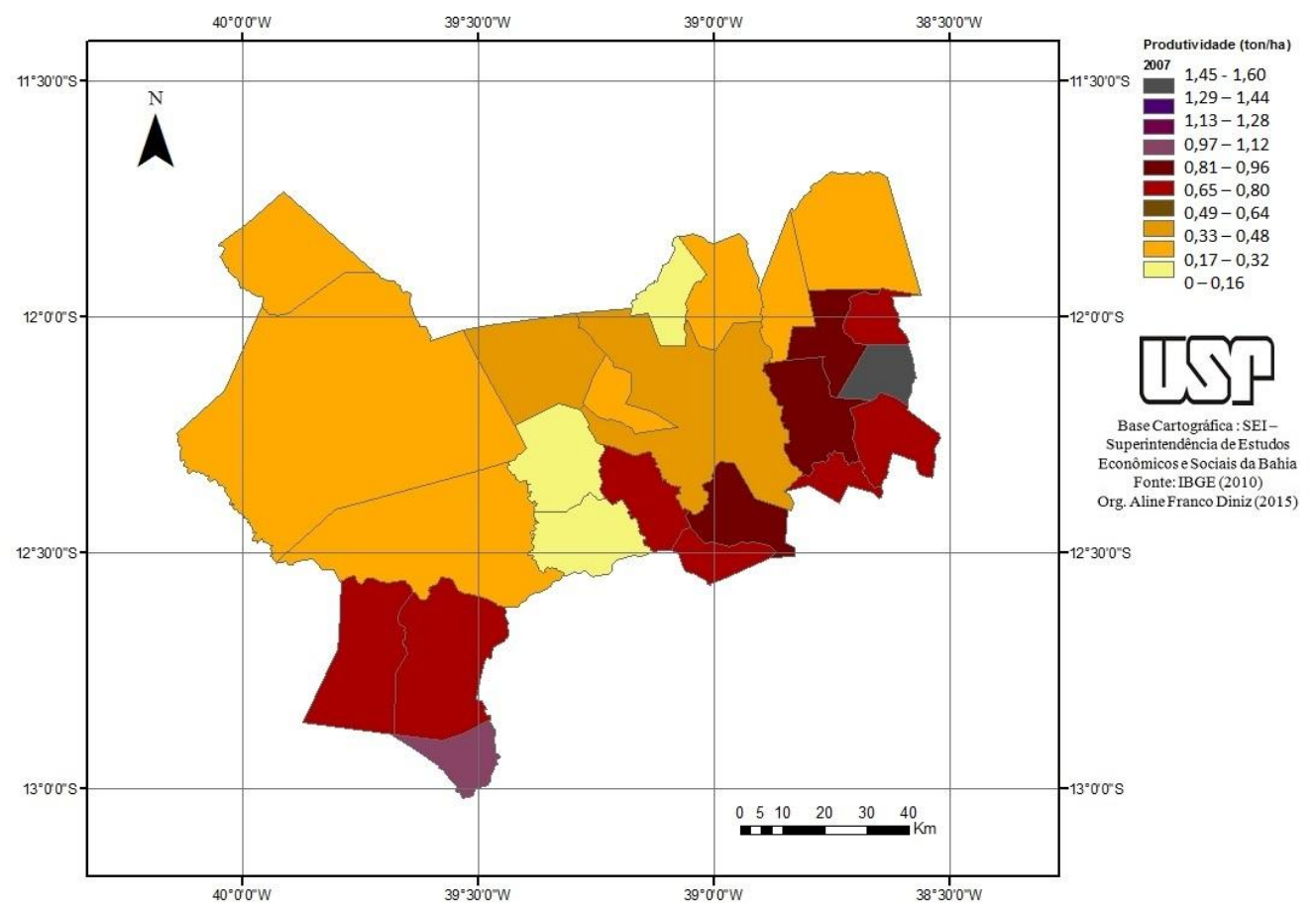

Figura 40: Avaliação temporal e espacial da produtividade da cultura do milho na Microrregião de Feira de Santana (2007).

Fonte: PAM, IBGE (2013)

Elaboração: DINIZ (2015) 


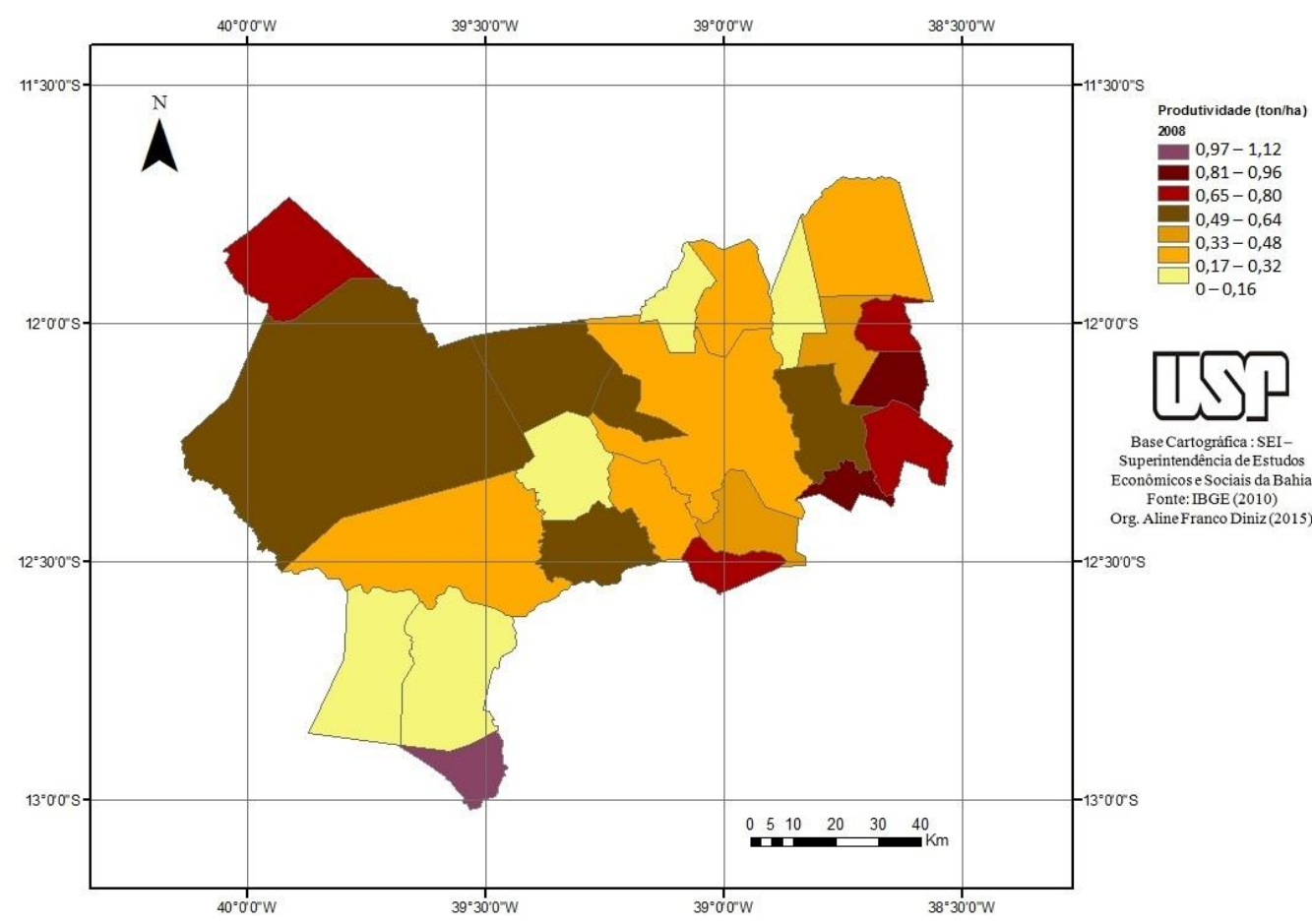

Figura 41: Avaliação temporal e espacial da produtividade da cultura do milho na Microrregião de Feira de Santana (2008).

Fonte: PAM, IBGE (2013)

Elaboração: DINIZ (2015)

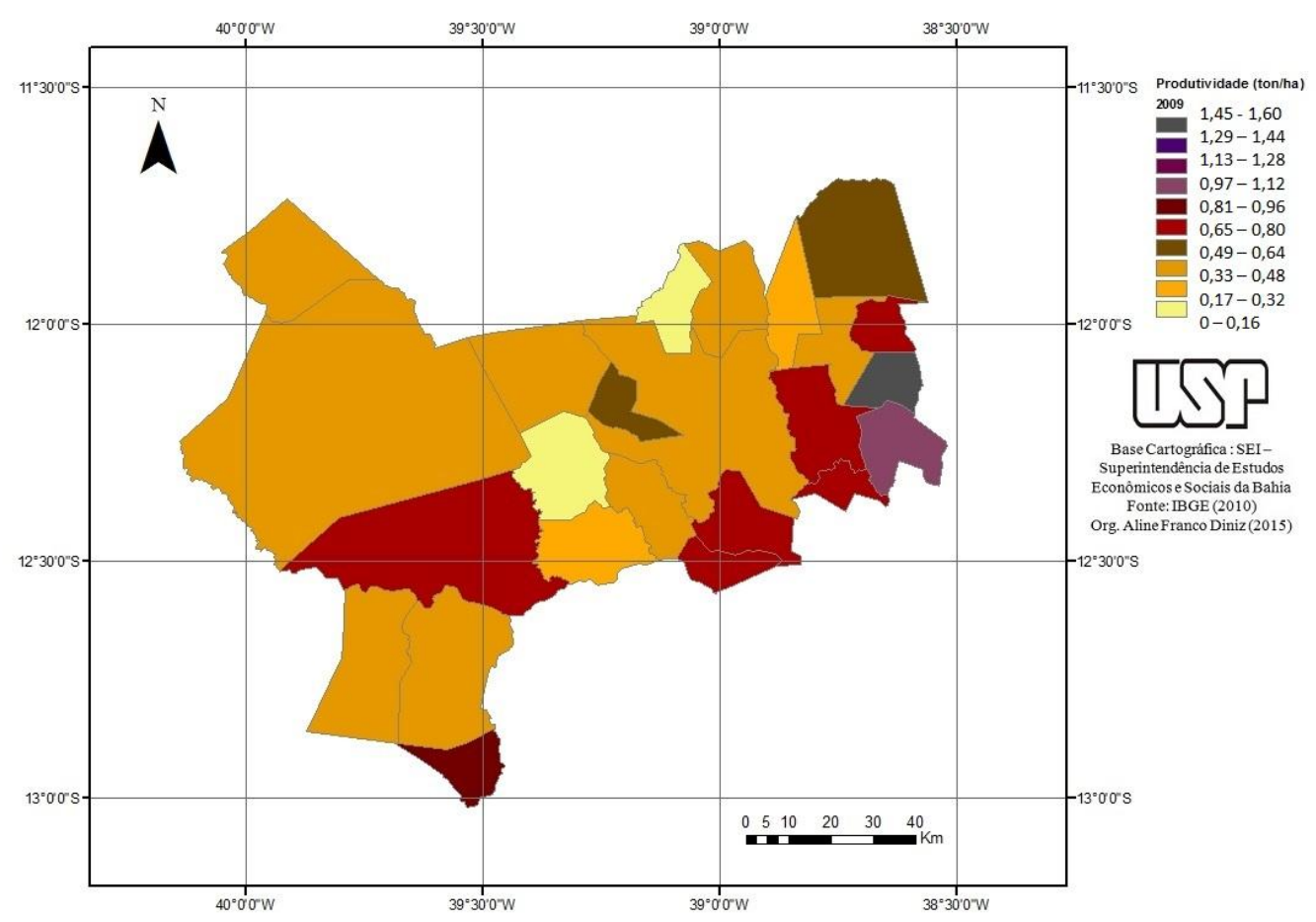

Figura 42: Avaliação temporal e espacial da produtividade da cultura do milho na Microrregião de Feira de Santana (2009).

Fonte: PAM, IBGE (2013)

Elaboração: DINIZ (2015) 


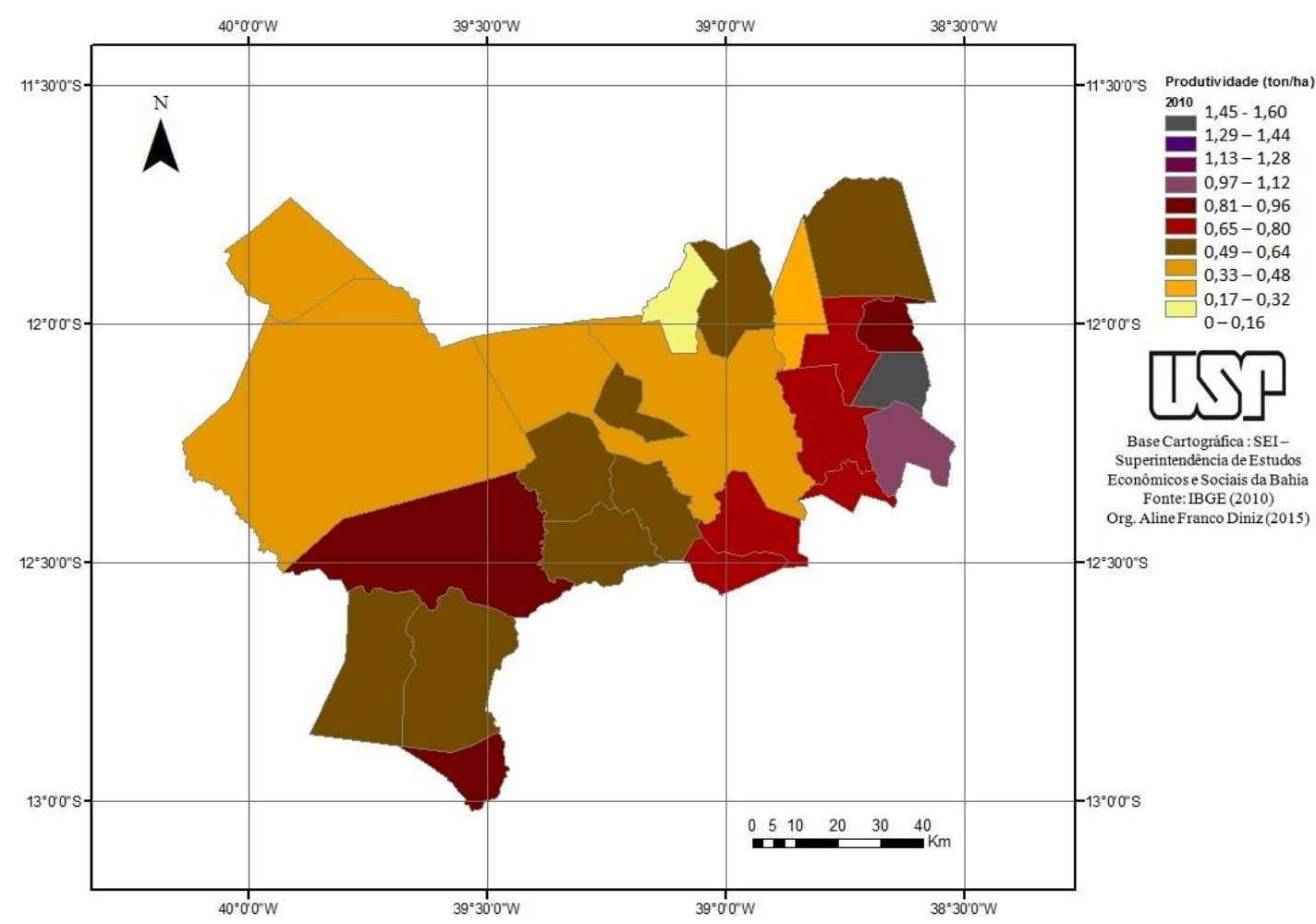

Figura 43: Avaliação temporal e espacial da produtividade da cultura do milho na Microrregião de Feira de Santana (2010).

Fonte: PAM, IBGE (2013)

Elaboração: DINIZ (2015)

É possível observar nas Figuras 23 a $\mathbf{4 3}$ que as maiores produtividade da cultura do milho são nos municípios de Conceição da Feira, Coração de Maria, Elísio Medrado, Irará, Ouriçangas, Pedrão, São Gonçalo dos Campos, Teodoro Sampaio dentro da série histórica da microrregião em estudo.

No contexto nacional, foi possível notar que os estados de Mato Grosso e Paraná, são os maiores produtores de milho do país (Figura 44), responsável por $65 \%$ da produção do milho. A Bahia com $3 \%$ da produção do milho no contexto nacional. Na Figura 45 verifica-se que $90 \%$ da produção de milho em grão no Brasil (2009/2010) foi produzida em nove estados, sendo apenas Bahia o único estado fora da região Centro-Sul. 


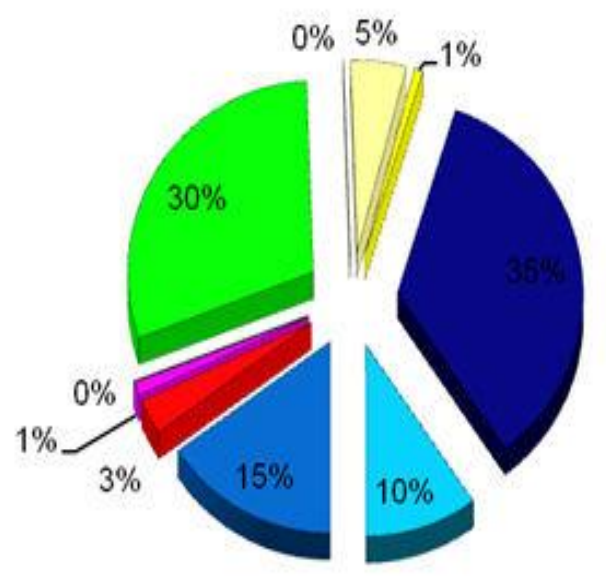

Figura 44: Ranking da produção estadual do milho no Brasil em 2010 em milhões de toneladas.

Fonte: CONAB (2010)

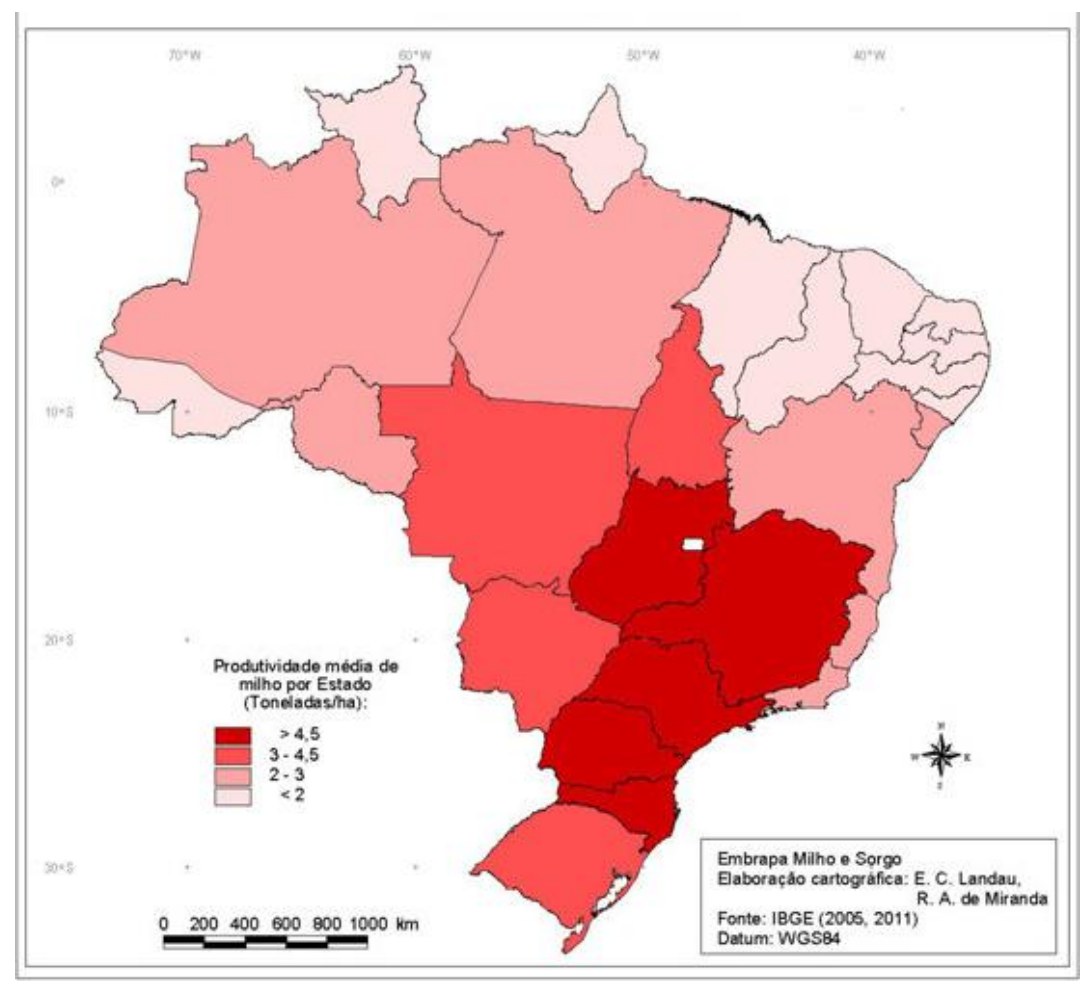

Figura 45: Distribuição da produtividade do milho no Brasil no período de 2007 a 2010. Fonte: CONAB (2010)

Ao analisar a produtividade do Nordeste, observamos que ela é historicamente muito baixa, sendo inferior a $1.000 \mathrm{~kg} / \mathrm{ha}$ até o início dos anos 2000. A partir do início desta década, os níveis de produtividade aumentaram 
até alcançar a média de $1.300 \mathrm{~kg} / \mathrm{ha}$ nos últimos anos; isto principalmente pelo aumento da produção de milho nas regiões oeste da Bahia, Alto do Rio Parnaíba no Piauí e sul do Maranhão. Apesar dos melhores níveis de produtividade nestas regiões, ainda os índices do Nordeste ficam bem abaixo da média brasileira.

As regiões que têm melhores produtividades são aquelas que produzem comercialmente, com condições edafoclimáticas melhores, com uso de tecnologias modernas, com cultivares adaptadas às regiões, com possibilidade de maior mecanização e mercado bem definido para o produto. Por outro lado, as regiões com menores produtividades são aquelas onde a produção de milho é feita de forma quase artesanal, com sementes muitas vezes não adaptadas à região, com baixo nível de uso de insumos modernos e para consumo próprio.

Na região oeste da Bahia, a mais tecnificada do estado, onde se tem o cultivo em espaçamento adensado, correção e fertilização de solo, com uso de sementes híbridas, manejo de pragas e doenças. A região citada é responsável por $66 \%$ de todo o milho produzido no estado e abastece tanto as granjas de aves e suínos, como a indústria alimentícia do Nordeste do país. A produção alcançou 1,5 milhão de toneladas. Nas outras regiões do estado, onde são produzidos pelos agricultores familiares, muitas vezes temos a produção do milho em consórcio com o feijão, à mandioca ou outra cultura.

A Figura 46 refere-se à área plantada do cultivo do milho nos municípios em estudo: Teodoro Sampaio, Feira de Santana e Rafael Jambeiro. É possível perceber que os anos de 1996, 1997 e 1998 tiverem maiores valores de área plantada em Teodoro Sampaio. Em Feira de Santana os maiores valores de área plantada foram nos anos de 2005, 2006 e 2010. No município de Rafael 
Jambeiro os maiores valores de área plantada foram nos anos 2000, 2001 e 2004.

Na Figura 46 os menores valores de área plantada no município de Teodoro Sampaio foram nos anos de 1993, 2000 e 2008. Em Feira de Santana os menores valores de área plantada foram nos anos de 1992, 1993 e 2004. No município de Rafael Jambeiro os menores valores de área plantada foram nos anos 1990, 1999 e 2002.

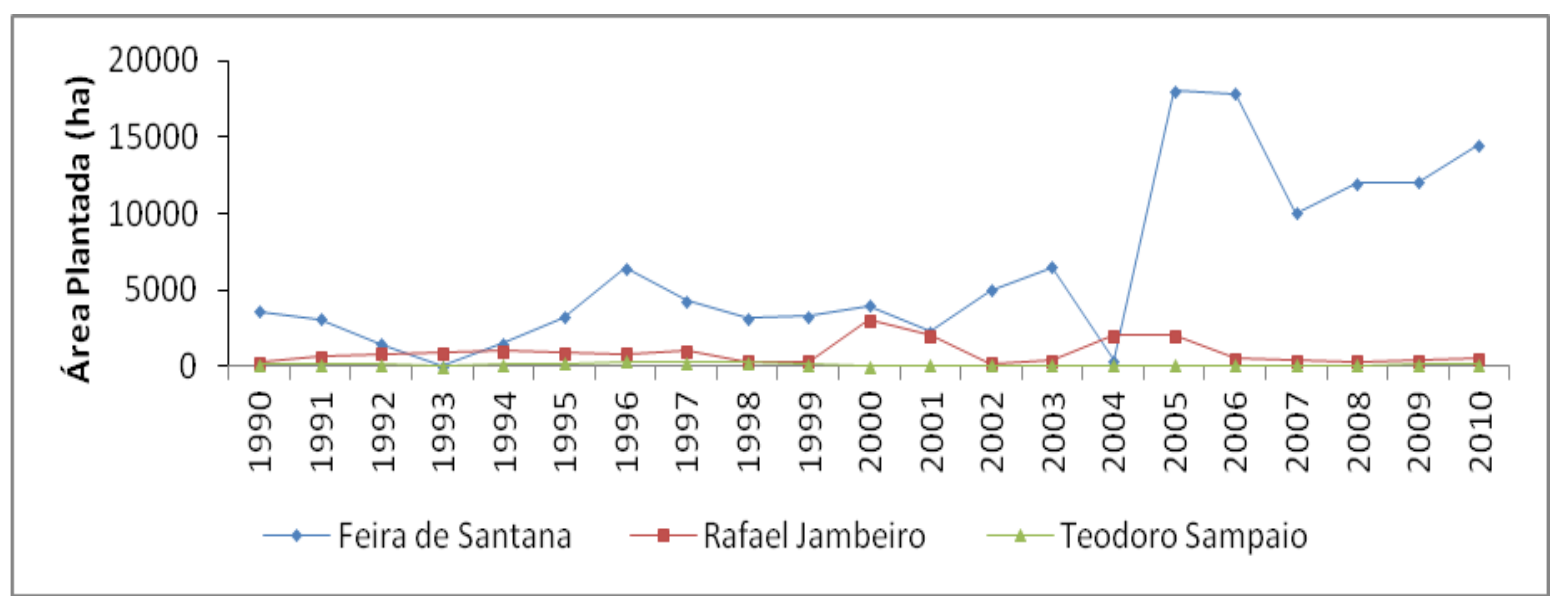

Figura 46: Dados da área plantada (ha) do cultivo do milho nos municípios de Feira de Santana, Rafael Jambeiro e Teodoro Sampaio no período de 1990 a 2010.

Fonte: PAM, IBGE (2013)

Elaboração: DINIZ (2015)

A Figura 47 refere-se à produção do cultivo do milho nos municípios em estudo, é possível perceber que os anos de 1996, 1997 e 2009 tiverem maiores valores de produção em Teodoro Sampaio. Em Feira de Santana os maiores valores de produção foram nos anos de 2005, 2006 e 2009, e no município de Rafael Jambeiro os maiores valores de produção foram nos anos 2000, 2001 e 2005.

Na Figura 47 os menores valores de produção no município de Teodoro Sampaio foram nos anos de 1990, 1993 e 2008. Em Feira de Santana os menores valores de produção foram nos anos de 1993, 1995 e 2004. No 
município de Rafael Jambeiro os menores valores de produção foram nos anos 1992, 2004 e 2008.

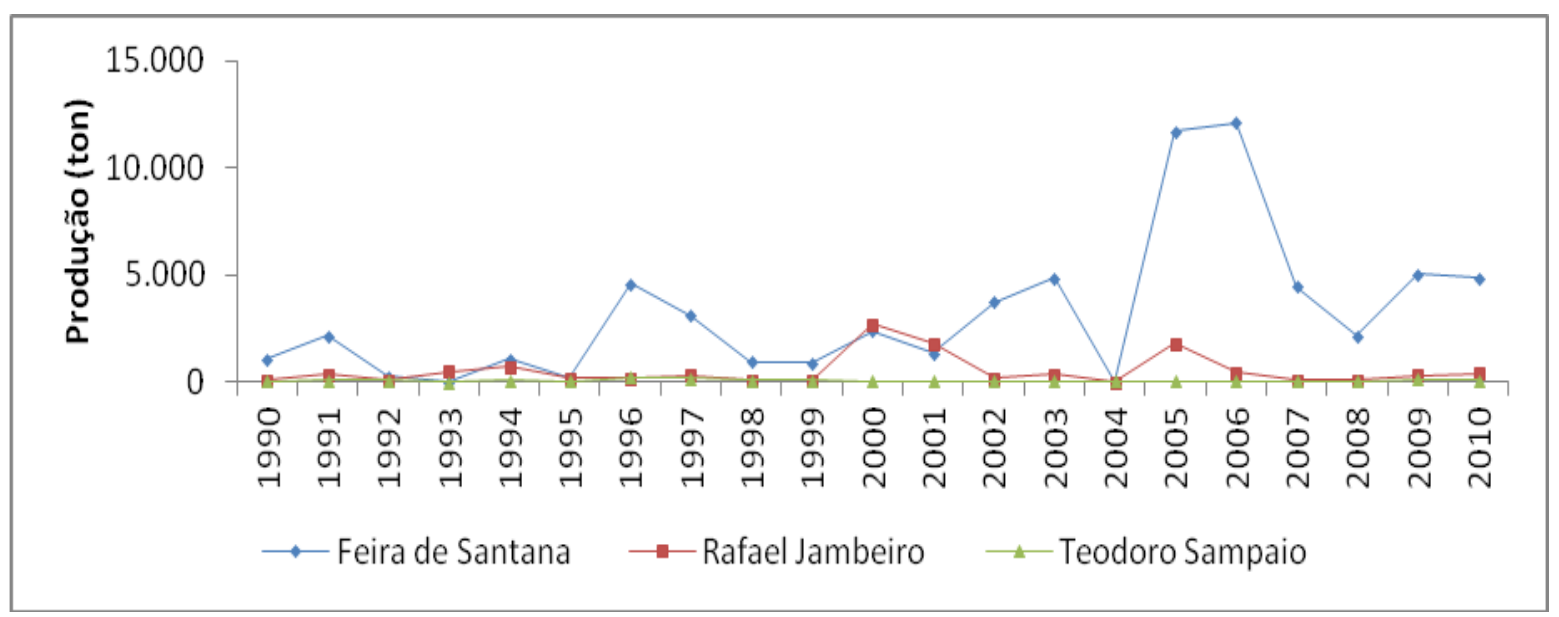

Figura 47: Dados da produção (ton) do cultivo do milho nos municípios de Feira de Santana, Rafael Jambeiro e Teodoro Sampaio no período de 1990 a 2010.

Fonte: PAM, IBGE (2013)

Elaboração: DINIZ (2015)

A Figura 48 refere-se à produtividade do cultivo do milho nos municípios em estudo, é possível perceber que os anos de 2000, 2009 e 2010 tiverem maiores valores de produtividade em Teodoro Sampaio. Em Feira de Santana os maiores valores de produtividade foram nos anos de 1994, 2000 e 2003, e no município de Rafael Jambeiro os maiores valores de produtividade foram nos anos 2000, 2001 e 2002.

Na Figura 48 os menores valores de produtividade no município de Teodoro Sampaio foram nos anos de 1990, 1995 e 1998. Em Feira de Santana os menores valores de produtividade foram nos anos de 1993, 1995 e 2004. No município de Rafael Jambeiro os menores valores de produtividade foram nos anos 1992, 1993 e 2004. 


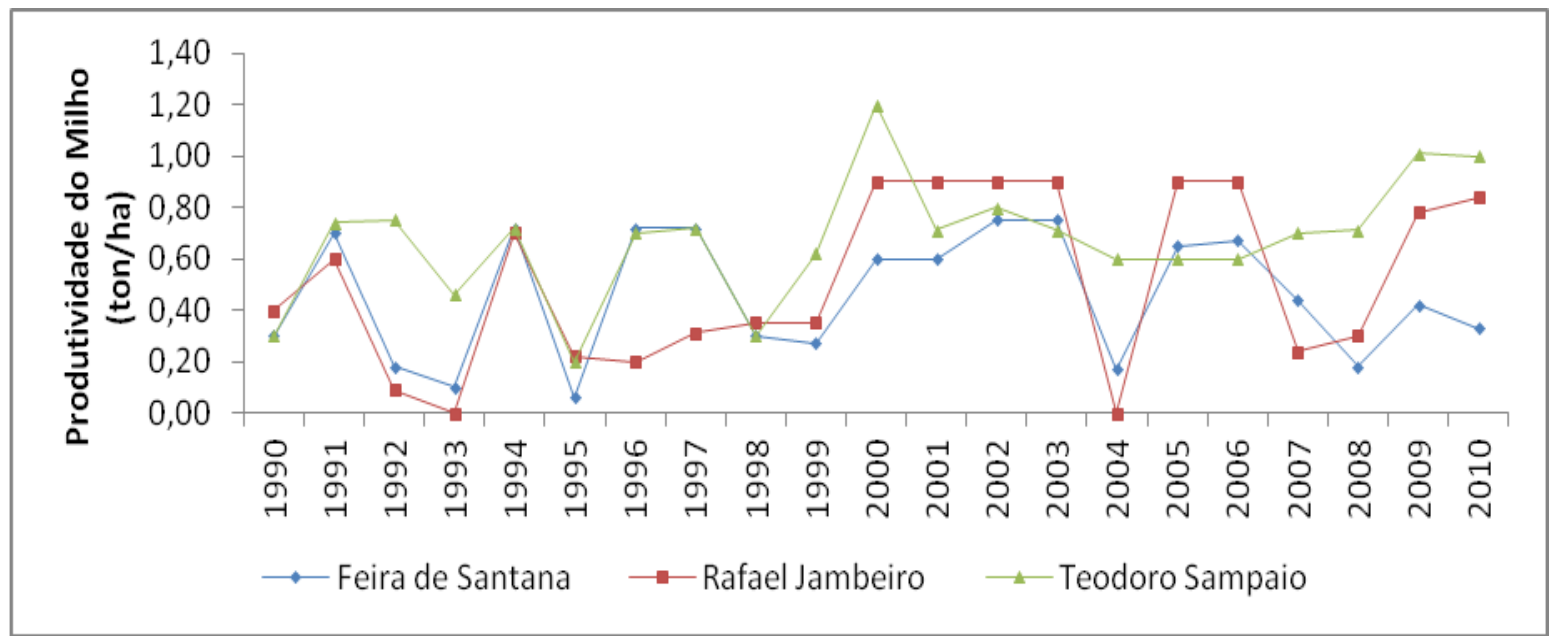

Figura 48: Dados da produtividade (ton/ha) do cultivo do milho nos municípios de Feira de Santana, Rafael Jambeiro e Teodoro Sampaio no período de 1990 a 2010.

Fonte: PAM, IBGE (2013)

Elaboração: DINIZ (2015)

Ao analisar a Figura 49 que trata dos desvios de chuva e produtividade do milho no município de Teodoro Sampaio é possível perceber que os anos que tiverem os maiores desvios negativos de chuvas tiveram desvios negativos na produtividade do milho, a citar os anos de 1990, 1993 e 1998. Os anos de 1991, 1992, 2001, 2002, 2007 e 2009 se apresentaram com desvios negativos de chuvas, e não apresentaram perdas na produtividade do milho.

O ápice da produtividade foi no ano de 2000, sendo este ano o segundo ano mais chuvoso da série histórica. O ano de 2009 foi um dos mais chuvosos, e apresentou os maiores desvios negativos da produtividade do milho. Isto ressalta a necessidade de compreensão da distribuição das chuvas ao longo do ano agrícola (Figura 49). 


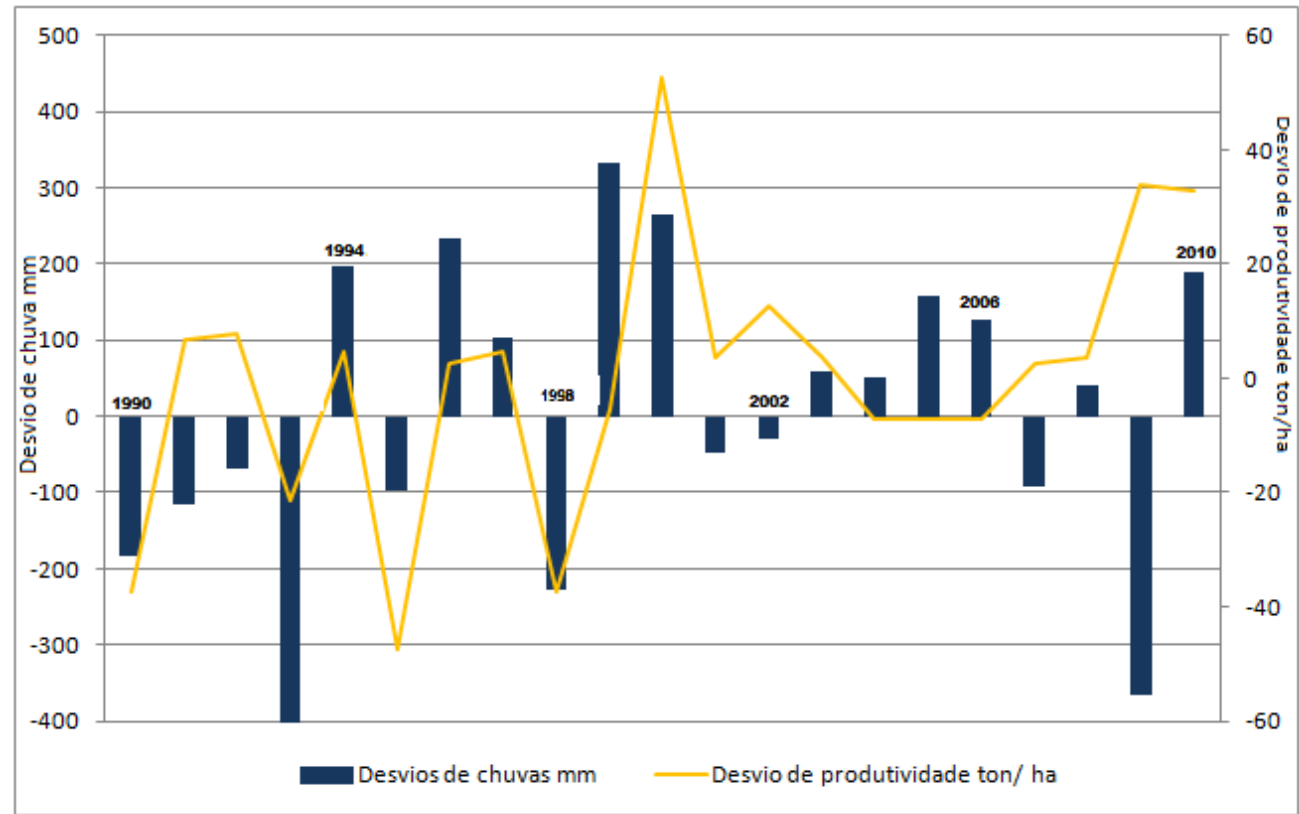

Figura 49: Desvios de chuva e produtividade do milho no município de Teodoro Sampaio (Bahia) no período de 1990 a 2010.

Fonte dos dados: ANA (2013) e IBGE (2013).

Na Figura 50 o ano de 1995 no município de Feira de Santana apresentou o segundo maior desvio negativo de chuva, e teve o maior desvio negativo na produtividade. Os anos de 1996 e 1997 apresentaram maiores volumes de chuvas na série histórica, e tiveram ganhos na produtividade do milho, apresentando uma relação direta entre a distribuição das chuvas e a produtividade do milho.

Os anos de 1999, 2008 e 2010 tiveram desvios negativos na produtividade, mas não tiveram desvios negativos nas chuvas. Por sua vez, os anos de 2001, 2002 e 2006 tiveram desvios negativos das chuvas, mas não tiveram desvios negativos na produtividade do milho na série histórica em estudo (Figura 50). 


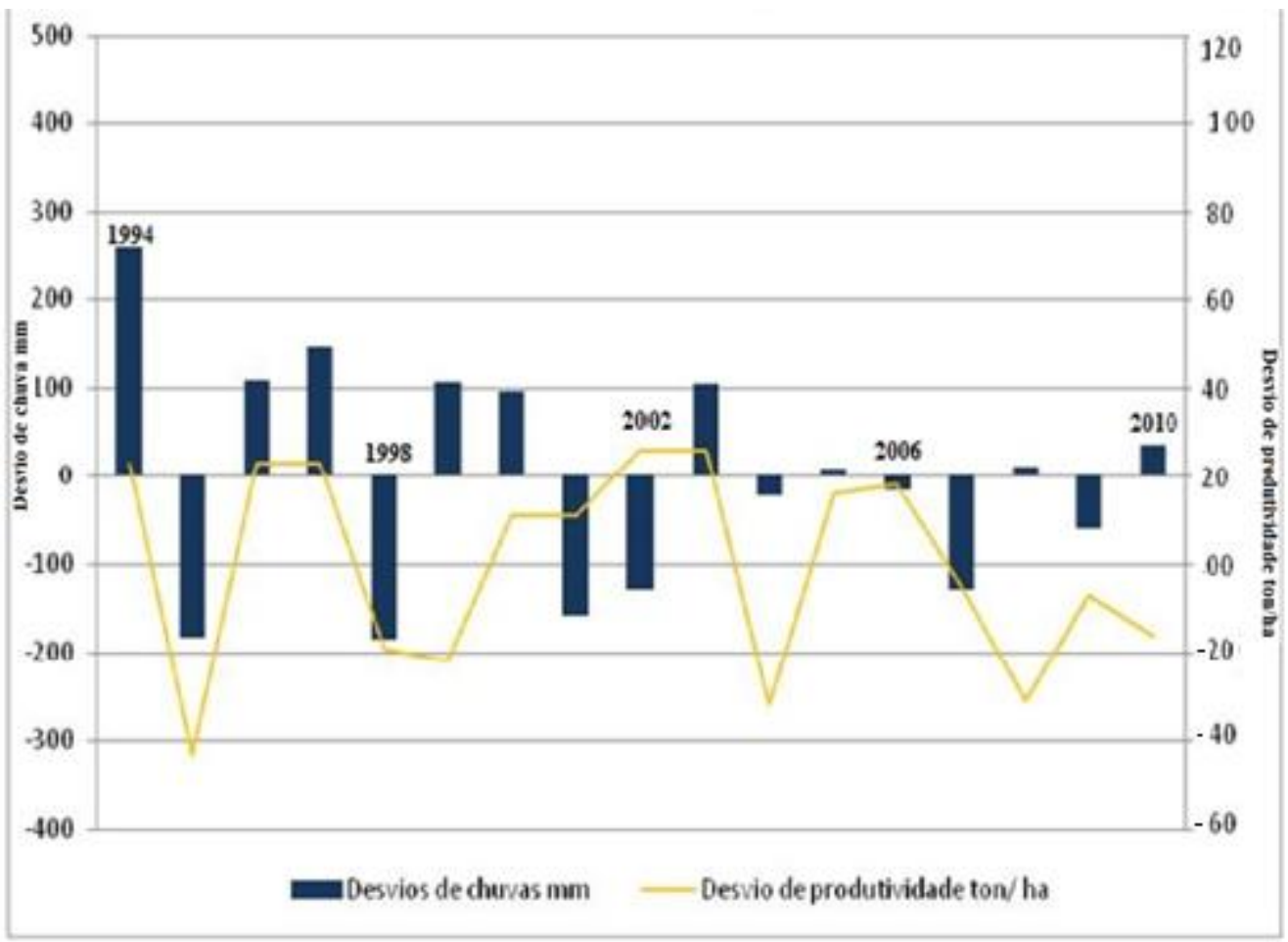

Figura 50: Desvios de chuva e produtividade do milho no município de Feira de Santana (Bahia) no período de 1994 a 2010.

Fonte dos dados: Estação Climatológica/ UEFS (2013) e IBGE (2013).

A Figura 51 retrata os desvios de chuvas e produtividade do milho no município de Rafael Jambeiro é possível observar que o ano de 1993 apresentou os maiores desvios negativo de chuva e de produtividade do milho, respectivamente. O ano de 2003 apresentou o segundo maior desvio de pluviosidade, porém não teve perdas na produtividade do milho.

Os anos de 1991, 1994. 2003, 2004, 2009 e 2010 tiveram desvios negativos das chuvas, mas não tiveram desvios negativos na produtividade do milho na série histórica em estudo. Os anos 1992, 1995, 1997, 1999, 2004, 2007 e 2008 tiveram desvios negativos na produtividade, mas não tiveram desvios negativos nas chuvas (Figura 51). 


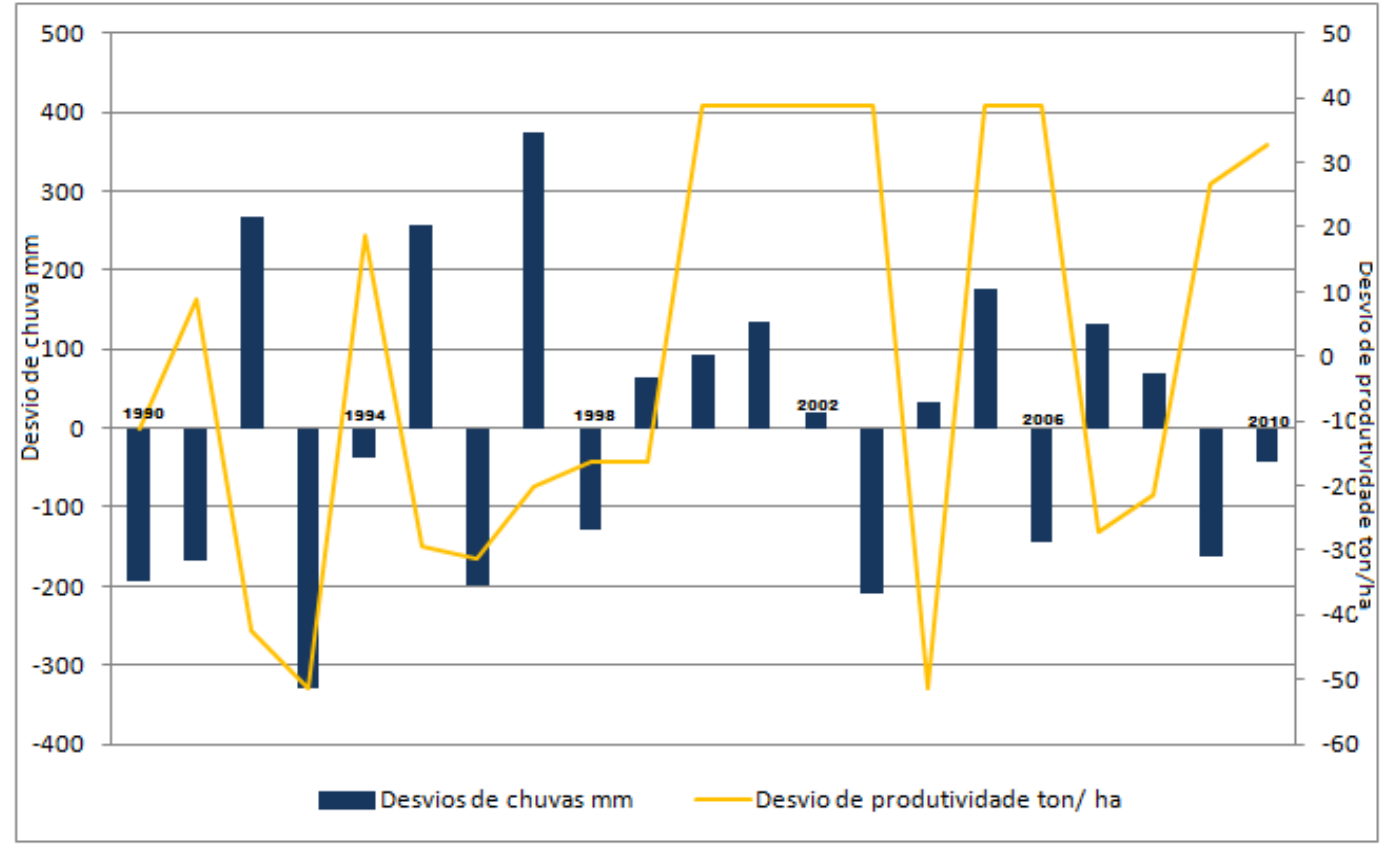

Figura 51: Desvios de chuva e produtividade do milho no município de Rafael Jambeiro (Bahia) no período de 1990 a 2010.

Fonte dos dados: ANA (2013) e IBGE (2013).

As Figuras 52 a 54 tratam-se da correlação dos desvios de chuva e produtividade do milho nos municípios em estudo. É possível notar que as correlações não são significativas nos três municípios. Nas Figuras 52 e 53 os municípios de Teodoro Sampaio e Feira de Santana apresentam-se com melhores distribuições das chuvas e, portanto, melhor correlação entre os dados de pluviosidade e produtividade do milho. Na Figura 54, trata-se do município de Rafael Jambeiro, que apresenta maior irregularidade das chuvas e menor correlação entre as variáveis em estudo. 


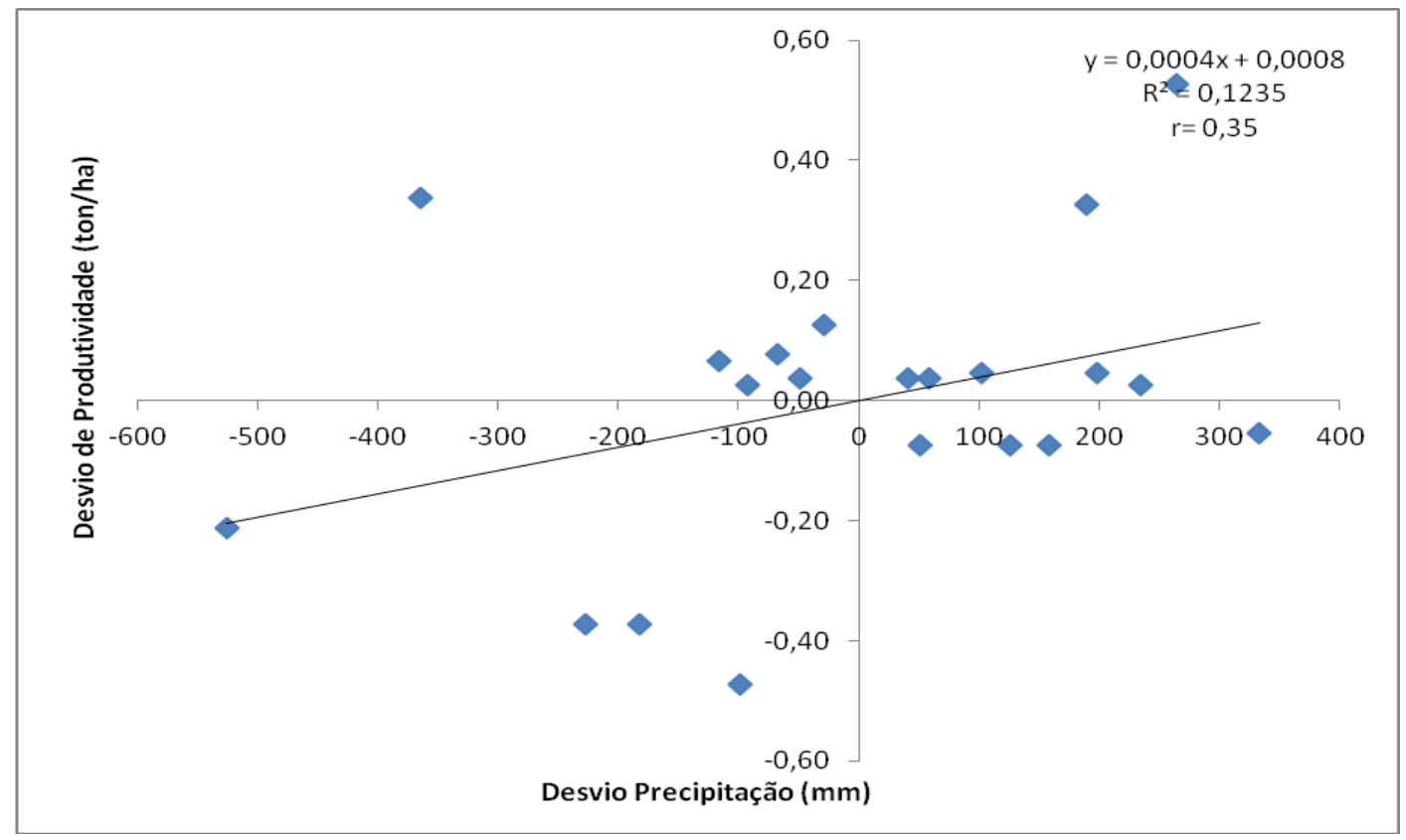

Figura 52: Correlação dos desvios de chuva e produtividade do milho no município de Teodoro Sampaio (Bahia) no período de 1990 a 2010.

Fonte dos dados: ANA (2013) e IBGE (2013).

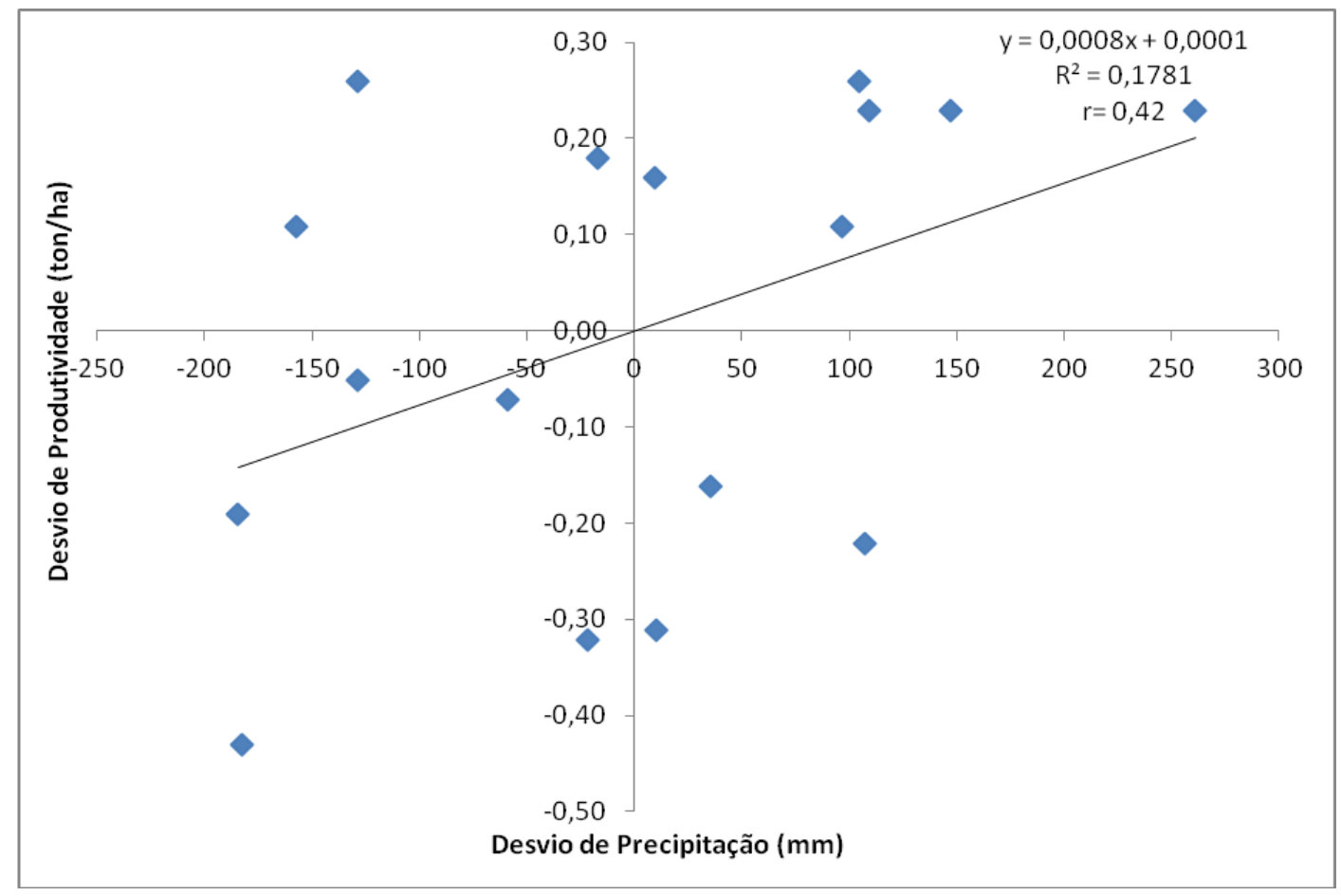

Figura 53: Desvios de chuva e produtividade do milho no município de Feira de Santana (Bahia) no período de 1994 a 2010.

Fonte dos dados: ANA (2013) e IBGE (2013). 


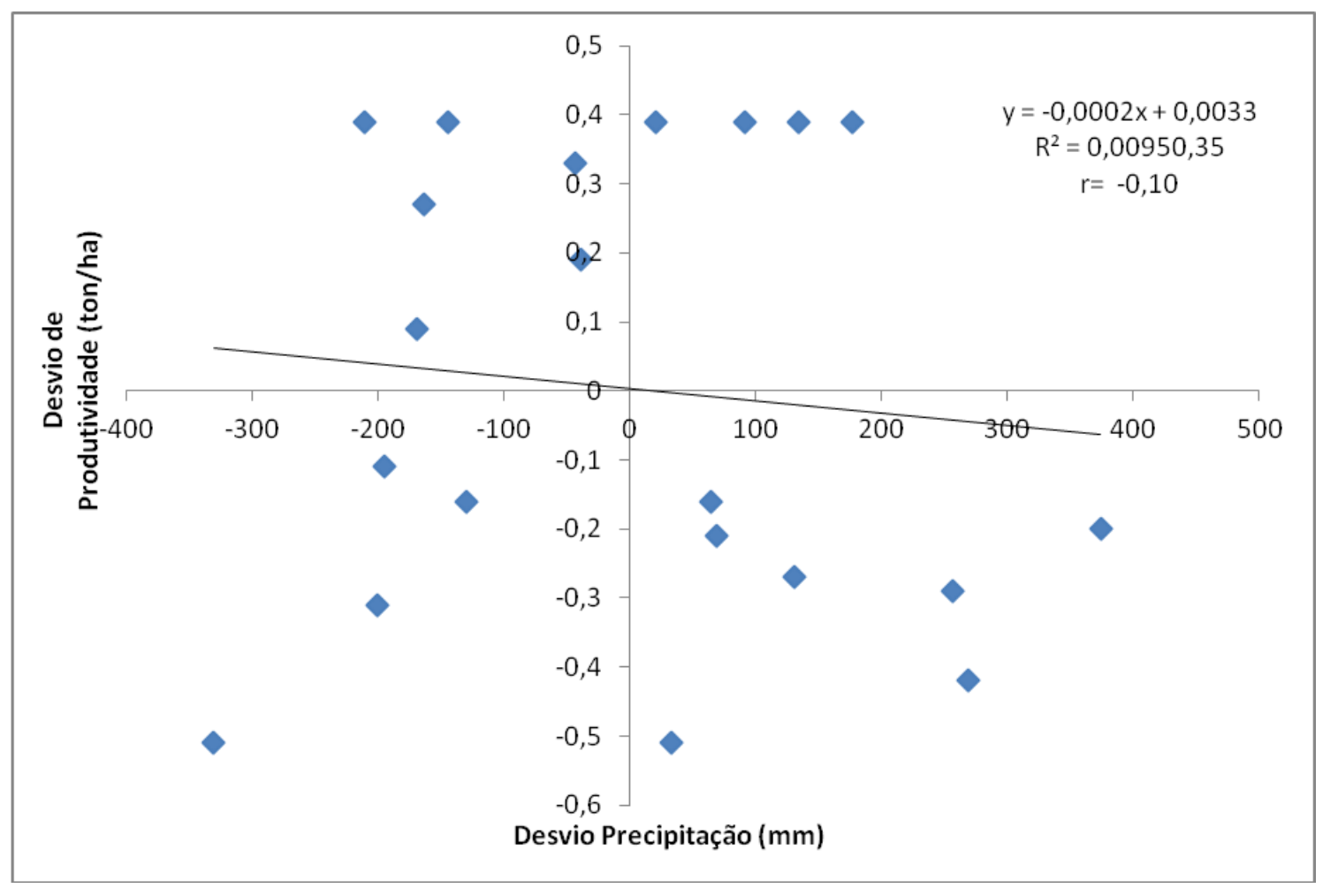

Figura 54: Desvios de chuva e produtividade do milho no município de Rafael Jambeiro (Bahia) no período de 1990 a 2010.

Fonte dos dados: ANA (2013) e IBGE (2013).

De acordo com as Figuras 55 a 57 é possível observar características em comum nos três municípios, como por exemplo, não houve nenhuma situação de excedente hídrico para os municípios em estudo. O mês de junho não apresentou deficiência hídrica anual nos municípios de Teodoro Sampaio e Feira de Santana.

É valido ressaltar, as palavras esclarecedoras de Cavalcanti et al. (2009) quando ditas sobre os distúrbios de leste. Assim, para a área de estudo a precipitação mensal de junho foi justificada pela propagação de aglomerados de nuvens para oeste e pelos remanescentes de Sistemas Frontais (SFs) que se deslocam sobre os municípios sem a deficiência hídrica anual, o que pode ser facilitado pela componente meridional do escoamento típico de inverno. 


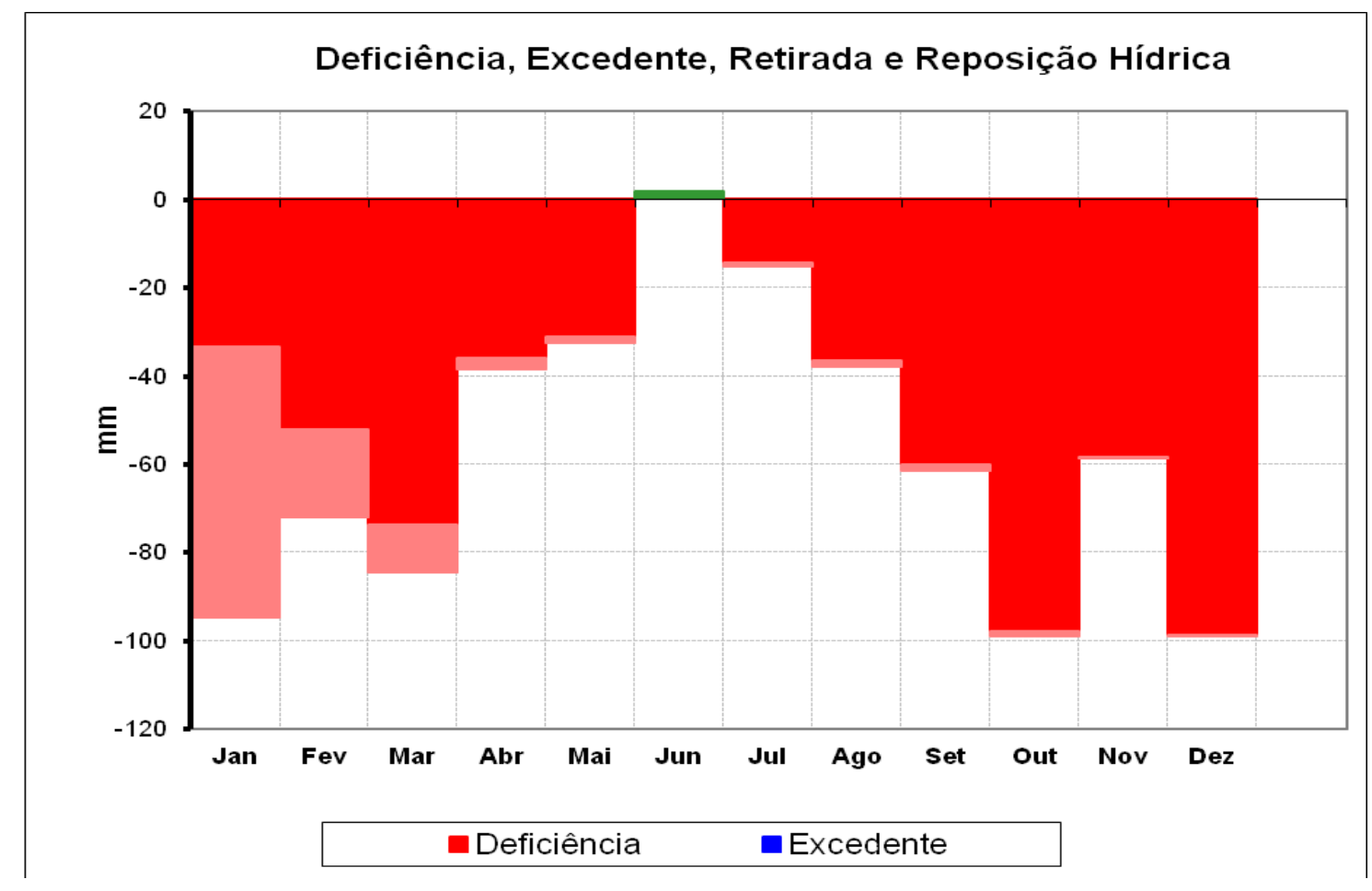

Figura 55: Deficiência, excedente, retirada e reposição hídrica (Thornthwaite, 1948) no município de Teodoro Sampaio (Bahia) no período entre 1990 a 2010.

Fonte: ANA (2013)

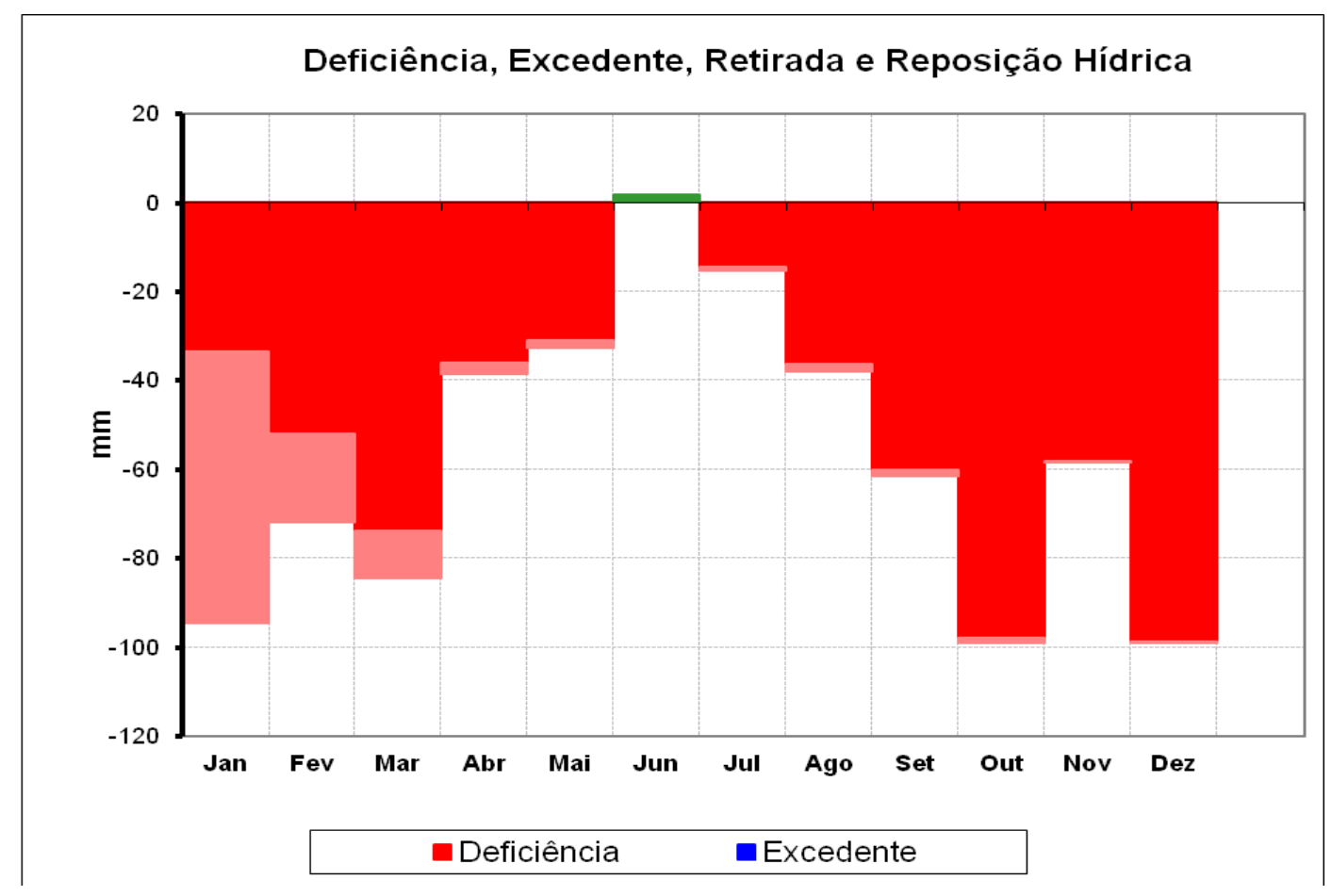

Figura 56: Deficiência, excedente, retirada e reposição hídrica (Thornthwaite, 1948) no município de Feira de Santana (Bahia) no período entre 1994 a 2010.

Fonte: Estação Climatológica, UEFS (2012) 


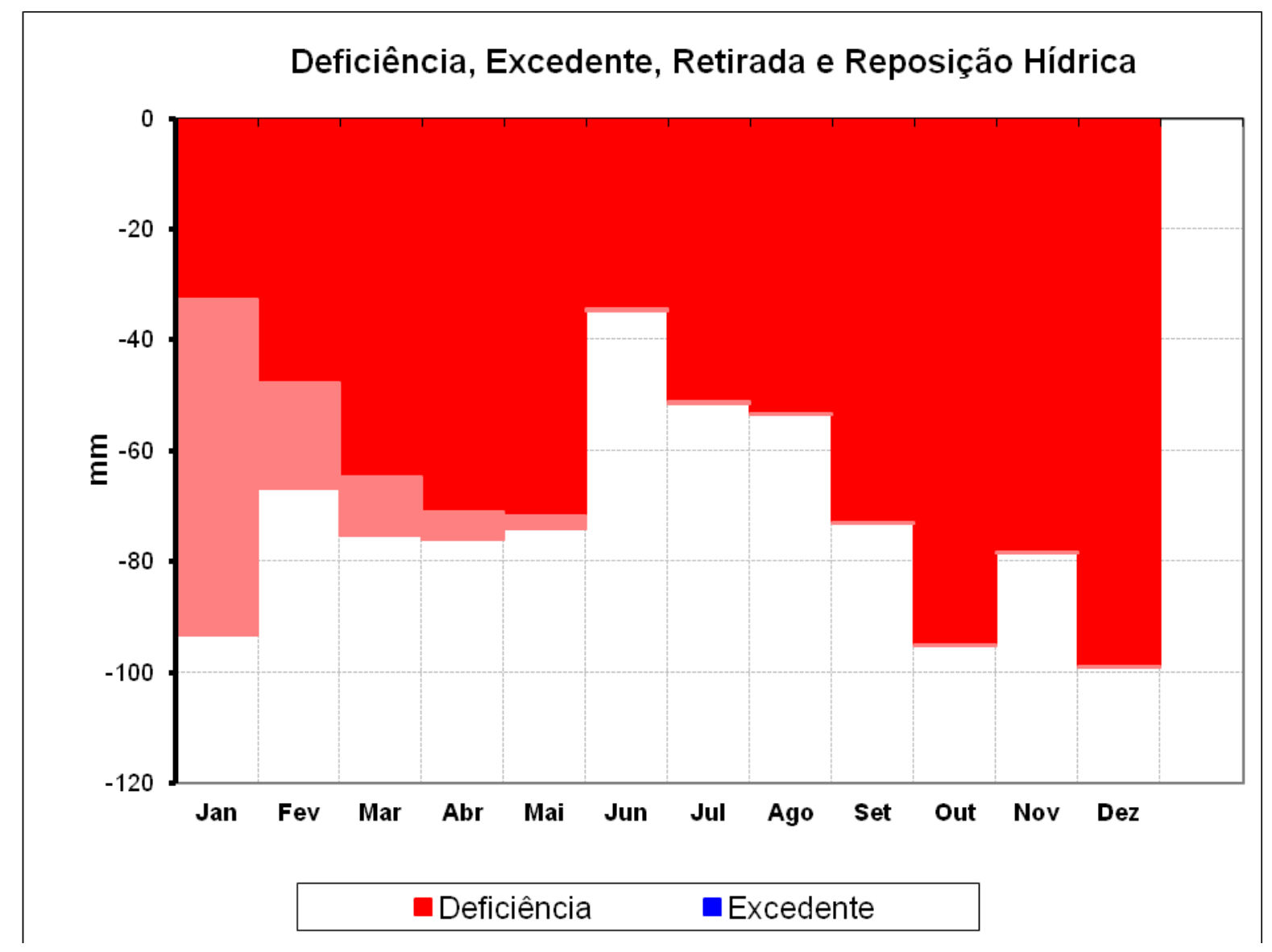

Figura 57: Deficiência, excedente, retirada e reposição hídrica (Thornthwaite, 1948) no município de Rafael Jambeiro (Bahia) no período entre 1990 a 2010.

Fonte: ANA (2013) 


\section{CONSIDERAÇÕES FINAIS}

Em vias de conclusão, é importante ressaltar que os objetivos propostos desta pesquisa foram alcançados. O objetivo geral que foi estudar a relação entre a precipitação pluviométrica na microrregião de Feira de Santana, no período entre 1990 a 2010, e seus reflexos na cultura do milho, identificando as correlações entre a chuva e a produtividade agrícola, sendo este alcançado, uma vez que, foi possível realizar correlações entre precipitação pluviométrica, produtividade do milho e a atuação de alguns sistemas de circulação atmosférica como os Sistemas Frontais, influência da corrente perturbada de leste e o fenômeno El Niño-Oscilação Sul (ENOS), ficando bastante claro a sua interferência na produtividade agrícola do milho.

A hipótese levantada para este trabalho foi se na Microrregião de Feira Santana a precipitação pluviométrica no período entre 1990 e 2010 define a produtividade do milho. Desta forma, em vias de conclusão é importante citar que a variabilidade das chuvas, devido à atuação dos sistemas de circulação atmosférica interfere na produtividade agrícola.

Foi possível perceber dentro da série histórica que alguns anos apresentaram uma relação direta entre os desvios de chuvas com a produtividade do milho, ficando bastante claro que alguns desvios negativos de chuvas foram coincidentes com os desvios negativos de produtividade, porém a correlação entre os desvios de precipitação e produtividade do milho realizada para os três municípios foi pouca significativa. 


\section{REFERÊNCIAS BIBLIOGRÁFICAS}

ABRAMOVAY, R. Paradigmas do capitalismo agrário em questão. Campinas: Editora da UNICAMP, 1998.

ALVES, J. História das Secas no século XVII a XIX. Ceará: Coleção Instituto do Ceará, Fundação Waldemar Alcântara, 2003.

ANJOS, N. F. R.; BASTOS, C. A. M. Estudo sobre as possibilidades hidrogeológicas de Feira de Santana. SUDENE: 1968.

AOUAD, M. dos S. Riscos de Seca e Graus de Severidade do Semi-árido no Estado da Bahia. Salvador: Centro de Estatística e Informações, 1991.

. Tentativa de classificação climática para o Estado da Bahia. Rio de Janeiro: IBGE, 1983.

ARAGÃO, J. O. R. de. A previsão da precipitação no norte do Nordeste do Brasil para o período chuvoso de fevereiro a maio: os anos 1997/98. In: MENEZES, A. V. C. de; PINTO, J. E. S. de S. Geografia: 2011. Sergipe: NPGEO/UFS, 2000.

AYALA-OSUNA, J. T. Genética e Melhoramento do milho tropical: propostas para aumentar a produtividade. Feira de Santana: Universidade Estadual de Feira de Santana, 2001.

AYOADE, J. O. Introdução à Climatologia para os Trópicos. São Paulo: Bertrand Brasil, 1983.

BARBOSA, D. V. N. Os impactos da seca de 1993 no semi-árido baiano: o caso de Irecê. Salvador: SEI, 2000. 
BRUM, A. J. Modernização da Agricultura: Trigo e Soja, Petrópolis: Vozes, 1988.

BURMAN, G.; NAVARRO, L. M. Estimativas das safras agrícolas no Estado da Bahia. Bahia: Análise \& Dados. Salvador, CEI, v. II, n. 1, p. 45-48, jun, 1992.

CALVACANTI, I. F. de A.; FERREIRA, N. J.; SILVA, M. G. A. J.; DIAS, M. A . F. da S. Tempo e Clima no Brasil. São Paulo: Oficina de Textos, 2009.

CARVALHO, B. C. L. de. A produção de milho na Bahia. Bahia: Análise \& Dados. Salvador, CEI, v. II, n. 1, p. 121-122, jun, 1992.

CARVALHO, C. D. de. Météorologie du Brésil. Londres: John Bale, Sons \& Danielson, 1917.

CARVALHO, L. C. P. Aspectos geoeconômicos da produção do milho. São Paulo: USP, 1967.

CAVIEDES, C. N. El Niño 1972: It's climatic ecological, human, and economic implications. Geog. Rev., 65: 493-509, 1975.

CENTRO DE PREVISÃO DO TEMPO E ESTUDOS CLIMÁTICOS (CPTEC). Disponível em http://enos.cptec.inpe.br/. Acesso em 23 de maio de 2012.

CHRISTOFIDIS, D. A água e a crise alimentar. 1997. Disponível em http://www.iica.org.br. Acesso em 27 de junho de 2012.

CHRISTOFOLETTI, A. Das bases meteorológicas à climatologia aplicada. Geografia, Rio Claro, v.14, n.28, p. 142-154, out., 1989.

- Implicações geográficas relacionadas com mudanças climáticas. Boletim de Geografia Teorética. v. 23, n. 45-46, p. 18-31, 1993. 
COELHO, A. M; MORAIS, A. R. de; GAMA, E. E. G.; SILVA, B. G. da; CORNÉLIOS, W. M. de O. Estimativa da estabilidade de produção em cultivares de milho para o estado de Minas Gerais. Pesquisa Agropecuária. Brasileira, Brasília, set., 1988.

COMPANHIA NACIONAL DE ABASTECIMENTO. Calendário Agrícola. Disponível em http://www.conab.gov.br/conteudos.php?a=1125\&t=2. Acesso em 23 de mai. de 2012.

CURRY, L. Climate and economic life: a new approach. The Geographical Review, p. 367-383, 1952.

DINIZ, J. A. F. Geografia da Agricultura. São Paulo: DIFEL, 1984.

EMPRESA BRASILEIRA DE PESQUISA AGROPECUÁRIA. Sistema Brasileiro de Classificação de Solos. Brasília: EMBRAPA, 1999.

FANCELLI, A. L.; LIMA, U. A. Milho: Produção, pré-processamento e transformação agroindustrial. SICCI/PROMOCET/FEALQ. São Paulo, 1982. (Série Extensão Agroindustrial, 05).

FERRAZ, J. de S. Causas prováveis das secas do Nordeste Brasileiro. Rio de Janeiro: Ed. da Diretoria de Meteorologia, 1925.

FREITAS, N. B. Urbanização e modernização industrial das cidades médias da Bahia: um olhar sobre Feira de Santana. In: SUPERINTENDÊNCIA DE ESTUDOS ECONÔMICOS E SOCIAIS DA BAHIA. Cidades médias e pequenas: teorias, conceitos e estudos de caso. Salvador: SEI, 2010.

GONÇALVES, N. M. S. Impactos pluviais e desorganização do espaço urbano em Salvador - BA. 1992. 268 p. Tese (Doutorado) - Programa de Pós-Graduação em Geografia Física, Faculdade de Filosofia, Letras e Ciências Humanas, Universidade de São Paulo, São Paulo, 1992. 
GOODMAN, M. M.; SMITH, J. S. C. Botânica. In: PATERNIANI, E. Melhoramento e produção do milho. Campinas: Fundação Cargill, 1987.

HATTERSLEY, P. W. Characterization of C4 type leaf anatomy in grasses (Poaceae). Mesophyll: bundles sheath area ratios. Annual of Botany, v. 53, p. 163-179, 1984.

INSTITUTO BRASILEIRO DE GEOGRAFIA E ESTATÍSTICA. Disponível em http://www.sidra.ibge.gov.br/bda/tabela/protabl.asp?z=t\&o=11\&i=P. Acesso em 13 de mai. 2012.

JESUS, E. F. R. Algumas considerações a respeito das mudanças climáticas atuais. Boletim de Geografia Teorética, São Paulo, v. 21, n. 41, p. 45-60, set./dez. 1991.

Algumas reflexões teórico-conceituais na climatologia geográfica em mesoescala: uma proposta de investigação. GeoTextos, vol. 4, n . 1 e 2, p. 165-187, 2008.

KAYANO, M. T. Low-level high-frequency modes in the Tropical Atlantic and their relation to precipitation in the equatorial South. Meteor. Atmos. Phys., v.83, p. 263-276, 2003.

KAISER, W. M. Effect of water deficit on photosynthetic capacity. Physiol. Plant., v.71, p.142-149, 1987.

KOUSKY, V. E. Diurnal rainfall variation in Northeast Brazil. Monthly Weather Review, v. 108, n. 4, p. 488-498, 1980.

. Frontal Influences on Northeast Brazil. Monthly Weather Review, v. 107, n. 9, p. 1140-1153, 1979. 
MAIA, D. C. Variabilidade climática e a produtividade do milho em espaços paulistas. Dissertação (Mestrado). UNESP, 2003.

MANOSSO, F. C. A produtividade de soja, trigo e milho e suas relações com a precipitação pluviométrica no município de Apucarana-PR no período de 1968 a 2002. Paraná: Revista do Departamento de Geociências v. 14, n. 1, jan./jun. 2005.

MARENGO, J. A. Vulnerabilidade, impactos e adaptação à mudança do clima no semi-árido do Brasil. Parcerias Estratégicas, Brasília, oㅡ 27, dezembro, 2008.

MINISTÉRIO DA AGRICULTURA. Produção do milho. http://www.agricultura.gov.br. Acesso em 01 de agosto de 2012.

Zoneamento agrícola do Estado da Bahia: aptidão pedoclimática por cultura. Salvador: Secretaria Nacional de Planejamento Agrícola, 1985.

MONTEIRO, C. A. de F. Fatores climáticos na organização da agricultura nos países tropicais em desenvolvimento. São Paulo: Universidade de São Paulo, Climatologia, ํo 10, oo 10, p. 01-36, 1981.

O clima e a organização do espaço no Estado de São Paulo: Problemas e perspectivas. São Paulo: IGEOG/USP, 1976.

O estudo geográfico do clima. In: Cadernos Geográficos, n. 1, Florianópolis: Imprensa Universitária da UFSC, 1999.

MORAES, G. I.; FERREIRA FILHO, J. B. de S. Economia das mudanças climáticas e a agricultura baiana. In: Bahia Análise \& Dados. SUPERINTENDÊNCIA DE ESTUDOS ECONÔMICOS E SOCIAIS DA BAHIA. Salvador, v. 21, n. 4, p. 843-856, out./dez. 2011. 
MORIZE, H. Esboço da climatologia do Brasil. Rio de Janeiro: Observatório Astronômico, 1889.

MOTA, F. S. da. Clima e agricultura no Brasil. Rio Grande do Sul: SAGRA, 1986.

. Meteorologia Agrícola. São Paulo: Nobel, 1983.

NATIONAL DROUGHT MITIGATION CENTER, 1995. Disponível em: http://www.drought.unl.edu/error_files/ndmc_redirect.htm Acesso em 09 de junho de 2012.

NIMER, E. Clima. In: INSTITUTO BRASILEIRO DE GEOGRAFIA E ESTATÍSTICA. Geografia do Brasil: Região Nordeste. Rio de Janeiro, 1977.

. Climatologia do Brasil. Rio de Janeiro: IBGE, Departamento de Recursos Naturais e Estudos Ambientais, 1989.

NUNES, L. H.; LOMBARDO, M. A. A questão da variabilidade climática: uma reflexão crítica. Revista do Instituto Geológico. São Paulo, v. 16, n. 1/2, p. 2131, 1995.

OGALLO, L. A. J. NASSIB, I. R. Drought patterns and famines in East Africa during 1982-1983. In: Simposium on Meteorological Aspects of Tropical Droughts. Fortaleza, 1984. Annals. World Meteorological Organization, 1984.

PEREIRA, A. R.; ANGELOCCI, L. R.; SENTELHAS, P. C. Agrometeorologia: Fundamentos e Aplicações Práticas. Guaíba: Livraria e Editora Agropecuária, 2002.

PINTO, J. E. S. de S. Os reflexos da seca no estado de Sergipe. São Cristovão: NPGEO, UFS, 1997. 
POPPINO, R. Feira de Santana. Salvador: Editora Itapuã, 1968.

RIBEIRO, A. G. Climatologia geográfica e a organização do espaço agrário. In: Boletim de Geografia Teorética. Rio Claro: AGETEC, 1993. v. 23, n.45-46, p.34-38.

SANT'ANNA NETO, J. L. Clima e Organização do Espaço. Boletim de Geografia, Maringá, v. 16, p. 119-131, 1998.

- História da Climatologia no Brasil: gênese e paradigmas do clima como fenômeno geográfico. Cadernos Geográficos - publicação do Departamento de Geociências - CFH/ UFSC, Florianópolis, SC, n. 7, 124p., maio, 2003. ISSN 1519-4639.

SANT'ANNA NETO, J. L.; RIGATTI, N.; GROSSO, C.; DAMASCENO, A.; VALIO, D. A.; GOULART, H. R. Análise da variabilidade das chuvas no Extremo Oeste Paulista (1971-1999). In: V Simpósio Brasileiro de Climatologia Geográfica, Curitiba, 2002.

SANTO, S. M. A água em Feira de Santana: uma analise do bairro Rocinha. 1995. Dissertação (Mestrado), FAU/UFBA. Salvador, 1995.

SANTOS, J. A. L. dos. Implicações do Pronaf na produção do espaço rural do município de Feira de Santana-BA (1999/2006). Dissertação (Mestrado em Geografia) - Instituto de Geociências. Universidade Federal da Bahia, Salvador, 2007.

SANTOS, M. A seca social: a velha trilogia dramática (seca, fome e êxodo). Carta Capital, 27/05/1998, p. 60-62. 
SANTOS, M. J. Z. dos. Mudanças climáticas e a relação com a produção agrícola. Boletim Climatológico, Presidente Prudente, v. 1, n. 2, p. 51-60, 1996.

- Mudanças climáticas e o planejamento agrícola. In: SANT'ANNA NETO, J. L.; ZAVATINI, J. A. Variabilidade e mudanças climáticas. Maringá: Editora da EDUEM, 2000, p. 65-80.

. Mudanças climáticas no Estado de São Paulo. Geografia, Rio Claro, v. 21, n. 2 , p. 111-171, 1996.

SCHUSSLER, J. R.; WESTGATE, M. E. Maize kernal set at low water potential. Sensitivity to reduced assimilates during early kernal growth. Crop Science, Madison, v.31, p.1189-1195, 1991.

SECRETARIA DE AGRICULTURA, IRRIGAÇÃO E REFORMA AGRÁRIA. A primeira safra de grãos de 2002 na Bahia. Bahia Agrícola. Salvador, SEAGRI, v. 05 , n. 01 , set., 2002.

. Grãos: bons resultados na $2^{\mathrm{a}}$ safra de milho e feijão de sequeiros.

Bahia Agrícola. Salvador, SEAGRI, v. 02, n. 03, nov., 1998.

. Grãos: situação e tendências dos principais produtos. Bahia Agrícola.

Salvador, SEAGRI, v. 01, n. 03, fev., 1997.

SECRETARIA DE PLANEJAMENTO, CIÊNCIA E TECNOLOGIA. Atlas Climatológico do Estado da Bahia: o clima como recurso natural básico à organização do espaço geográfico. Salvador: Centro de Planejamento da Bahia (CEPLAB), 1978 (documento síntese).

SETZER, J. A distribuição normal das chuvas no Estado de São Paulo. Revista Brasileira de Geografia, ano VIII, n. 1, p. 3-70, 1946. 
SILVA, C. P. da. O problema do Nordeste: as secas. Rio de Janeiro: Livraria Francisco Alves, 1920.

SOUSA, R. R.; TOLEDO, L. G.; TOPANOTTI, D. Q. Oscilação das chuvas na porção Centro Oeste do estado de Mato Grosso, entre os anos de 1996 a 2001. Goiânia: Boletim Goiano de Geografia, v. 27, n. 3, p. 71-89, jul/dez, 2007.

SOUZA, I. A. A avaliação dos impactos provocados pelo El Niño em algumas culturas no estado de Pernambuco. In: Congresso Brasileiro de Agrometeorologia, 1999. Florianópolis (SC). Anais. Florianópolis, 1999, CDROM.

SUPERINTENDÊNCIA DE ESTUDOS ECONÔMICOS E SOCIAIS DA BAHIA. Análise dos atributos climáticos do Estado da Bahia. Salvador: SEI, 1998.

. Balanço hídrico do Estado da Bahia. Salvador: SEI, 1999.

Índice rural territorial. In: MINISTÉRIO DO DESENVOLVIMENTO AGRÁRIO. Desenvolvimento territorial na Bahia. Brasília, DF. MDA; Salvador: SEI, 2005.

SUPERINTENDÊNCIA DO DESENVOLVIMENTO DO NORDESTE. As Secas do Nordeste: uma abordagem histórica de causa e efeito. Recife: SUDENE, 1981.

TAVARES, A. C. Mudanças climáticas. In: VITTE, A. C.; GUERRA, A. J. T. (Org.). Reflexões sobre a Geografia Física no Brasil. Rio de Janeiro: Bertrand Brasil, 2004.

THORNTHWAITE, C. W.; MATHER, J. R. The water balance. New Jersey: Centerton, 1955. 
THORNTHWAITE, C. W. New approach toward a rational classification of climate. Geographical Review, v.38, n. 1, p. 55-94, 1948.

TUBELIS, A. A chuva e a produção agrícola. São Paulo: Nobel, 1988.

TUCCI, C. E. M.; BRAGA, B. Clima e Recursos Hídricos no Brasil. Coleção ABRH de Recursos Hídricos, v. 9, 2003.

UNE, M. Y. Fatores climáticos influenciando a agricultura em Campo Grande (MT). Revista Brasileira de Geografia, v. 41, n. 1 e 2, p. 03-31, 1979. 